\title{
REVISTA
}

\section{SOL DE AQUINO}

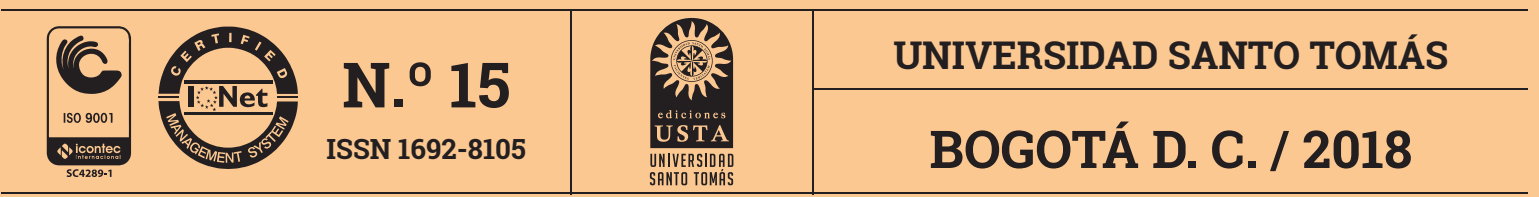

Humanismo

y desarrollo.

Por una

perspectiva

humanista de la

planeación para

el desarrollo

Pág. 15
La danza

en la tragedia

griega clásica

Pág. 42
Educación

intercultural

bilingüe: retos

por asumir

y acciones

concretas

por realizar

Pág. 50
(Re)construir

identidad

y resignificarse

culturalmente:

una ambición para

el hombre muisca

contemporáneo

de Bosa

Pág. 57

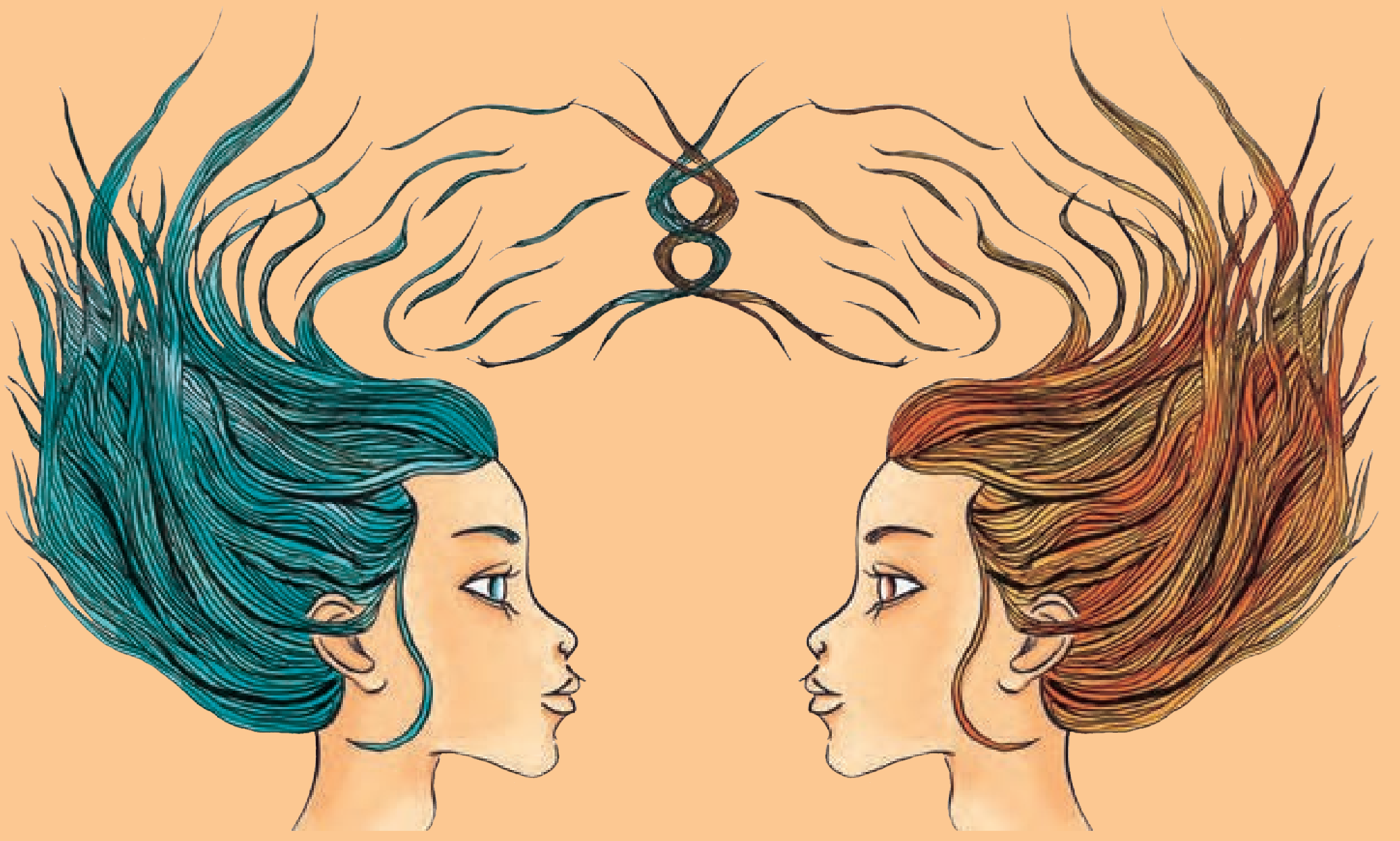




\section{REVISTA}
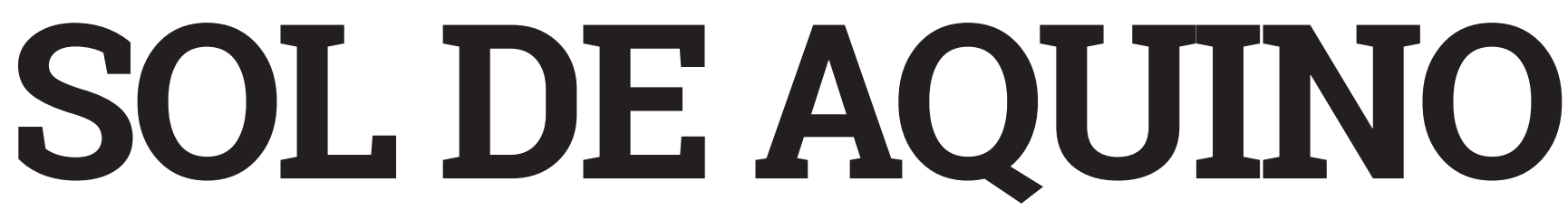

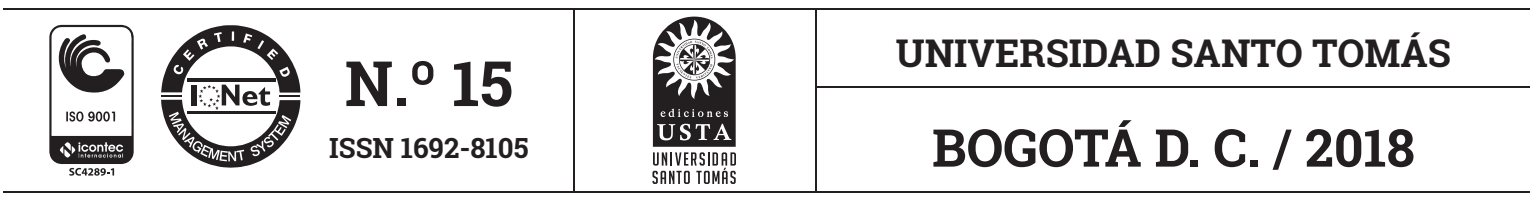




\section{CONSEJO DE FUNDADORES}

Fray Said LEÓN AMAYA, O. P. - Prior Provincial y Presidente del Consejo de Fundadores de la USTA

Fray J uan Ubaldo LÓPEZ SALAMANCA, O. P. - Rector General Universidad Santo Tomás Fray J osé Arturo RESTREPO RESTREPO, O. P. - Consejero

Fray J osé Antonio GONZÁLEZ CORREDOR, O. P. - Secretario

Fray J aime MONSALVE TRUJ ILLO, O. P. - Consejero

Fray Franklin BUTTRAGO ROJAS, O. P. - Consejero

\section{CONSEJO SUPERIOR}

Fray Juan Ubaldo LÓPEZ SALAMANCA, O. P. - Rector General

Fray Mauricio Antonio CORTÉS GALLEGO, O. P. - Vicerrector Académico General

Fray Luis Francisco SASTOQUE POVEDA, O. P. - Vicerrector Administrativo- Financiero Genera

Fray Tiberio POLANÍA RAMÍREZ, O. P. - Vicerrector General Universidad Abierta y a Distancia

Fray Érico J uan MACCHI CÉSPEDES, O. P. - Rector Seccional Bucaramanga

Fray J orge Ferdinando RODRÍGUEZ RUIZ, O. P. - Rector Seccional Tunja

Fray Alberto René RAMÍREZ TÉLLEZ, O. P. - Representante de los Decanos de División (Bogotá)

María Ligia Herrera Navarro - Representante de los decanos de Facultad (Bogotá)

Germán Enrique Patiño Plata - Representante de los docentes (Seccional Bucaramanga)

July Paola Becerra Sánchez - Representante de los estudiantes (VUAD)

Cindy Zarella Hernández Bernal - Representante de los egresados (Tunja)

Héctor Fabio J aramillo Santamaría - Secretario General y del Consejo Superior

\section{SECCIONAL BUCARAMANGA}

Fray Érico J uan MACCHI CÉSPEDES, O. P. - Rector

Fray Oscar Eduardo GUAYÁN PERDOMO, O. P. - Vicerrector Académico

Fray J osé Antonio GONZÁLEZ CORREDOR, O. P. - Vicerrector Administrativo

\section{SECCIONAL TUNJA}

Fray J orge Ferdinando RODRÍGUEZ RUIZ, O. P. - Rector

Fray J avier Antonio CASTELLANOS, O. P. - Vicerrector Académico

Fray J osé Antonio BALAGUERA CEPEDA, O. P. - Vicerrector Administrativo

\section{SEDE MEDELLÍN}

Fray Ricardo Ernesto TORRES CASTRO, O. P. - Rector

SEDE VILLAVICENCIO

Fray J osé Arturo RESTREPO RESTREPO, O. P. - Rector

\section{CONSEJO EDITORIAL}

Fray Juan Ubaldo LÓPEZ SALAMANCA, O. P. - Rector General

Fray Mauricio Antonio CORTÉS GALLEGO, O. P. - Vicerrector Académico General

Fray Luis Francisco SASTOOUE POVEDA, O. P. - Vicerrector Administrativo-Financiero General

Fray Tiberio POLANÍA RAMÍREZ, O. P. - Vicerrector General VUAD

Olga Lucía Ostos Ortíz - Directora de la Unidad de Investigación

Esteban Giraldo González - Director de Ediciones USTA

\title{
Revista Sol de Aquino \\ Número 15 - 2018
}

\section{Director}

Fray Mauricio Antonio CORTÉS GALLEGO, O. P.

\section{Editor}

Álvaro Lizarralde Díaz

\section{Director Departamento Editorial}

Esteban Giraldo González

\section{Corrección de estilo}

Juan Carlos Velásquez Sánchez y Luis Daniel Pico Páez

\section{Ilustración de portada}

\author{
Dalieth Méndez
}

\section{Ilustración de páginas internas}

Carlos Arturo Prada J iménez

(Intervención y edición: Sylvana S. Blanco Estrada)

\section{Diagramación}

Sylvana Silvana Blanco Estrada

\section{ISSN: 1692-8105}

Hecho el depósito que establece la ley

\section{@Derechos reservados Universidad Santo Tomás 2018}

\section{Ediciones USTA}

Carrera 9 n. ํ 51-11, Sótano 1

Edificio Luis J. Torres

Tel.: (+571) 5878797, ext.: 2991

editorial@usantotomas.edu.co

www.editorial-usta.edu.co

\section{Publicación editada e impresa en Colombia}




\section{Contenido}

\section{Editorial}

P. 4

\section{Identidades}

La dignificación del ser a través dela experiencia del acontecer

P. 8

Humanismo y desarrollo. Por una perspectiva humanista dela planeación para el desarrollo

P. 15

Misión evangelizadora dela universidad católica P. 22

\section{Caleidoscopio}

El axiologismo neoliberal y su incidencia en el capital social

P. 30

Macroeconomía e inflación en la Guerra de los Mil Días: ¿un asunto litográfico? P. 37

La danza en la tragedia griega clásica

P. 42

\section{Testimonios}

Educación intercultural bilingüe: retos por asumir y aociones concretas por realizar P. 50

(Re)construir identidad $\mathrm{y}$ resignificarse culturalmente: una ambición para el hombremuisca contemporáneo de Bosa P. 57

La cartilla escolar en Rafael Pomboy Walter Benjamin P. 64.

¿Y usted quéheredará alas generaciones que lo preceden?

\section{Invenciones}

Novedadeslibros

P. 76

Novedades revistas científicas

P. 78 


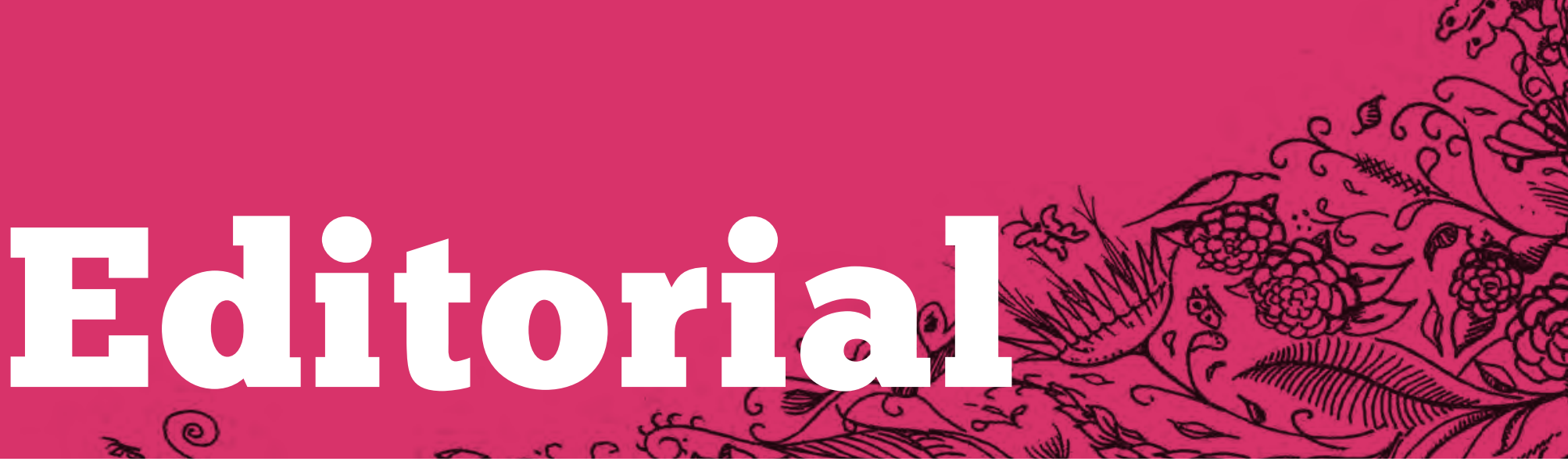

\section{¡Quince ediciones!}

\section{Por Álvaro Lizarralde Díaz Editor}

$\mathbf{N}$ os complace alcanzar la decimaquinta edición de Sol de Aquino con una alforja nutrida de sueños por cumplir, pero también, de satisfacciones por la labor comunicativa que se ha realizado por más de doce años, en pos de la identidad tomasina y de la divulgación de todas las actividades y conocimientos que la Universidad Santo Tomás alienta.

A través de las páginas de nuestra revista, hemos afianzado el compromiso con una filosofía educativa inspirada en el humanismo cristiano, que anima en el hombre, no solo un apetito por saber, sino también por la construcción de sentido y compromiso moral, en el proceso de moldear su ser integralmente.

Desde sus inicios y hasta hoy, la revista se ha estructurado con base en cuatro secciones. La primera - y quizá la más quintaesenciada- , es Identidades, que recoge la filosofía tomista y la forma en que esta se refleja en el proyecto educativo de la Universidad. Los quehaceres y conocimientos del ser humano tienen cabida en la sección Caleidoscopio. Testimonios, por su parte, es el espacio para las experiencias, actividades, eventos, investigaciones, actores y memorias relacionadas con los niveles académico, administrativo y directivo de la Universidad. Finalmente, Invenciones, cuyo interés es visibilizar, a través de breves reseñas, las producciones de distinta índole 


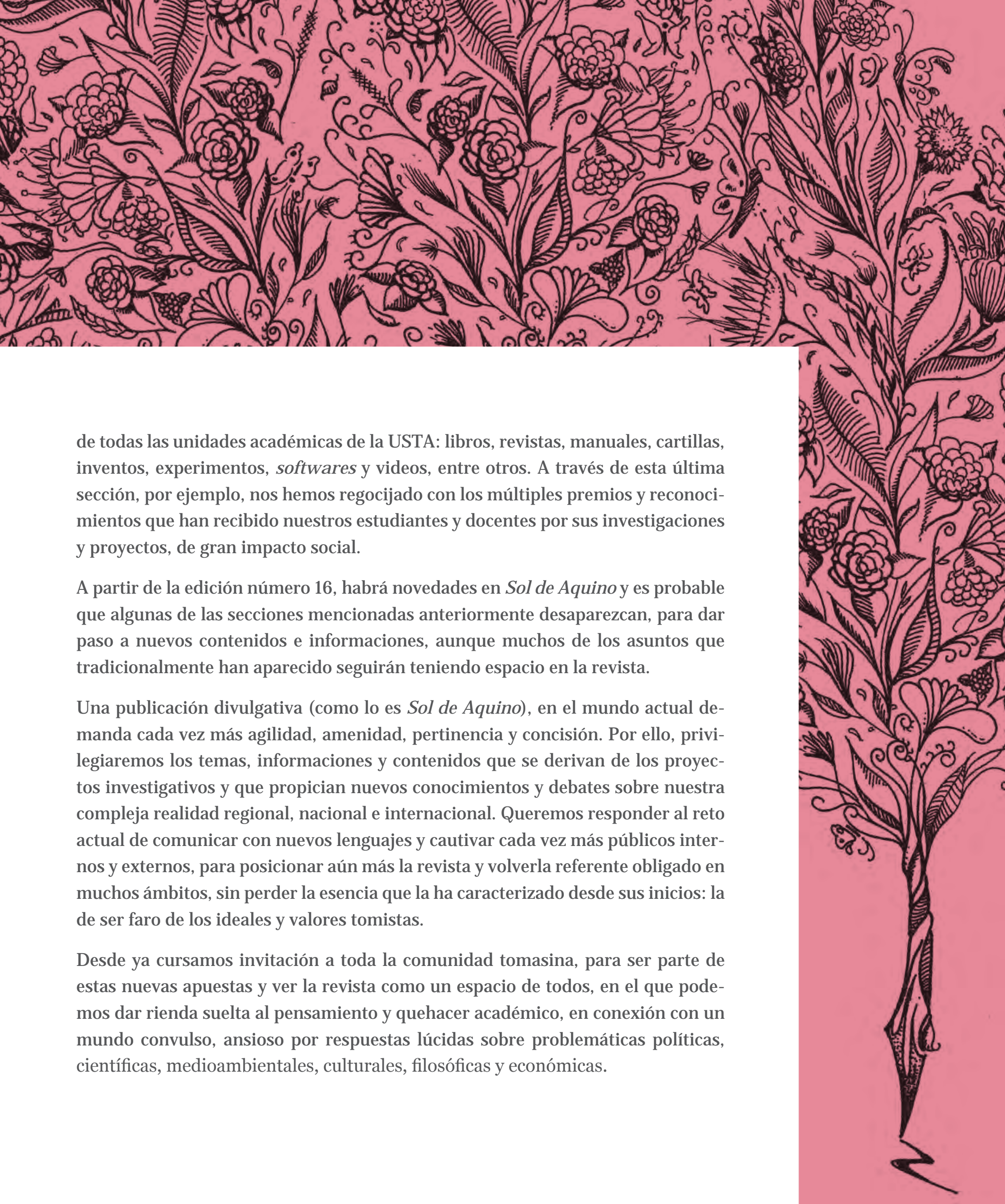

inventos, experimentos, softwares y videos, entre otros. A través de esta última sección, por ejemplo, nos hemos regocijado con los múltiples premios y reconocimientos que han recibido nuestros estudiantes y docentes por sus investigaciones y proyectos, de gran impacto social.

A partir de la edición número 16, habrá novedades en Sol de Aquino y es probable que algunas de las secciones mencionadas anteriormente desaparezcan, para dar paso a nuevos contenidos e informaciones, aunque muchos de los asuntos que

Una publicación divulgativa (como lo es Sol de Aquino), en el mundo actual demanda cada vez más agilidad, amenidad, pertinencia y concisión. Por ello, priviinvestigativos y que propician nuevos conocimientos y debates sobre nuestra actual de comunicar con nuevos lenguajes y cautivar cada vez más publicos internos y externos, para posicionar aun más la revista y volverla referente obligado en muchos ámbitos, sin perder la esencia quela ha caracterizado desde sus inicios: la de ser faro de los ideales y valores tomistas.

Desde ya cursamos invitación a toda la comunidad tomasina, para ser parte de estas nuevas apuestas y ver la revista como un espacio de todos, en el que podemos dar rienda suelta al pensamiento y quehacer académico, en conexión con un

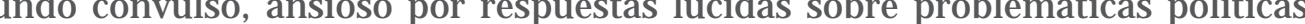
científicas, medioambientales, culturales, filosóficas y económicas. 


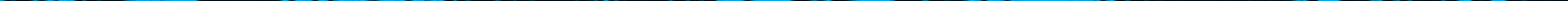




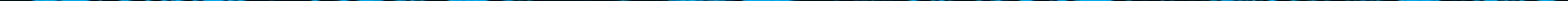


Lo anterior ejemplifica, de manera clara, cómo, desde el propio acontecer, se puede trabajar por el reconocimiento del Ser Persona y su dignificación. El ser humano está en capacidad de elegir ser el mejor en lo que hace. En consecuencia, desde el quehacer por vocación o profesión se tiene la oportunidad y el compromiso ético y moral de forjar buenos seres humanos implicados en el mejoramiento continuo de la sociedad que los circunda. Más allá de enseñar leyes y formas de conceptualizar el mundo, la intención formadora para la vida debe sustentarse en la posibilidad de identificar sus fortalezas y debilidades, de permitir el reconocimiento y redescubrimiento de su Ser Persona, con el ánimo de examinar y consentir su integralidad, significar su existencia y dignificar su Ser. Así, podrá sustentar su actuación de manera sincera y verdadera ante la construcción de una sociedad con óptimos niveles de desarrollo y transformación integral.

Sin duda alguna, otra pregunta que consigue resonar en los oídos, por su significado complejo, en tanto constituye la posibilidad de darle sentido a la reflexión sobre la conducta humana, es esta: ¿Qué podría aportar el autoconocimiento a la realización de un proyecto personal -ético- de vida? El autoconocimiento permite al ser humano redescubrirse, conocer sus potencialidades y falencias, admitir lo importante de su existencia en procura del desarrollo íntegro de las personas que rodean su vida. En esto radicaría el alcance del autoconocimiento como base para la elaboración de un proyecto - ético- de vida. Pues, si el hombre logra reconocerse a sí mismo, puede entonces, de manera clara concebir el significado del existir y cómo ello, influye en la construcción de otras existencias.
Según May (1990) "cuanto mayor es el conocimiento del yo que se posee, mayor es el conocimiento del mundo [...], esta relación inseparable del yo y del mundo implica responsabilidad. No puedo convertirme en un yo, si no me comprometo continuamente respondiendo al mundo del cual soy parte" (De Castro, 2000).

Como bien, plantea Savater (1999), "una vida sin examen, es decir, la vida de quien no sopesa las respuestas que se le ofrecen para las preguntas esenciales, ni trata de responderlas personalmente, no merece la pena de vivirse". Por ello, al ser consciente de sí mismo, se es responsable de la propia vida y por ende de las actuaciones frente al devenir de los otros. Por este motivo no se puede deambular por la vida, sin ser sujetos activos, proactivos y propositivos ante esta, en ello, se sustenta la significación de la existencia y la dignificación del ser. Ser persona responsable, ética y moral, implica un desarrollo de la consciencia, un despertar delo individual, para comprender el colectivo del que se hace parte.

Lo precedente puede también sustentarse en los planteamientos de May (1974): "podemos [...] vivir ateniéndonos a nuestra propia integridad; o en un rapto de solidaridad, podemos identificarnos con el grupo [...] cada uno de estos caminos nos llevará al error si descuidamos el otro". Lo anterior permite vislumbrar la complejidad de vivir, que implica comprender, aceptar y coexistir con la antinomia propia dela viday, con ello, ser capaz de apreciarla y responder de las formas más idóneas frente a la innegable contradicción de la misma. Reconocer la antinomia, como bien lo esboza J ung (1952), es plantear la contradicción de la divinidad y concebirla como integralidad, como un todo, que permite considerar al ser humano como un complejo acontecer que permea 
entre lo bueno y lo malo, si se quieren usar categorías socialmente reconocidas y aceptadas. Entonces presupone la moralidad, un desarrollo de una consciencia viva y autorreflexiva ante el actuar del hombre.

Pero, ¿cómo sustentar la consciencia del hombre en procesos de autorreflexión frente a su actuar? Jung (1952) plantea que "el hombre debe ser afectado para que la acción de la pasión llegue a él. Debe aprender qué es lo que leafecta, pues tanto la ceguera del acto de violencia como la de la pasión se trasformarán así en conocimiento". Solo si el hombre tiene un despertar de consciencia y la asume con firmeza, y realiza su actividad con pasión, puede dar cabida al conocimiento verdadero, al conocimiento de vida, que es mayor al de la escuela doctrinante. El conocimiento de vida dinamiza su existir y lo moviliza para dar de sí lo mejor cada día, a fin de humanizar su actuar. Por supuesto, esto implica un actuar libre y responsable de su devenir formador como ser humano. A partir de allí, puede entender su existencia como actor participativo de los procesos transformadores de la sociedad en que vive.

En esta misma línea, May (1974) plantea que "la comprensión de que la existencia es a la vez alegría y dolor es el requisito previo a la aceptación de la responsabilidad por el efecto de las intenciones de uno". Al considerar este planteamiento, se puede fortalecer una vez más la concepción de que, solo con la comprensión de la integralidad como Ser Persona, se podrá reconocer la integralidad del otro $\mathrm{y}$, con base en ello, sustentar la conformación y construcción de grupos sociales saludables.

En palabras de Sagan (1994), "la vida busca a la vida, sobre el mundo transcurre la vida de todos, [...] conviven la alegría y el sufrimiento, héroes y cobardes, creadores y destructores de civilización, [...] inventores y exploradores, profesores de ética, santos y pecadores". En este sentido, todos conforman comunidad y depende del propio reconocimiento, la consolidación de una mejor sociedad fundamentada en el actuar consciente frente a los demás.

La finalidad real de la vida puede, entonces, comprenderse como el establecimiento de proyectos de vida, como estilos consagrados en pro de un desarrollo óptimo, un desarrollo de vida más humano, más cálido. Pues, si se tiene consciencia del propio devenir, puede fundamentarse la consciencia frente al devenir del otro.

En virtud de ello, pueden establecerse formas de actuar que sean favorables para el ser humano, que tal vez puedan colegirse como raras o atípicas, por el ausentismo del hombre, por el sentir de primacía y beneficio individual, sin procurar por el aprovechamiento de sus habilidades y cualidades, que puede ser direccionado en proyectos de vida más humanos y con perspectiva de colectivo, del cual se es parte por el simple hecho de constituirse como Ser Persona social por naturaleza.

De lo anterior, se puede deducir que, como ser humano y sujeto social, el hombre se reviste no solo como agente moral, sino como actor vivaz con capacidades y potencialidades sobre las cuales se funda la diferencia entre el vivir insensato y el vivir concientizado ante el mundo circundante.

Para hacer una transferencia y aprender los postulados anteriores, es pertinente considerar la siguiente premisa: "Pienso en la ética - como amor propio, amor a los demás y a lo demás, como cuidado de sí mismo, del otro y de lo otro, como auténtico estilo de vida- tal vez sea el último y único camino a seguir" (Sánchez, 1999). 
Lo anterior permite reflexionar sobre el sentido utópico de la vida. Fajardo y García (2011) proponen el concepto de utopía como la búsqueda de la justicia social fundamentada en el reconocimiento de los derechos y la necesidad de dignificar el ser. Si bien los autores hablan desde la perspectiva del derecho, la conceptualización de la cual la revisten se puede concebir como la construcción de un camino que conduce y construye la lucha por una sociedad con significado. Por ende, más digna y, en una palabra, más humana.

Lo mencionado anteriormente resulta cognoscible a la luz de los planteamientos de Viktor Frankl (s. f.) cuando refiere: "en una u otra forma, el hecho de ser hombre apunta siempre más allá de uno mismo, y esta trascendencia constituye la esencia de la existencia humana" (Velásquez, 2008). Es, entonces, objeto de la existencia, proporcionar significado y dotar de sentido la vida misma, y así salir de sí, para darse a los demás y desde allí poder aceptarlos con sus diferencias, colocarse sus zapatos y entender su realidad. Esto, presumiblemente, proporciona cabida a consideraciones más amplias. Por ejemplo, pensar en modos diferentes de enseñar y de aprender al interior de los procesos formativos del ser humano. Por otro lado, implica romper con prototipos de vida impuestos y aceptados que buscan responder a estándares sociales de consumo y automatizados.

\section{Conclusión}

Considerar el sentido utópico de la construcción de una sociedad más humana implica la transformación del sentir ausente de las personas hacia un sentir consciente y en procura del acontecer no solo propio, sino del otro, lo cual, se sustenta en el autorreconocimiento, favoreciendo así el reconocimiento del otro, el respeto por la diferencia y por todo lo que suscita vivir.

La intención es comprender y disfrutar la experiencia de vivir, por cuanto el ser humano es más que simples recetarios aprendidos. La experiencia del acontecer involucra, como ya se ha mencionado, un conocimiento consciente de la realidad propia del Ser, con el fin de fundamentar el actuar vital, decidido y responsable frente al acontecer del otro. Entendiendo que, antes de formarse como ser profesional, el constituirse como Ser Persona integral e íntegra es base fundante del desarrollo claro y decisivo para emprender cualquier actividad del vivir, pues reconocer la esencia del Ser y la forma de relacionarse con el mundo permite impregnar de significado el transcurrir de la vida. 
De Castro, A. (2000). La psicología existencial de Rollo May. Barranquilla, Colombia: Ediciones Uninorte.

Fajardo, L., \& García, L. (2011). Utopía y jurisprudencia constitucional. Bogotá D. C., Colombia: Universidad Santo Tomás.

J ung, C. (1952). Respuesta a J ob. México D. F., México: Fondo de Cultura Económica. Segunda edición 2006.

May, R. (1974). Las Fuentes de la violencia. Buenos Aires, Argentina: Emecé.

Sagan, C. (1994). Un punto azul pálido, una visión del futuro humano en el espacio. Madrid, España: Editorial Planeta. Cuarta edición 2003.
Sánchez-Corral, E. (2012). Orientación psicológica y justicia social. Temas selectos en orientación psicológica. Ética profesional del orientador psicológico. Vol. 6. México D. F. México: Manual Moderno.

Sánchez, T. (1999). El autoconocimiento como punto de partida. Exergía, revista de la Facultad de Ingeniería Mecánica. Universidad Santo Tomás, Bogotá, pp. 23-36.

Savater, F. (1999). Las preguntas de la vida. Barcelona, España: Ariel.

Velásquez, L. (2008). El sentido trascendente de la virtud humana. Poiésis, 15(2), 1-6. Recuperado de: http:// www.funlam.edu.co/ revistas/index.php/ poiesis/ article/ view/ 292/ 281

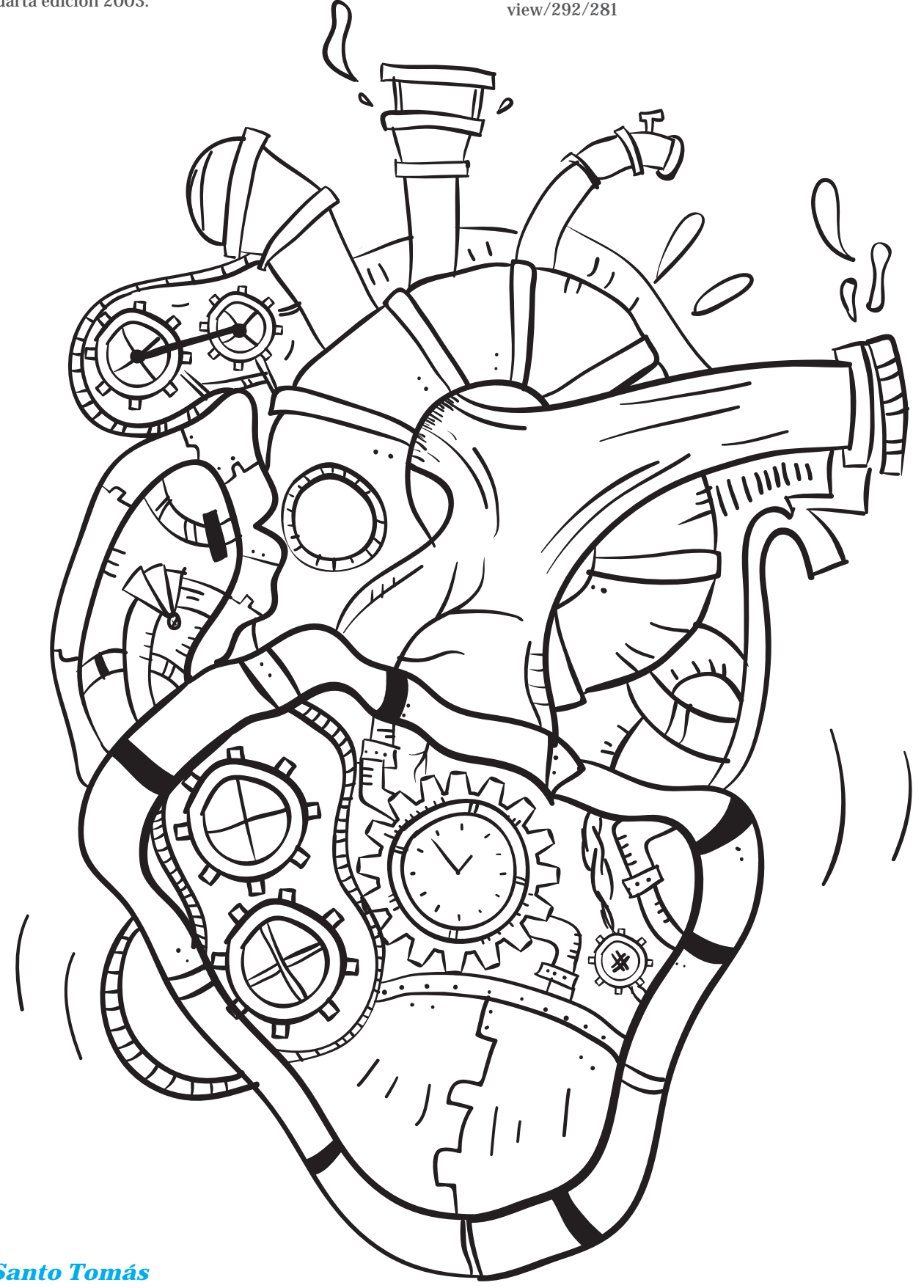




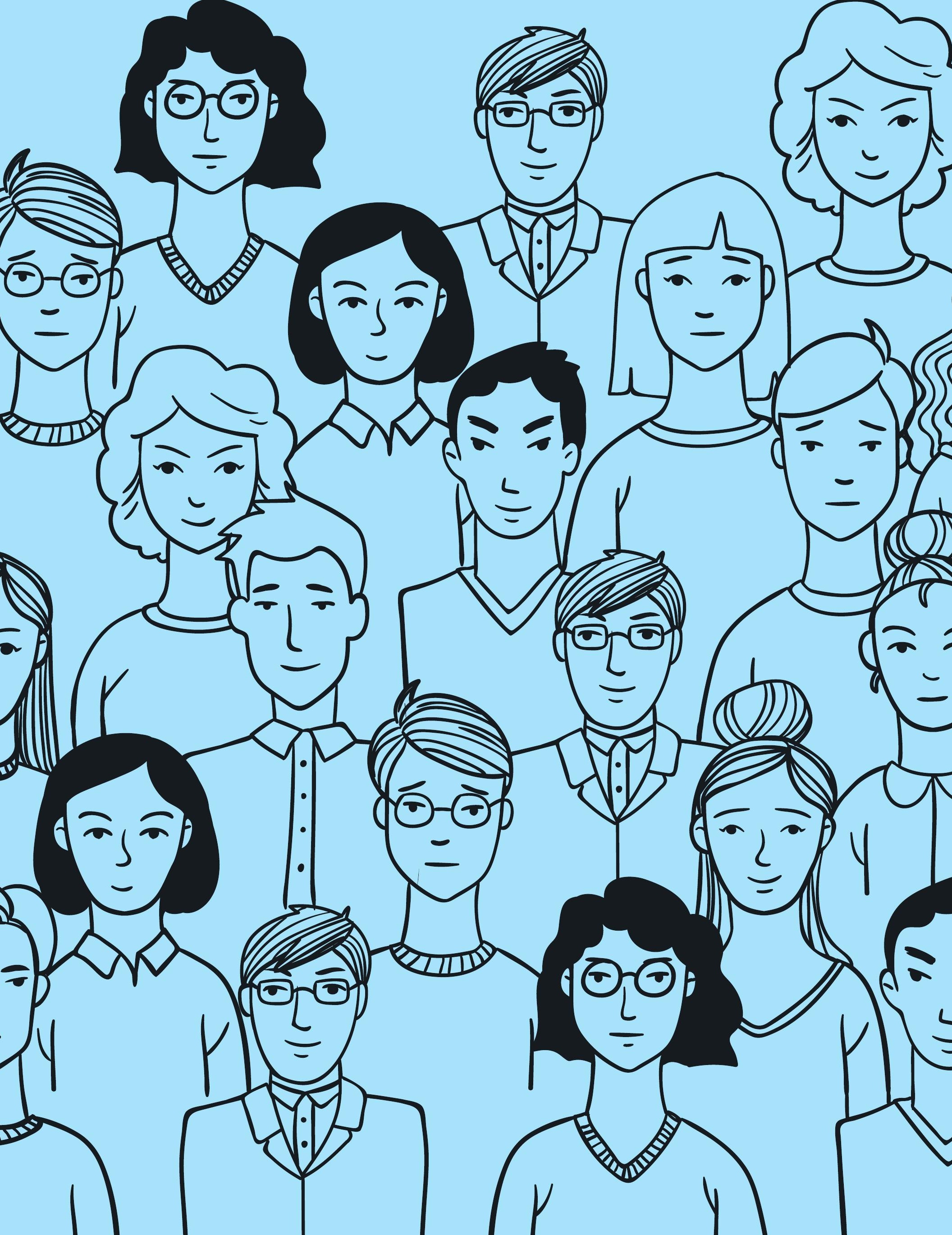




\section{Por una}

perspectiva

\section{planeación para el desarrollo}

François-Xavier Tinel $^{1}$
1Docente-investigador de la Maestría en Planeación para el Desarrollo y líder del grupo de investigación Conflictos sociales, género y territorios, Facultad de Sociología, Universidad Santo Tomás.

Correo electrónico: francoistinel@usantotomas.edu.co
- a idea de desarrollo está en boca de todos: ¿quién no habla de desarrollo? A su vez, está tan anclado en nuestros imaginarios que casi nadie se pregunta "¿qué es el desarrollo? ¿Por qué el 'desarrollo'? ¿De dónde viene y adónde va?” (Castoriadis, 1991). En efecto, el desarrollo sigue siendo una palabra gelatinosa que alude tanto al crecimiento de un niño, como a la maduración intelectual de una persona, al proceso de industrialización, al proceso civilizatorio, a la idea de bienestar o, incluso, al aumento de la riqueza nacional. En fin, es una "palabra fetiche" (Rist, 2002, p. 22) que, tomada de manera aislada, aparece como vacía de contenido en la medida en que logra cubrir toda la historia de la humanidad. Pese a que parece ser un término inmutable, que siempre hubiera existido, al estar tan presente en la cotidianidad de nuestro lenguaje y nuestras formas de comprender el mundo articuladas alrededor de un pensamiento binario como derecha/ izquierda, norte/ sur, desarrollo/subdesarrollo, entre otras, vale la pena señalar que el término desarrollo surge de manera tardía en nuestra modernidad occidental; es decir, solamente hace seis décadas. No obstante, esta nueva terminología para denominar procesos de cambio y mejora no será anecdótica, ya que va a constituir un nuevo lente para mirar la realidad social y como discurso llegará incluso a transformar las formas de autorrepresentación de las personas (Rist, 2002; Múnera, 2007; Escobar, 2006): ¿acaso no nos consideramos como "subdesarrollados" o "en vía de desarrollo" en comparación con "otros" ya "desarrollados"? Como lo señala Rist (2002):

Así, a partir de 1949, más de dos mil millones de habitantes del planeta van - las más de las veces sin saberlo- a cambiar de nombre, a ser considerados "oficialmente", podemos decir, tal como aparecen antela mirada 
del otro y a ser requeridos para buscar intrínsecamente la occidentalización con desprecio de sus propios valores: ya no serán africanos, latinoamericanos o asiáticos (por no decir bambaras, shonas, bereberes, quechuas, aimaras, balineses o mongoles), sino simplemente "subdesarrollados" ( $p .49)$.

Es así que el desarrollo fue entendido prístinamente como un proceso de mejora continua de los niveles de vida de carácter homogéneo y universal; retomando una analogía médica, se podría decir que poco importaba la "enfermedad" de la cual se padecía, ya que se aplicaba el mismo remedio: el crecimiento económico (Stiglitz, 2002; Reinert, 2007). Aún hoy en día, suele plasmar las expectativas de un futuro mejor asociado a una transformación económica, tal como lo había planteado Perroux (1955), mediante la correlación establecida entre desarrollo y crecimiento económico. En este sentido, varías fueron las metáforas del discurso desarrollista que pusieron de relieve la necesidad de movilizar una serie de fuerzas para superar un estado inicial de estancamiento económico o aun lo que se reconoce como la cristalización de una situación peligrosa, denominada "subdesarrollo", como las de big push (gran empuje) de Rosenstein-Rodan, el take off (despegue) de Rostow o el spurt (gran impulso) de Gerschenkron (Assidon, 2002).

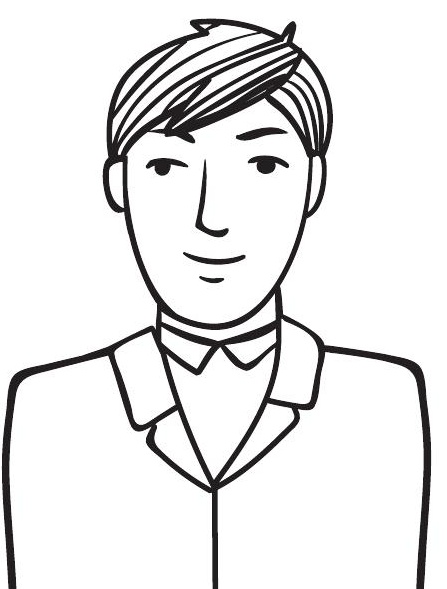

\section{El desarrollismo en tela de} juicio: aportes críticos de las ciencias sociales y de la doctrina social de la Iglesia

Empero, desde los años sesenta y setenta del siglo pasado, el balance contrastado de las experiencias del desarrollismo en los países del sur, así como el reduccionismo conceptual de la idea de desarrollo a su sola vertiente económica, hicieron que se erigieran, cada vez más, voces críticas. Entre ellas, resaltamos el grupo de expertos que se reunió en la Conferencia de Cocoyoc en México, en 1974, para establecer una nueva agenda del desarrollo alternativo y en la que plantearon que el objeto del desarrollo es el hombre, no las cosas. Asimismo, se realizó una distinción fundamental entre las prioridades relacionadas con los "límites internos" y los "límites externos". Los primeros se refieren a las necesidades fundamentales de la persona, como el alimento, el alojamiento, la salud y los derechos humanos, mientras que los segundos aluden a la integridad física del planeta y de sus habitantes. Paulatinamente, se estaba abriendo un camino para resignificar el desarrollo, desentrañar su dimensión humana y ética, lejos de los procesos de acumulación desenfrenada que promueve la economía capitalista; es así que de las alternativas de desarrollo o desarrollos alternativos que empezaron a proliferar a partir de esta época, como el desarrollo local (Boisier, 1999), el etnodesarrollo (Bonfil Batalla, 1982), el desarrollo sustentable y luego el desarrollo sostenible ${ }^{2}$, el desarrollo a escala humana

2 Para Fernández y Gutiérrez (2013), a diferencia del primero que se limita a preservar y gestionar recursos naturales, el segundo invita a una convivencia más armónica con la naturaleza y a una nueva ética cívica (2013). Otros, como Leff (2003) o incluso Escobar (2010), reconocen que estos términos ocultan la verdadera crisis ambiental y civilizatoria, inherente al modelo de desarrollo capitalista. El hecho de que los Objetivos del Milenio de las Naciones Unidas que se cierran en el año 
(Max Neef, 1993) y el desarrollo humano (Sen 2000; Nussbaum, 2000), se transitó hacía las alternativas al desarrollo, perspectivas más pesimistas o más realistas que anunciaban la "muerte" del desarrollo" (Sachs, 1996) ${ }^{3}$ y abogaban por el abandono del concepto (Escobar, 2003; Latouche, 2003).

No obstante, es importante recordar que ya, desde los años cuarenta del siglo pasado, el padre J oseph Louis Lebret planteaba, a través de la asociación economía y humanismo como horizontes de la economía, la búsqueda del Bien Común, el respeto de la naturaleza y de la dignidad humana. Es en su encuentro con la realidad latinoamericana del "subdesarrollo" que Lebret llegará a identificar el desarrollo como el problema del siglo, no solo como la búsqueda del crecimiento económico, sino también como la elevación humana de los pueblos. El descubrimiento de la dimensión humana del desarrollo está asociado también a una lectura distinta de las categorías analíticas de pobreza y riqueza, ya no alrededor del incremento del producto nacional, sino del valor de lo humano y de la humanidad en su conjunto. En este sentido, como lo expresa Lebret (1955), "si la economía humana tiene por objetivo y para hablar formalmente por 'objeto', la elevación humana universal, la primera tarea que se debe asignar a las actividades económicas es la de acabar con los niveles de vida inhumanos".

$\overline{2015 \text { den paso a los Objetivos del Desarrollo Sostenible, marca }}$ nuestra incapacidad para abandonar el término de desarrollo, y más aún, la imperante necesidad de validar la sostenibilidad de un modelo que ya se sabe insostenible.

3 Sachs (1996, p. 2) expresaba: "Los últimos cuarenta años pueden ser denominados la era del desarrollo. Esta época está llegando a su fin. Ha llegado el momento de escribir su obituario (...). Hoy el faro muestra grietas y ha comenzado a desmoronarse. La idea de desarrollo se levanta como una ruina en el paisaje intelectual. El engaño y la desilusión, los fracasos y los crímenes han sido compañeros permanentes del desarrollo y cuentan una misma historia: no funcionó”.
Así, el pensamiento lebretiano será una base fundamental para el desarrollo de la doctrina social de la Iglesia. En efecto, las conferencias episcopales de Medellín (1968) y Puebla (1979), así como las encíclicas Gaudium et spes (1965) y Populorum Progressio (1967), marcan un quiebre fundamental con un catolicismo autocentrado para sacar a la luz el compromiso histórico de la Iglesia con el pueblo de Dios. En suma, representan la invitación a una participación más activa de la Iglesia en el desarrollo de los pueblos y en la condena de las injusticias sociales. Por ejemplo, recogiendo el pensamiento de Lebret, entre otros, la Iglesia católica, en la carta encíclica Populorum Progressio entiende el desarrollo como un proceso intrínsecamente humano, y afirma que:

\section{El desarrollo no se reduce al simple creci- miento económico. Para ser auténtico debe ser integral, es decir, promover a todos los hombres y a todo el hombre. Con gran exac- titud ha subrayado un eminente experto: "Nosotros no aceptamos la separación de la economía de lo humano, el desarrollo de las civilizaciones en que está inscrito. Lo que cuenta para nosotros es el hombre, cada hombre, cada agrupación de hombres, hasta la humanidad entera" (carta encíclica Popu- lorum Progressio, 1967).}

Empero, si bien se logra recentrar la finalidad del desarrollo hacia el ser humano, no se alcanza a superar la mirada linealista del desarrollo, ya que se reconoce en la industrialización la mejor vía para alcanzar progreso humano y desarrollo. También, en Puebla (1979) se reafirma el compromiso social de la Iglesia alrededor de la "opción preferencial por los pobres" que constituyó el axioma principal de la conferencia 
episcopal de Puebla (1979). Esta preocupación por los más pobres y la preservación de la dignidad humana, pero con miras novedosas sobre la relación armónica que debe mantener el ser humano con el medio, se sustentó en la carta encíclica Sollicitudo rei socialis de J uan Pablo II en 1987:

"Para alcanzar el verdadero desarrollo, es necesario no perder de vista (...) la naturaleza específica del hombre", que es al mismo tiempo corporal y espiritual. "El hombre debe someterse a la voluntad de Dios, que le pone límites en el uso y dominio de las cosas, a la par que le promete la inmortalidad". (...) Según esta enseñanza, el desarrollo no puede consistir solamente en el uso, dominio y posesión indiscriminada de las cosas creadas y de los productos de la industria humana, sino más bien en subordinar la posesión, el dominio y el uso a la semejanza divina del hombre y a su vocación a la inmortalidad.

Dicho legado se ve reflejado hoy en día en la encíclica Laudato si que nos invita no solo al cuidado de la casa, sino nos recuerda nuestro compromiso con el otro: pobre, mujer, indígena, el marginado y el oprimido, dada la naturaleza desigual y excluyente del capitalismo moderno. En concordancia con la carta encíclica del papa Francisco, podemos decir que:

La problemática del desarrollo, “con o sin adjetivos", nos conlleva a afirmar que la apuesta por la vida, por la preservación del planeta, a partir de un replanteamiento profundo de las relaciones que se han mantenido hasta ahora con la naturaleza, se convierte en el principal imperativo ético y político, entendiendo que está en riesgo la supervivencia ya no solo de unas pocas especies, sino de la vida humana (Tinel, 2014, citado en PEP, 2015, p. 11).

En este sentido, la academia no es neutra. Debe y tiene una función social central a través de la educación, la de denuncia y anuncio. Por ende, se trata de una educación concientizadora que asume un compromiso histórico y político con la gentey las realidades territoriales vividas.

\section{La educación: de la denuncia al anuncio}

En el programa de Maestría en Planeación para el Desarrollo reconocemos que es fundamental, como parte del proceso de formación de magísteres éticos y comprometidos con la generación de soluciones que involucren al territorio y sus actores, participar en el proceso de denuncia y anuncio. Denuncia en tanto la crítica es necesaria para de-construir los imaginarios desarrollistas, así como para erigirse como una voz más, entre otras, que condena las prácticas destructoras del desarrollo capitalista sobre la vida y la cultura. En efecto, como lo señala de Sousa Santos (2014):

Vivimos en un tiempo en el que las más insólitas injusticias sociales y el más injusto sufrimiento humano no parecen ya generar la indignación moral ni la voluntad política de combatirlos de manera efectiva y de crear una sociedad más justa y equitativa. En tales circunstancias parece evidente que no nos podemos permitir desperdiciar ninguna experiencia social genuina de indigna- 
ción que quiera fortalecer la organización y la determinación de todos los que no han abandonado la lucha por una sociedad más justa (p. 18).

Anuncia en la medida en que ya existen respuestas antisistémicas, concretas y factibles a la naturaleza "tóxica" del sistema, como los caracoles del decrecimiento, las comunidades étnicas que luchan por la defensa de su autonomía y de sus territorios ancestrales o aun muchos otros que, sin ninguna afiliación ideológica, han optado por renunciar a la promesa de felicidad de la sociedad mercantil y adoptado valores distintos, los de la solidaridad y la reciprocidad, como ejes estructurantes de su existencia.

En este sentido, el programa de Maestría en Planeación para el Desarrollo busca redefinir lo que se entiende por planeación para el desarrollo, sobre la base de la afirmación del carácter polisémico de la idea de desarrollo, al ser una palabra pluriversal (depende de cómo se mira, quién la mira y de dónde se mira), y de la necesidad de otorgar otro sentido a esta aspiración humana de mejora, bien sea resignificándola o abandonándola, para posibilitar el reconocimiento y la existencia, tanto de otros modos devida distintos a los que ofrece la sociedad de la acumulación y del despilfarro, como de formaciones identitarias marginales y disidentes (Escobar, 2006). En efecto, la lectura tradicional se limita a comprender el ejercicio planificador como un proceso instrumental, como un mero proceso administrativo de gestión y aplicación de unas herramientas para la transformación territorial; en vez de ello, reconocemos en la planeación para el desarrollo un proceso problémico, sistémico, político e investigativo. Es por esta razón que se afirma que "la planeación para el desarrollo humano integral se sustenta en el reconocimiento de la dignidad de la persona, y también de su diver- sidad, y en una relación armoniosa con el entorno" (PEP, 2015, p. 12). Dicho de otro modo, tal como se plantea en el programa de maestría, la finalidad de la planeación no es la ejecución del plan en sí, ni siquiera el alcance de la meta: el desarrollo; estos no constituyen más que medios para la defensa, producción y reproducción de la vida humana y no humana. De alguna forma, como lo expresaba Lebret (1963), se busca elaborar una "ética del desarrollo" frente a la crisis civilizatoria que enfrentamos.

\section{Reflexiones finales}

Si bien por décadas los estudios del desarrollo constituyeron un "saber de dominio" resultado del saber "experto" de unos sobre otros que se expresaba en la realidad mediante las lógicas de la intervención, el replanteamiento del paradigma dominante nos convida a ver también en el desarrollo un "saber de comprensión", de ir al encuentro con el otro, descubrir su humanidad, y un "saber de emancipación" (Cortina, 2011): emancipación de la sociedad del crecimiento y de la acumulación sin límites, emancipación de las creencias antropocentristas ligadas a la experiencia desarrollista pasada y aún presente. A partir de ahí, el desarrollo, el "buen vivir", el vivir bien, el "sumak kawsay" para los quechuas, "swadeshi-sarvodaya" (mejora de las condiciones sociales de todos) según Gandhi, "bamtaare" (estar bien juntos) para los toucouleurs ( etnia fulani que vive principalmente en África Occidental ) o como quieran llamarlo, ya no es entendido como mecanismo para o un fin, sino como el espacio relacional con el otro y con la naturaleza que se sustenta en el diálogo de saberes, es decir, que reconoce la pluralidad y validez de los conocimientos heterogéneos. Lo que se plantea ahí es que, al descentralizar el saber (de la universidad a la pluriversidad), 
se puede también subvertir el poder y las formas de comprensión y construcción de categorías tan fijas y monolíticas como las de pobreza o de desarrollo.

Aunque es complejo y largo el compromiso asumido para la formación de unos planeadores éticos y críticos para el país, los trabajos de grado de los estudiantes del programa dan cuenta de un abandono casi completo de la lectura tradicional y racional del desarrollo reducida al mejoramiento de las condiciones materiales de vida y la experiencia del crecimiento económico para optar por otras perspectivas alternativas y más complejas, incluso más allá de la concepción del desarrollo humano integral, y comprender el desarrollo o la pobreza como un proceso problémico y en disputa, como lo reflejan los objetivos generales de investigación de estas estudiantes:

- Comprender la pobreza como una construcción socio-cultural a partir de las representaciones sociales de jóvenes de diferentes estratos socioeconómicos (Iraca).

- Analizar la relación entre el modelo de desarrollo local del municipio de Ricaurte (Nariño) en el marco de los planes de desarrollo 2008-2011 y 2012-2015 y "el buen vivir" de los planes de vida y de salvaguarda étnica del pueblo indígena awá (Natalia).

A su vez, tanto mediante el contenido microcurricular del plan de estudios como a través del proceso de investigación formativa se genera un reconoci- miento mayor de la gente presente en los territorios, de su diversidad y de sus saberes. En este sentido, quisiera citar a varios estudiantes:

- (...) queremos agradecer a los habitantes de la vereda Naguata, por su total disposición para darnos a conocer cómo el proceso de sustitución de cultivos tradicionales por cultivos de frutos cambió su calidad de vida y participó del desarrollo humano de la comunidad. Por contribuir a la academia por medio de sus experiencias laborales, sus conocimientos y sus expectativas de vida (Martha y César).

- En los pequeños municipios de Colombia, y en su gente, está el potencial de desarrollo humano y territorial de este país. Gracias por sus aportes y colaboración para la realización de esta investigación (Ana María y María Constanza).

En pocas palabras, compartimos con el filósofo noruego Henrik Syse que "hay otros valores, además de los que se negocian en la bolsa de valores" (citado en Bondevik, 2005, p. 23), los de la solidaridad, la reciprocidad, la gratuidad, la amistad, entre otros, que permiten una lectura distinta de esta palabra "mística", en tanto encarna una promesa salvífica, llamada “desarrollo". En este sentido, nuestra apuesta humanista en el programa de Maestría en Planeación para el Desarrollo no es tanto que los estudiantes adhieran a estos "otros" valores, sino que logren cuestionar los de la moderna sociedad capitalista para, a partir de ahí, participar de la búsqueda del Bien Común.

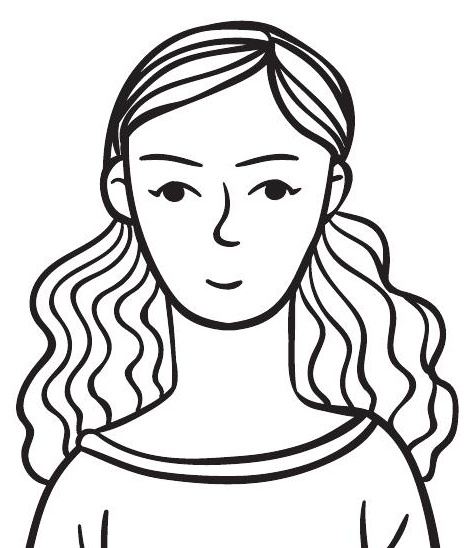

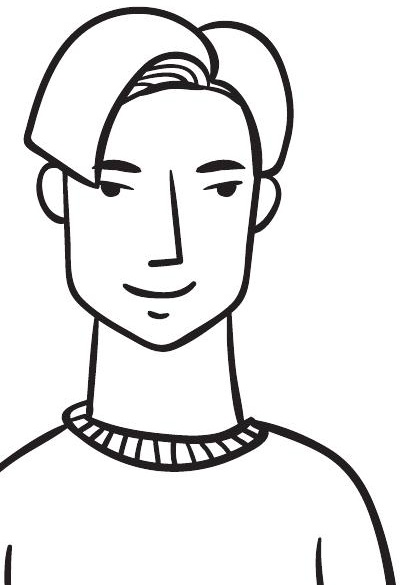

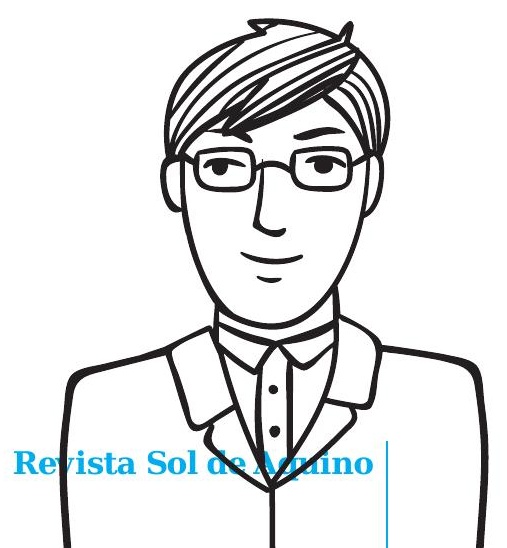




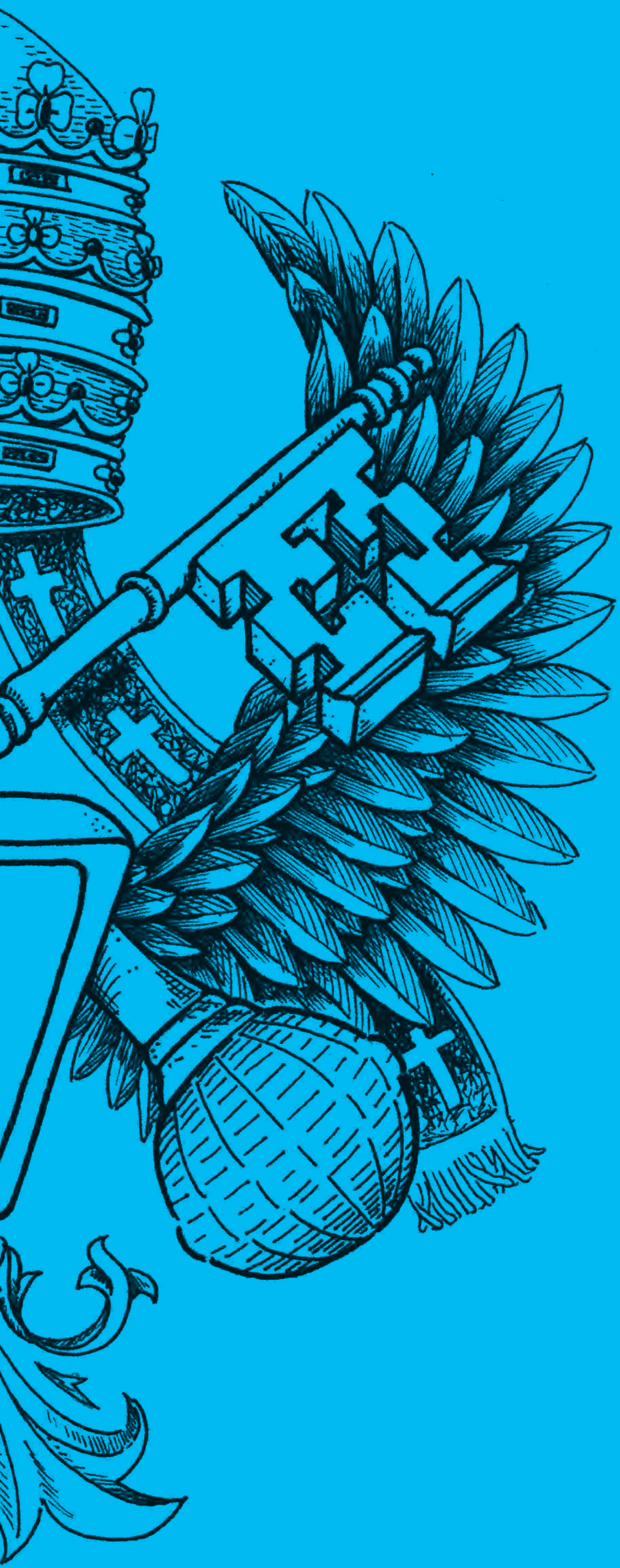

Misión

evangelizadora

de la

universidad

católica

Ernesto Fajardo Pascagaza ${ }^{1}$

1Docente del Departamento de Humanidades y Formación Integral (DHFI) de la USTA. Docente de Cultura Teológica.

Teléfono: 3106253489.

Correo electrónico: ernestofajardo@usantotomas.edu.co 
드 l concepto “evangelización” proviene etimológicamente de la palabra griega eu- angelion, que significa buena noticia, buena nueva. En este sentido, la tarea de la evangelización corresponde a la proclamación y al anuncio de una buena noticia, que desde el sentido cristiano es el anuncio de la Buena Nueva; es decir, de J esús, el Hijo de Dios y el Hombre, como el Salvador de la humanidad. La misión evangelizadora desde la primitiva comunidad cristiana ha sido proclamar el Evangelio, de tal manera que, al recibir el mensaje, genere un profundo sentido deadhesión en quien lo escucha. De esta manera, la presencia de J esús se vuelve cercana, toca los corazones delos hombresylos transforma al servicio del mismo Evangelio.

Se viven tiempos diferentes $\mathrm{y}$, por consiguiente, los métodos para dar a conocer el mensaje de salvación se deben adaptar a los signos de los tiempos, mostrando a un Dios cada vez más cercano a la cotidianidad, a la vida y a las necesidades de los hombres, sin perder la esencia original del mensaje cristiano, así como la orientación de la doctrina de la tradición eclesiástica.

J esús sale al encuentro del hombre y lo interpela con su presencia, llamándolo a vivir en la plenitud de los hijos de Dios para que comprenda el valor y sentido de ser persona digna y necesitada del amor misericordioso de Dios Padre.

El joven actual necesita de Dios, necesita de su presencia amorosa para que superelos relativismos de la sociedad globalizada en que vive y, por consiguiente, fundamente su quehacer existencial a partir de una sana doctrina. Es evidente que la sociedad contemporánea habla desde lenguajes ambiguos buscando adhesión a ateísmos pragmáticos, a la proclamación de la indiferencia, la incredulidad y el escepticismo religioso y, por ende, admitiendo como válidos aquellos argumentos que sean demostrables empírica- mente a partir del buen uso de la razón y que quita toda oportunidad a la contemplación del trascendente sentido dela vida y el proyecto del hombre desdelo religioso. En este sentido, lo que se puede esperar es una juventud sin esperanza, sin fe (Ratzinger, 1996), con profunda tristeza existencial, cansada de la vida, sobrecargada con lo efímero de la sociedad mercantilista y de consumo, llena de prejuicios, maltratada física y psicológicamente por su entorno familiar, laboral y estudiantil.

Desde el seno de la Iglesia hay una preocupación latente por el ateísmo, el cual es visto como un fenómeno grave en los tiempos actuales, fundamentado en varias raíces, entre las cuales está la incredulidad para comprender las diferentes pruebas dialécticas de la existencia. Esta expresión ciega de carácter metafísico se presenta, sobre todo, en contextos científicos, para quienes lo válido es el método positivo que da solamente viabilidad al conocimiento que se pueda probar experimentalmente o que corresponda a las leyes físico-químicas. Por otra parte, hay jóvenes que han logrado conciliar las expresiones científicas con la fe, integrándolas de manera armónica, permitiéndoles fundamentar su concepción frente al cosmos y su visión respecto al hombre. Pero, por otra parte, hay otros jóvenes que frente a estas miradas dialécticas, y sin poder lograr conciliarlas, han preferido alejarse tanto de los argumentos científicos como de los principios religiosos de fe, para dar lugar a pensamientos anticientíficos, a espiritualidades superficiales, a escepticismos, a expresiones de apatía o a pseudociencias o pseudorreligiones.

Ante estas diversas expresiones, la Iglesia convoca a una evangelización aplicando nuevos métodos, los cuales deben promover una fe sólida colmada de alegría para anunciar el Evangelio. Esta novedad implica compromisos contextualizados en ambientes distintos, con lenguajes diversos para hacer más 
próximo el mensaje salvífico. La realidad del Evangelio toca las culturas buscando dar respuestas a las necesidades de los hombres, expresando mensajes transformadores a partir de la presencia de J esús como el camino, la verdad y la vida, porque, en Cristo, la experiencia de Dios se vuelve verdadera y real (Ratzinger, 2001).

Proclamar el Evangelio implica ser claros y enfáticos, tener una sólida convicción de lo que se anuncia en espíritu y en verdad y dar testimonio desde la propia experiencia humana, para que, de esta manera, este mensaje anunciado despiertey motive en quienes lo escuchan la necesidad de adherirse, de establecer una relación íntima y personal con J esús.

Son innumerables las ideologías que han pretendido dar respuestas a las diversas necesidades del hombre en su devenir histórico, generando múltiples alternativas y paradigmas de solución, pero, por su parcialidad frente a la verdad, lo que han brindado es ambigüedad, confrontaciones y rivalidades en contra de la naturaleza humana y sus proyectos. Esto ha llevado a que se anuncie una nueva evangelización que transforme los corazones de los hombres, y que dé respuesta a sus inquietudes más profundas y sentidas. Por lo tanto, el anuncio de J esús es la razón de ser de la evangelización motivada por la fuerza iluminadora y santificadora del Espíritu Santo.

La Buena Nueva se comunica a través de la Palabra. Evangelizar es dar continuidad a la misión de J esús, es dar a conocer su mensaje salvador a partir de sus obras, de su palabra, de su vida y de sus enseñanzas. Por lo tanto, quien escucha atentamente y conoce a J esús le brinda una respuesta libre a su llamado y se compromete fielmente a seguirle para continuar anunciando, enseñando y predicando su Palabra a la humanidad.

Según lo anterior, el papel que cumple la universidad católica es fundamental para seguir dando continuidad a la obra misionera de J esús. Esta continuidad implica necesariamente conocer el misterio y la doctrina que respalda la obra misionera y, en este sentido, conocer las Sagradas Escrituras.

Son múltiples los desafíos y problemas que enfrenta la Universidad en el contexto actual y corre innumerables peligros al desvirtuar su fundamento en la búsqueda de la verdad y caer ante la inminencia de las crisis de identidad, fruto de los innovadores modelos de la globalización, de la tecnología, de los movimientos sociales, de la vertiginosa sociedad mercantilista, cosificadora y de consumo, así como de la irrupción abrumadora de las tecnologías de la información y la comunicación. Ante estas realidades, la universidad católica tiene grandes responsabilidades y compromisos, y el primero es tener a Dios presente en su proyecto institucional y considerar la religión como eje articulador de su misión educadora, porque forma parte de su catolicidad, de su confesionalidad en la formación de los futuros profesionales. 
La universidad es una comunidad académica que propende por la formación del pensamiento crítico, ético y creativo de sus educandos, y que contribuye al desarrollo integral de la dignidad de la persona humana y el rescate de la identidad cultural mediante las funciones sustantivas de la investigación, la proyección social y la docencia. Es un proyecto que no se agota en el contexto local, sino que se abre a horizontes más allá de las fronteras, buscando su cualificación y acreditación de alta calidad en su gestión administrativa y académica. La universidad conserva su autonomía institucional necesaria para cumplir su razón de ser respetando y garantizando la libertad académica enmarcada dentro de la salvaguarda de los derechos humanos y las exigencias de la verdad y el bien común (J uan Pablo II, 1990).

Ahora bien, la universidad, en cuanto a su expresión católica, debe necesariamente fidelidad al mensaje que se proclama desde el cristianismo (Juan Pablo II, 1990), y, por consiguiente, se inspira en las Sagradas Escrituras. La búsqueda de la verdad se inspira a la luz de la fe católica y el quehacer intelectual de la comunidad universitaria. Si la universidad católica se desvincula de su identidad e impronta católica que es su referente, simplemente se convertirá en una institución de educación superior como otra más y perderá su horizonte confesional.

Para el CELAM (2007), la universidad católica es de gran ayuda para la labor evangelizadora de la Iglesia, justamente porque es un escenario privilegiado para la construcción del conocimiento, para la investigación, para el desarrollo de la ciencia, para la reflexión y el debate. Si todos estos aspectos son trabajados desde la perspectiva de la formación religiosa, se tendrá una mirada de fe respecto a la valoración del hombre y su dignidad como persona. La universidad se vuelve evangelizadora cuando proclama el mensaje de Jesús sin temor ni temblor, con fidelidad a la Palabra (Poupard, 2011).

La universidad católica, al proclamar la Buena Nueva, se convierte en un escenario de encuentro en la búsqueda de Dios que toca las vidas de los universitarios y los invita a acercarse a Él. Una tarea de la universidad católica es la de contribuir en la formación y madurez en la fe de manera más sistemática y profunda de quienes deciden seguir a J esús en espíritu y verdad. De esta manera, este seguimiento libre y decidido ayudará a comprender que Dios es amor y es el fundamento de toda acción humana en la búsqueda de la justicia, la paz, la verdad, la fraternidad, el respeto, el perdón, el sentido de la vida y la felicidad.

La universidad católica tiene una misión de servicio a las nuevas generaciones para prepararlas a los nuevos retos que exige el mundo, inspirada en la fe cristiana católica, en la relación dialógica entre la fe y la ciencia, entre la fe y la razón. Así, la formación académica es de por sí una labor evangelizadora porque forma seres 
humanos dignos llamados a transformar el mundo desde su experiencia de fe. Cuando un joven se compromete lo hace con todo el empeño expresándolo en sus palabras y en su vida, pero no acepta la ambigüedad del doble mensaje; es decir, que una cosa sea la predicación y otra lo que se vive.

La universidad católica trasciende los escenarios de la academia para darle sentido a la cotidianidad del hombre en medio de sus anhelos de justicia y paz, y está llamada a renovarse continuamente para brindar respuestas a los grandes interrogantes del hombre actual y entre ellos están los jóvenes con sus intereses y motivaciones particulares.

La universidad católica enfrenta grandes desafíos y uno de ellos es la fidelidad a sus propios principios identitarios. La búsqueda de la verdad se orienta desde la Verdad de Dios, principio y fin de todo cuanto existe. En el contexto de la universidad católica se aprende, desde la formación integral, a construir la civilización del amor, a comprender los cambios culturales y las crisis sociales a la luz de la fe y la sana doctrina, se aprende a tener una aproximación humanística y de carácter espiritual al saber, porque la universidad católica es un modelo de familia, de casa de formación y de comunión entre todos los integrantes de esta comunidad. 
Referencias

CELAM. (2007). V Conferencia General del Episcopado Latinoame ricano y del Caribe. Documento de Aparecida. Recuperado de: http:// www.vicariadepastoral.org.mx/5- aparecida/ aparecida $12 . h t m \# 011$

Juan Pablo II. (1990). Constitución Apostólica Ex Corde Ecclesiae sobre las Universidades Católicas. Recuperado de: http:// www. vatican.va/holy father/john paul ii/apost constitutions/docume nts/hf_jp-ii_apc 15081990_ex-corde-ecclesiae_sp.html Consultado septiembre 2,2016

Paupard, P. (2011). Santo Tomás de Aquino y la misión de la universidad católica. Recuperado de: http:// www.uca.edu.ar/ .../SANTO TOM-S DE AQUINO Y LA VOCACI-N.doc

Ratzinger, J . (1996) Situación actual de la fe y la teología. Recuperado de: http:// www.mercaba.org/TEOLOGIA/Articulos/teo-003. htm Consultado agosto 20, 2016.

Ratzinger, J. (2001) La Nueva Evangelización según el cardenal Ratzinger. Recuperado de: http://www.campus.udayton.edu/ mary// resources/spanish/twelvet.html 


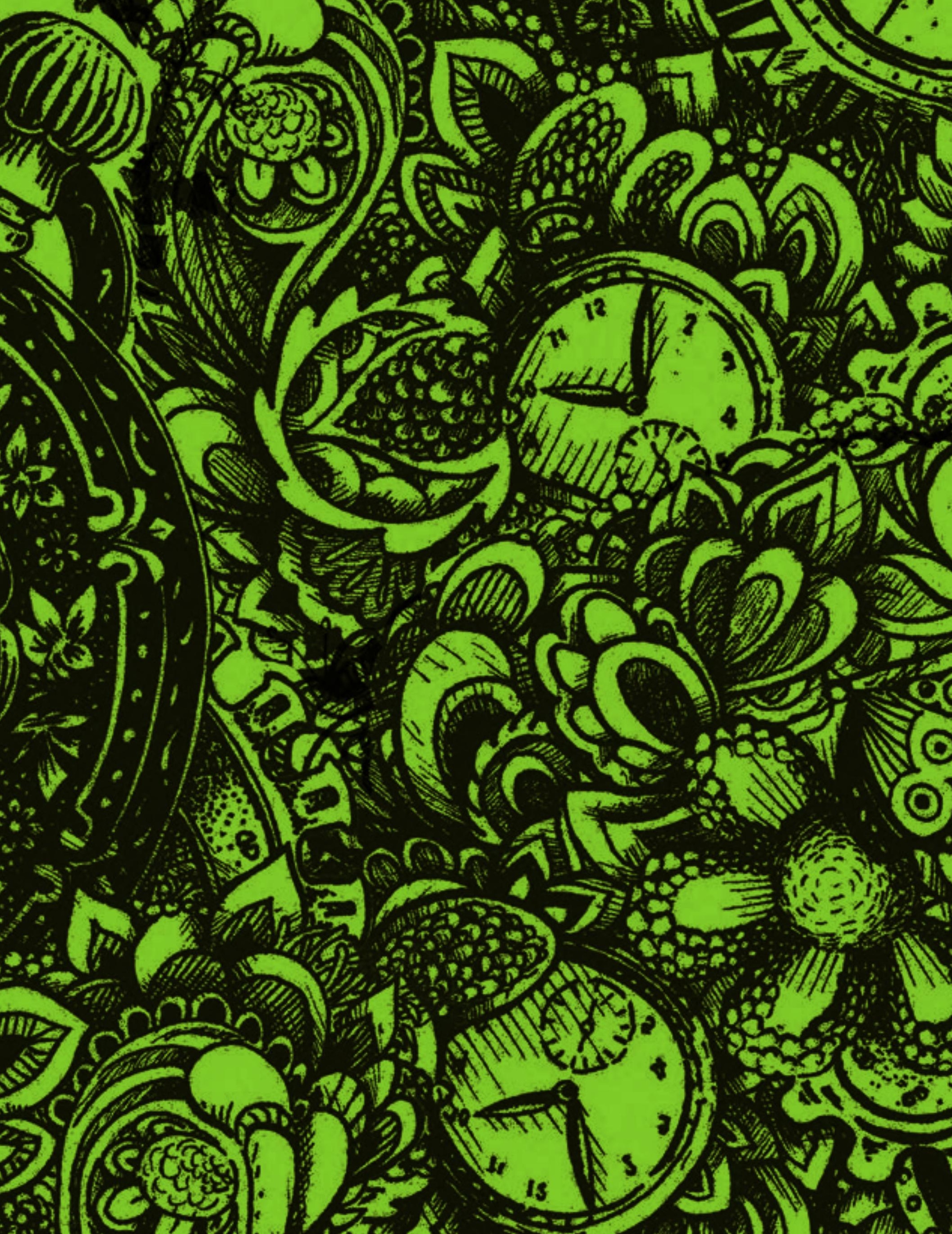




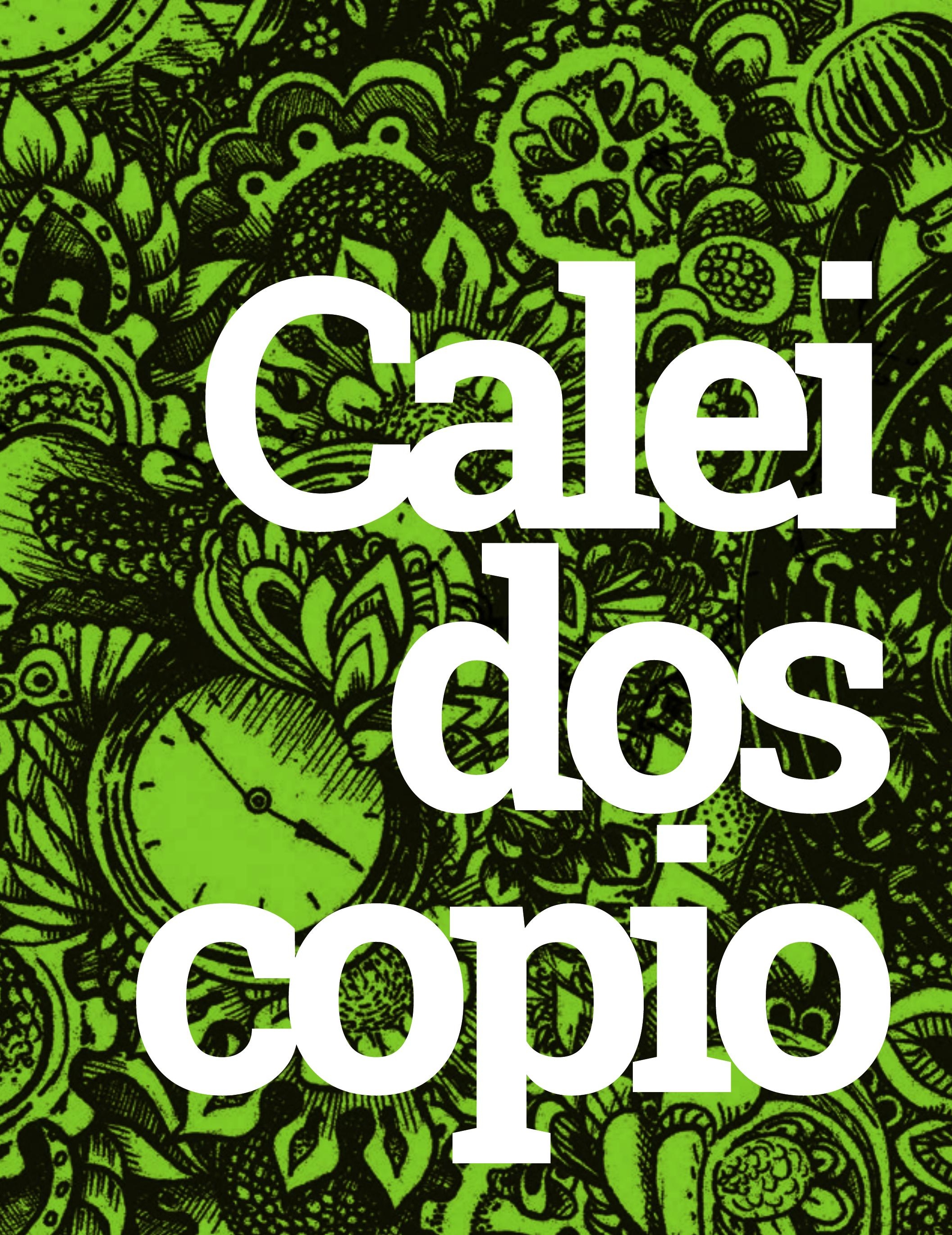




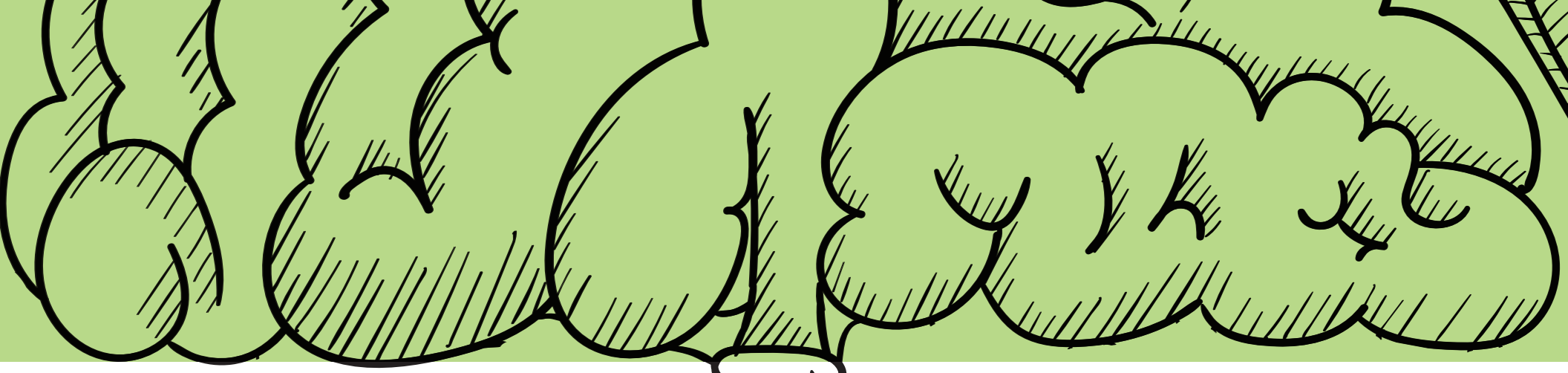

El axiologismo neoliberal y su incidencia en el capital social ${ }^{1}$ Daniel Garzón Quintero²

1 El "axiologismo neoliberal" se entiendo como la construcción y desarrollo de valores propuestos por la doctrina neoliberal, traducidos en cuatro ejes fundamentales: individualismo, competencia, eficacia y eficiencia, aunque su definición se va a ahondar a lo largo del documento. 2 Estudiante de economía, Facultad de Economía, Universidad Santo Tomás. Teléfonos: 350 725 6823/479 7388

Correos electrónicos: danielgarzonq@usantotomas.edu.co danielquintero2210@hotmail.com as sociedades contemporáneas han levantado el estandarte del capitalismo después de la caída del muro de Berlín. Este modo de producción se ha presentado como la única manera de lograr el crecimiento económico en las naciones, pero, desde comienzos de la Revolución Industrial y hasta hoy, ha incurrido en fallas históricas que han provocado la movilización de masas o la lucha por sistemas económicos alternos. Sin embargo, los ideólogos procapitalistas se las han ingeniado para salvarlo y sacarlo de sus innumerables crisis. En los últimos 30 años, para legitimar el poder económico y aumentar la participación de privados en sectores controlados por el Estado, los países de América Latina empezaron a tomar como guía el Consenso de Washington, un horizonte en términos de políticas económicas que tenía como fin la privatización. Por eso se comienzan a reestructurar tareas como las de aportes a la seguridad social y su recaudación, el recorte de gasto público en salud y educación, la creación de escuelas privadas, servicios de medicina pagada y a abrir los mercados para fomentar el libre comercio, entre otras. Un pequeño ejemplo en el caso de Colombia: "Se condujo al debilitamiento de la actividad productiva y financiera del Estado. Se liquidó el área de telecomunicaciones y se privatizó buena parte de las prestadoras de servicio público" (Kalmanovitz, 2010).

Es así como se implementa el modelo neoliberal con repercusiones económicas directas a largo plazo relacionadas con el desempleo, la salud, las pensiones, la vivienda, la pobreza, un aumento de capital foráneo, procesos de desindustrialización y un apogeo de la privatización, entre otras. Pero este modelo 

cambio político y económico también contempla de manera tangencial un cambio en los imaginarios dentro de las comunidades. En retrospectiva, este tipo de cambios se pueden ver con mucha facilidad, consultando un libro de historia universal. Los agentes individuales representaban diferentes papeles a lo largo de la línea temporal y el tejido social siempre ha sido diferente. La dificultad se presenta cuando se hace análisis de una coyuntura social, más desde un enfoque axiológico, y a eso hay que sumarle que lo contemporáneo presenta opiniones polarizadas entre los que acuñan los términos o intentan construir una definición ideológica. De manera reflexiva, la historia siempre nos presenta sus fallas y logros con el objetivo de no seguir o mejorar esos lineamientos, así que, antes de establecer las maneras sobre cómo se puede construir un capital social que beneficie el interés común, es menester definir de manera integral la coyuntura axiológica actual o por lo menos de los últimos 30 años.

Si el neoliberalismo es la forma moderna de liberalismo, que concede al Estado una intervención limitada en asuntos jurídicos y económicos, pero es el que se encarga de velar por los bienes y servicios público, estos dejarán de ser parte de lo común para darle prioridad a lo privado y se le dará paso a que otras entidades se encarguen de su administración, lo cual de inmediato transforma la manera como los individuos pueden llegar a interactuar con lo público y las relaciones sociales que pueden estar definidas más por el individualismo y el egoísmo. Para hacer una aproximación más acotada, Lechner define algunos parámetros sobre lo que imprime el neoliberalismo en la sociedad: "Vale decir, lo público ya no es primordialmente el espacio de la ciudadanía; en cambio, el mercado adquiere un carácter público y sus criterios (competitividad, productividad, eficien- cia) establecen la medida para las relaciones públicas" (Lechner, 1996).

El proceso de privatización transforma la sociedad en una "sociedad de mercado3; o sea, una sociedad con normas, actitudes y expectativas conformes al mercado" (Lechner, 1996), lo cual rompe con las tradiciones comunitarias establecidas en torno a lo público, que resultan desplazadas por los intereses individuales y, por lo tanto, debilitando el tejido social desde una perspectiva de creación cooperativa, puesto que el aumento de los intereses privados polariza la moral común y establece como norma general que cada individuo posea su propio sentido común.

De inmediato se identifica una de las barreras para la construcción de capital social dentro del esquema neoliberal, ya que las apropiaciones indebidas de un sentido común no pueden generar las condiciones para que las redes de tejido social produzcan escenarios donde predomine la confianza.

El individualismo y la competencia son dos componentes adjuntos que permiten que las capas sociales se separen más, las brechas socioeconómicas aumenten y la indiferencia sea algo común, debido a que estos dos componentes van en total contravía a la buena voluntad, a la fraternidad, al compañerismo y a la empatía, y a ese poder de sociabilidad que vincula a los seres humanos para lograr la colaboración y establecer bases para el bienestar común. Esto quiere decir que hay dos frentes axiológicos enfrentados entre el modelo neoliberal y el capital social. Por lo tanto, las sociedades pueden estar definidas de acuerdo con la prominencia de los unos y de los otros. Donde hay una preponderancia del neoliberalismo no puede existir un capital social constituido

3 Esta definición de sociedad de mercado está constituida sobre lo que pensaba Lechner acerca de las relaciones de gravitación social que adquieren los mecanismos de las sociedades capitalistas, donde "la mercantilización de las más diversas relaciones sociales moldea un nuevo tipo de sociabilidad” (Lechner, 1996). 
$\mathrm{y}$, al contrario, donde el tejido social esté fuertemente formado por unidad social y confianza, el NL4 no podrá filtrarse con facilidad.

Pero la eficiencia y la eficacia que también están bajo este lineamiento sí pueden tener otro comportamiento para la construcción de CS5. Por una parte, el NL le pide al individuo que minimice los recursos para obtener mejores resultados, o sea óptimo a la hora de tomar decisiones y producir resultados, pero si esto se aplicara en la construcción de tejido social tendrá un efecto multiplicativo positivo, siempre y cuando no se tenga en cuenta un modelo empresarial sobre la formación social. Para ser más exactos, Noam Chomsky nos ilustra con un ejemplo sobre qué pasa cuando estos métodos del NL se aplican en espacios de construcción intelectual y social, como son las universidades:

Contratos inestables, profesores temporales, flexibilización laboral, sobrecarga de trabajo, salarios injustos, escasa participación de la comunidad universitaria en la toma de decisiones, aumento de puestos administrativos y burocráticos, autoritarismo y exclusión, jóvenes sometidos a la presión delos créditosy las deudas, cursos superfluos, precios cada vez elevados, estudiantes que se limitan a tomar apuntes y a recitarlos de manera literal a la hora dela evaluación. Todo esto sucede cuando las universidades se convierten en empresas, como ha venido ocurriendo durante las últimas décadas, cuando el neoliberalismo ha ido tomando por asalto cada una de las dimensiones de la vida (Mendoza, 2014).
4 Neoliberalismo.

5 Capital social.
De nuevo encontramos un fundamento que desde esa perspectiva nos deja una sensación de malestar y pesimismo, sobre todo cuando se tiene una proyección positiva para la formación de CS, porque todos estos escenarios desorientan la identidad colectiva y multiplican las lógicas individuales, produciendo una sociedad diagnosticada con heterogeneidad estructural, una enfermedad social cancerosa, que lo único quenos deja son personas sin sentido común, con una diversidad radical, pero sin tolerancia. Y, además de todo, comunidades incívicas. Pero es muy temprano para hacer conclusiones, sobre todo con una proyección tan pesimista del CS. Es por eso que el CS recibe una alta dosis de intervención estatal para reforzarse y lograr ejecutarse, así que la formación de CS puede depender de qué tanto el Estado esté de acuerdo con las políticas del NL, pero el hecho de que empiece a formular políticas neoliberales no significa que deje a la deriva el destino del capital social.

\section{El tamaño del Estado y la estructura del capital social}

Anteriormente se han mostrado con detenimiento algunos ejemplos de lo que puede llegar a pasarle a una sociedad asociada con axiologismo $\mathrm{NL}$, pero hemos de detenernos y hacer énfasis sobre la moral definida por Kant, determinada como el conjunto de obligaciones que tiene un individuo para establecer un orden social donde primela libertad y el respeto. Kant era un fuerte exponente del estatismo puro y racional. Expresó a lo largo de las críticas de la razón, la tarea que tenía el Estado, el derecho, la moral, la política y el individuo para poder legitimar un orden social. Al Estado lo establece como un contrato social que debe coactar a los individuos para que se respete la libertad de uno y del otro. Sin embargo, la tarea moral que tiene cada indi- 
viduo es altísima, sobre todo cuando define el imperativo categórico que le brindan al individuo las herramientas integradoras suficientes para ser autónomo y disciplinado, logrando limitar su propia libertad para respetar la de otros.

Ahora, al involucrar las variables Estado, NL, CS y moral en una misma ecuación, podríamos encontrar puntos de equilibrio, siempre y cuando todas las partes involucradas se articulen de una manera asociativa para solo producir un mismo resultado: bienestar común.

Existen dos enfoques para la construcción de CS: desde una perspectiva comunitaria y desde otra institucional, que reflejan el papel de ambos actores en un escenario integrador, pero complejo:

Mientras los enfoques comunitarios y de redes, tienden a tratar el capital social como una variable independiente que da lugar a diversos resultados, la visión institucional lo vecomo una variable dependiente. El primer enfoque sostiene que la capacidad delos grupos sociales de movilizarse por intereses colectivos, depende precisamente de la calidad de las instituciones formales con las cuales funcionan (North 1990). La visión sinérgica, integra el desafiante trabajo proveniente de los ámbitos institucionales y de redes. Sin embargo, los Estados, empresas y comunidades, por sí solas, no poseen los recursos para promover un desarrollo sostenibley de amplio alcance; se requieren complementariedades y asociaciones entre diferentes sectores dentro de ellos. El papel del Estado en cuanto facilitador de resultados positivos de desarrollo, es el más importante y problemático (Saiz \&J iménez, 2008).
Así que la tarea más difícil es lograr que el Estado intervenga para que apoyeal CS, pero, ¿cómo se debe lograr esta intervención frente a unas barreras axiológicas del NL? ¿Será que aumentando el tamaño del Estado se pueda reforzar el tejido social?

Para llevar esta problemática a un caso pragmático, Salomón Kalmanovitz hace una revisión de las consecuencias de la Constitución de 1991 cuando retrata el resultado del cambio de Constitución que resulta en un escenario paradójico:

La disminución de las funciones económicas del Estado se complementó con un aumento sustancial de su tamaño... resultando un Estado mucho más grande, más burocratizado y con menos funciones que el que legó la Constitución de 1886, con una carga tributaria más pesada, que asigna mal los recursos públicos, de nuevo con tendencias centralistas y de concentración de poder (Kalmanovitz, 2010).

Así que el tamaño del Estado no siempre se traduce en resultados favorables para formación de CS. Resulta que aumentar la burocratización está muy relacionado con el clientelismo y, por lo tanto, con la corrupción, medidas que van en contra de una moral honorable, que respete las redes. Entonces provoca la desacreditación de la legitimidad estatal. ¿Por qué? Porque las comunidades ven que es más fácil crear pequeños gobiernos (o colectivos) mucho más eficientes de lo que presenta el Estado. Esto sin previa autorización estatal, pero tampoco va en contra del sistema político ejecutado. De lo contrario, la intervención estatal tendría un efecto negativo, porque vería amenazado su monopolio de poder. 


\section{Conclusiones}

La tarea que tiene el Estado para regular la axiología neolioberal es sumamente importante. Sin hablar de las consecuencias económicas que traen estas medidas, el CS podría encontrarse en crisis si no se logra articular una moral general para todos los individuos donde el Estado sí esté visible para todos, donde la fe depositada en el interés privado se transforme en interés común. Pero esto tal vez implicaría reformular la propuesta neoliberal con mayores restricciones hacia el modelo. Intentar llegar a un punto medio entre el tejido social y el NL es tarea de las comunidades y el Estado y su oportuna gestión de actividades donde se fomente la cooperación entre las partes. Esto quiere decir que se involucre a las personas en decisiones y políticas estatales con lineamientos planificados, donde el escenario no esté retratado por un Estado que está en función de la propuesta neoliberal.

Por lo tanto, la importancia del CS para fomentar el crecimiento positivo de la moral ciudadana a priori, pero sin valores orientados al desarrollo y bienestar comunitarios, no nos ofrecerá más que una sociedad polarizada y destinada a odiarse a sí misma por lo que es.

\footnotetext{
Referencias

Bourdieu, P. (1979). Los tres estados del capital cultural. Actes de la Recherce en Sciencies Sociales, 11-17.

Fernández-Steinko, A. F. (2009). Neoliberalismo: auge y miseria de una lámpara maravillosa. El Viejo Topo, (253), 6-15.

Fernández-Steinko, A. (2010). Cambio del modelo productivo. El Viejo Topo, (273), 44-51.

Kalmanovitz, S. (2010). Nueva Historia Económica de Colombia. Bogota D. C., Colombia: Tauros Historia.

Lechner, N. (1996). La política ya no es lo que fue. Nueva Sociedad, (144), 104-113.

Mendoza, M. L. (13 de marzo de 2014). El neoliberalismo tomó por asalto a las universidades: Noam Chomsky. El Espec-
} tador.

Banco de la República. (2011). El neoliberalismo. Recuperado de: http:// www.banrepcultural.org/ blaavirtual/ ayudadetareas/ poli/poli70.htm

Robledo, J. E., \& Vásquez, G. H. (2007). Filosofia y teorías políticas entre la crítica y la utopía. La globalizacion neoliberal niega la democracia (pp. 69-82). Buenos Aires, Argentina: CLACSO.

Rodas, F. C. (2014). Pasado y presente de la filosofía política. Medellín, Colombia: Editorial Universidad de Antioquia.

Saiz, J . E., \&J iménez, S. R. (2008). Capital social: una revision del concepto. Revista CIFE, 250-263.

Vadillo, M. A. (12013). Los valores neoliberales corrompen hasta en la escuela. Recuperado de: http://mvadillo. com/2013/10/ 10/los-valores-neoliberales-corrompen-hasta-en-la-escuela/ 


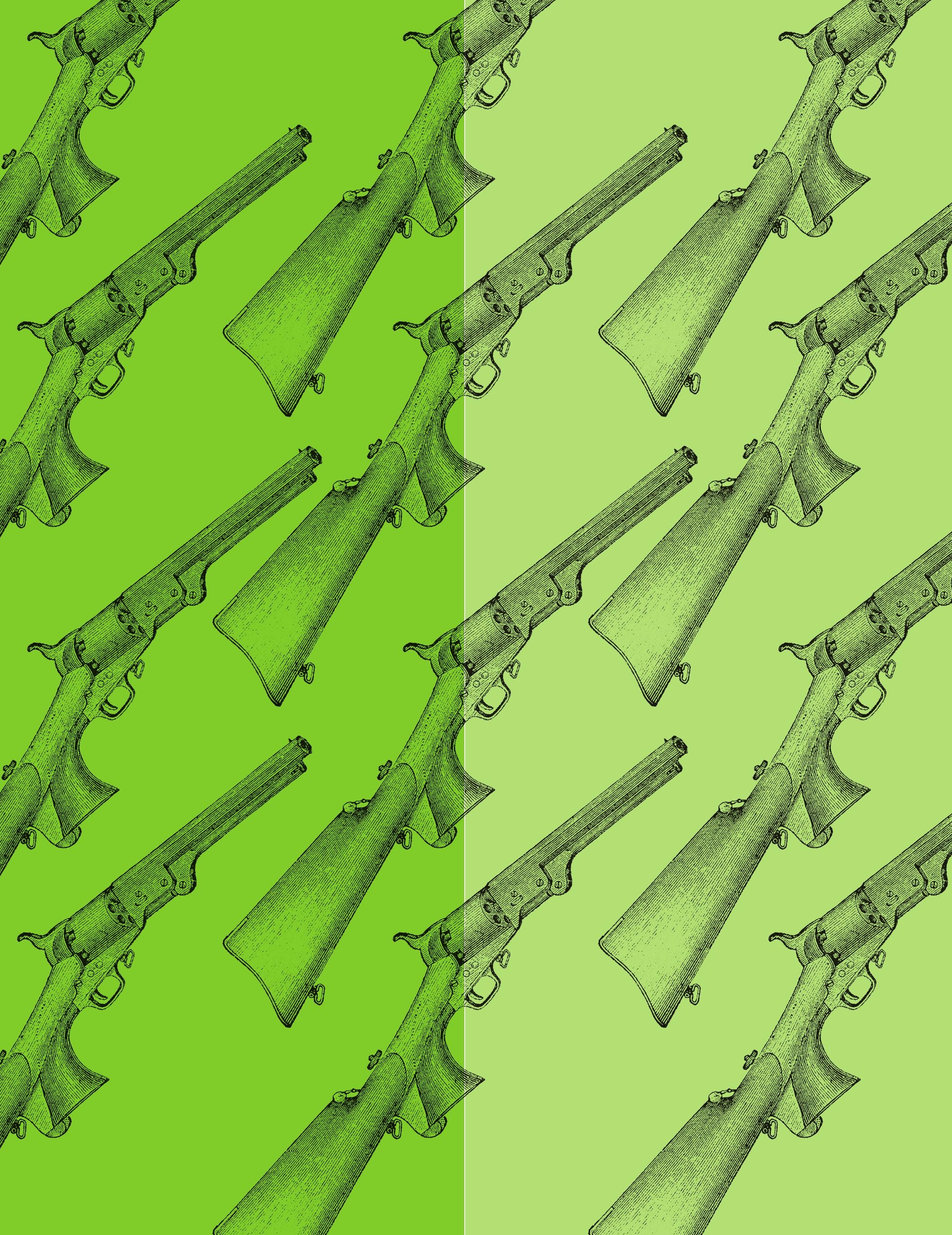




\section{Macroeconomia e inflación en la Guerra de los Mil Días: ¿un asunto litográfico? Brenda Lyced Carreño Ortiz ${ }^{1}$}

1 Estudiante de décimo semestre de la Facultad de Derecho de la Universidad Santo Tomás, sede Bogotá, y estudiante de primer semestre de la Especialización en Derecho Penal de la misma Universidad. Teléfono: 3188552229.

Correo electrónico: brendacarreno@usantotomas.edu.co
- l período decimonónico de Colombia estuvo atravesado por la contraposición política entre partidos y sectores sociales. Las revoluciones de independencia legitimaron la posibilidad de posicionar nuevos sujetos en el poder, diferentes a los de la Corona española. Pero ello no redundó en la estabilidad socioeconómica del territorio nacional.

La necesidad de configurar un Estado-nación se concebía desde proyectos disímiles en constante beligerancia. Las múltiples guerras civiles del siglo XIX son la más clara contradicción frente a aquellas bellas utopías que los próceres de la Independencia proclamaban a viva voz.

El siglo XIX, por lo tanto, se configuró como un período histórico encapsulado por los litigios políticos que, a su vez, dependían del deseo de muchos habitantes, o por hacer parte de las élites nacionales o por no quedarse sustraídos de la coyuntura histórica. Es en ese sentido como puede interpretarse la Guerra de los Mil Días: como un conjunto de acciones políticas y militares que afloran cuando se hace imposible la concordancia de líneas de pensamiento, ideologías o concepciones.

Dentro de las múltiples guerras civiles del siglo XIX, la Guerra de los Mil Días fue, sin duda alguna, la más devastadora, en tanto repercutió de manera extrema y crítica sobre los ámbitos sociales, económicos y políticos. Fueron muchos los factores que confluyeron para que esta guerra tuviera lugar, pero, “analizados históricamente, estaban expresados en la división de los partidos, las bajas de los precios del café y un sistema electoral que era fácilmente manipulado por el gobierno" (Ardila, 1983, p. 25) ${ }^{2}$.

No obstante, entre la amplitud y complejidad dela guerra, entre el abanico de posibilidades por analizar

2 Tesis de Licenciatura en Ciencias Sociales, Universidad de la Sabana. 
causas, desarrollos y consecuencias, queremos en el presente artículo hacer una aproximación socioeconómica al fenómeno de la hiperinflación que se generó por la excesiva producción y circulación de papel moneda. Al parecer, las visiones macroeconómicas del período en estudio hacían especial énfasis en las dinámicas litográficas: las preocupaciones monetarias tuvieron que ver más con asuntos técnicos que con los propiamente económicos.

\section{Las emisiones de papel}

\section{moneda a finales del siglo XIX y durante la guerra civill}

En primer lugar, es importante resaltar que en las últimas décadas del siglo XIX la figura de la banca central tenía solo un aspecto difuso. Sus funciones no eran claramente comprendidas ni definidas y en lo atinente a la emisión del papel moneda no asumía acciones efectivas de regulación. Henao nos plantea que en 1881 el Banco Nacional realizó una primera emisión de billetes con ayuda de la Litografía Paredes, pero, desde los años ulteriores hasta el final del siglo, el panorama litográfico era notablemente profuso: American Bank Note Company, Imprenta Chaix, The Home Lee Bank Note Co., Hamilton Bank Note Engraving \& Printing Co., Litografía Nacional, entre otros (Henao, 2000).

$\mathrm{Si}$ a lo anteriormente descrito se le suman los hechos de que el Banco Nacional aún no generaba una confianza aceptable, de que los bancos particulares y regionales tenían mayor reconocimiento y emitían además sus propios billetes y que aún no existía un sistema monetario unificado en el país, no podemos imaginar unos mecanismos de circulación monetaria más confusos y problemáticos que aquellos vividos en la época.
Para cuando se desata la Guerra de los Mil Días, el terreno económico era bastante inestable y heterogéneo. La estrategia gubernamental no se ubicó ni en el plano del préstamo ni tampoco en el lugar de la disposición de los recursos propios del Estado (que, a decir verdad, solo podrían pensarse en término de déficit). La maniobra económica se fijó en la producción litográfica de billetes ${ }^{3}$.

El diseño y la impresión de los billetes presentaban numerosas dificultades para la época: escasas litografías e imprentas, poco tiempo para amparar circulante seguro, poca aceptabilidad por parte de la población e incomprensión de las consecuencias inflacionarias de la emisión acelerada y descontrolada de dinero, entre otras.

Las primeras emisiones para la guerra llevaban fechas de 1899 y 1900. En ellas se veían variadas escenas alusivas a la época y empieza a cobrar relevancia la figura de los políticos conservadores más influyentes del momento. "Un examen, aún superficial, muestra papeles y tintas de mala calidad, combinaciones de tonos desagradables y el dibujo se nota con frecuencia apresurado y poco atractivo" (Henao, 2000). Se pone de manifiesto la falta de calidad y de tiempo en la producción del papel moneda.

La necesidad acuciosa de disponer de papel moneda hizo que hasta los impresores locales realizaran de emergencia, por encargo del Gobierno, billetes con cualquier tipo de letra, forma o imagen representativa (Ardila, 1983) ${ }^{4}$. Como consecuencia de la baja ca-

\footnotetext{
3 Nos resulta particularmente extraño el planteamiento de que la producción de dinero esté relacionada con un asunto de impresión, cuando en nuestros tiempos no es bastante claro que el obtener dinero solo es factible y lícito cuando se desarrolla una actividad económica. Frente a esto, la pregunta: ¿fue lícita la acción emprendida por el Gobierno conservador para subsidiar la guerra?

4 Ardila recrea que era tan imperiosa la necesidad de obtener liquidez y tan deficientes en sí mismos los recursos tecnológicos para su producción, que incluso se tuvo que recurrir al papel con el que se envolvían chocolates, por lo que durante tiempos de la guerra algunos billetes tenían impregnado tal olor.
} 
lidad en la producción de los billetes se favoreció la facilidad para falsificar gran cantidad de ellos.

Como se puede analizar, el circulante del país durante la guerra civil adoptaba proporciones exacerbadas (había más de mil millones de pesos en un país de cuatro millones de habitantes), lo que condujo a la inflación más alta en la historia de Colombia.

\section{El fenómeno de la inflación durante el transcurso de la guerra.}

Imaginémonos por un momento la situación de una persona de la clase alta, un hacendado, que haya experimentado el rigor de esta guerra civil. Antes de la guerra su trabajo se veía reflejado en la cantidad de dinero y de riqueza que lograba obtener. La relación entre el dinero y el trabajo guardaba cierto equilibrio.

Cuando comienza la guerra, el Gobierno produce de la nada el dinero para sostener las tropas, proveer las armas, satisfacer necesidades específicas. El exceso de dinero en circulación hace que los precios de los productos se incrementen y que, por lo tanto, haya una pérdida en la capacidad adquisitiva de la moneda.

Cuando el hacendado vaya a comprar un producto en los tiempos de la guerra, se dará cuenta de que su dinero se le está escapando de las manos, que se está empobreciendo, que incluso puede quedar en la ruina. El trabajo que realiza no se ve compensado con el valor de su dinero ni tampoco con las riquezas o productos que pueda obtener.

El hacendado presenció "un aumento sustancial, persistente y sostenido del nivel general de precios de una economía” (Banco de la República, 2006). En general, lo que vivieron las personas en este período histórico fue el fenómeno de la inflación en el que los precios de los bienes y servicios crecían en una tasa muy superior a las que se materializaban en un trabajo específico (por ejemplo, la agricultura o la artesanía). La causa de la inflación de la época fue el gran flujo de dinero circulante con evidente pérdida de su valor y con disminución significativa en su posibilidad de liquidez.

En el trasfondo de la mencionada medida litográfica, lo que sucedió fue que las personas estaban concediendo un tributo indirecto a la guerra bipartidista, lo que se veía reflejado en el hecho de necesitar demasiado dinero para adquirir bienes y servicios o, como seguramente ocurrió en muchos casos, en la imposibilidad misma de su consecución. La "producción desmesurada de billetes generaría una fuerte alza en los precios internos: la tasa de inflación llegó a un promedio de $100 \%$ anual, con un aumento crítico en 1901 cuando la tasa de inflación llegó a 389 \% anual” (Banco de la República, 2006).

Es verdad que las problemáticas inflacionarias tenían antecedentes desde antes de que estallara la guerra, pero "la verdadera inflación galopante se desencadenó con el vértigo tipográfico" (Caballero, 1970, p. 135). La escasez de recursos del Estado para subsidiar la guerra, en articulación con los altos costos de esta y la iniciativa de emisión de dinero, solo podía redundar en una consecuencia nacional negativa hacia la economía de los ciudadanos, pues eran ellos, en última instancia, los que estaban corriendo con los gastos de la guerra, incluso cuando pretendieran dejarla de soslayo.

En definitiva, la hiperinflación de 1901 fue originada por factores extrínsecos a la naturaleza de la economía: la guerra. La altísima tasa de inflación implicaría para cuando terminase la guerra la puesta en marcha de una serie de medidas financieras y estatales para estabilizar la economía. "Sin embargo, fue 
solo en 1923 con la creación del Banco de la República cuando finalmente se logró la estabilización de la moneda" (Henao, 2000), pues empezó a configurarse un sistema de homogenización y regulación monetaria en el país.

\section{Referencias}

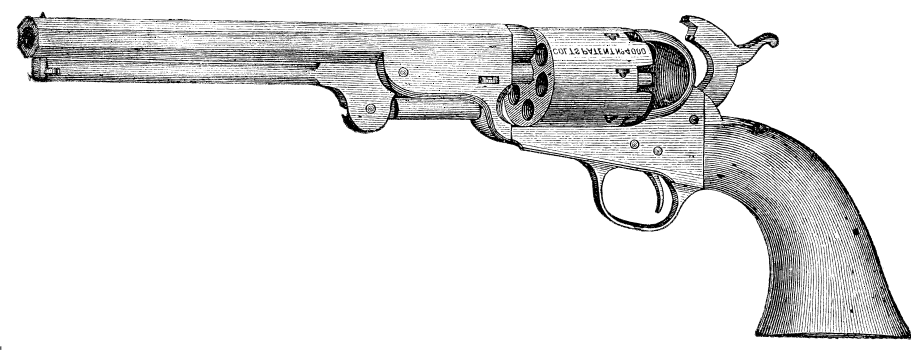

Ardila, M. (1983). Papel de la Guerra de los Mil Días en la dinámica social colombiana. Tesis de Licenciatura en Ciencias Sociales. Universidad de la Sabana, p. 25. Bogotá D. C., Colombia.

Banco de la República. (2006). El dinero y la política monetaria. Recuperado de: http://www.banrep.gov.co/documentos/publicaciones/material_educativo/guias_escolares/5_la_inflacion.pdf

Caballero, E. (1970). Historia económica de Colombia. Bogotá D. E., Colombia: Italgraf.

Henao, I. (2000). Cien años de los Mil Días. Billetes en tiempo de guerra. Revista Credencial Historia. Agosto. Recuperado de: http:// www.lablaa.org/ blaavirtual/ revistas/ credencial/ agosto2000/ 128lassenas.htm

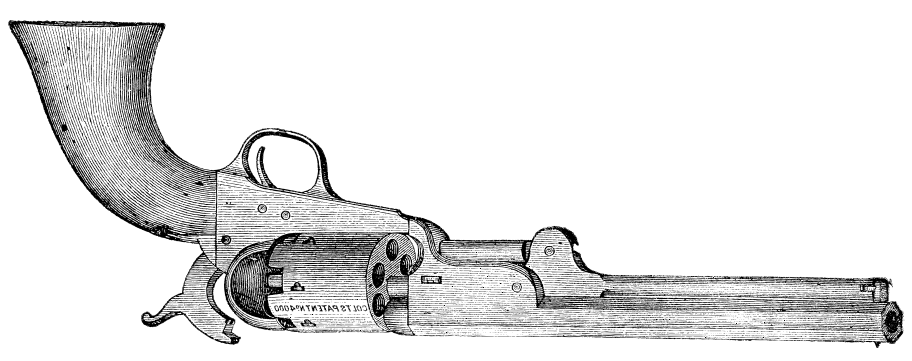




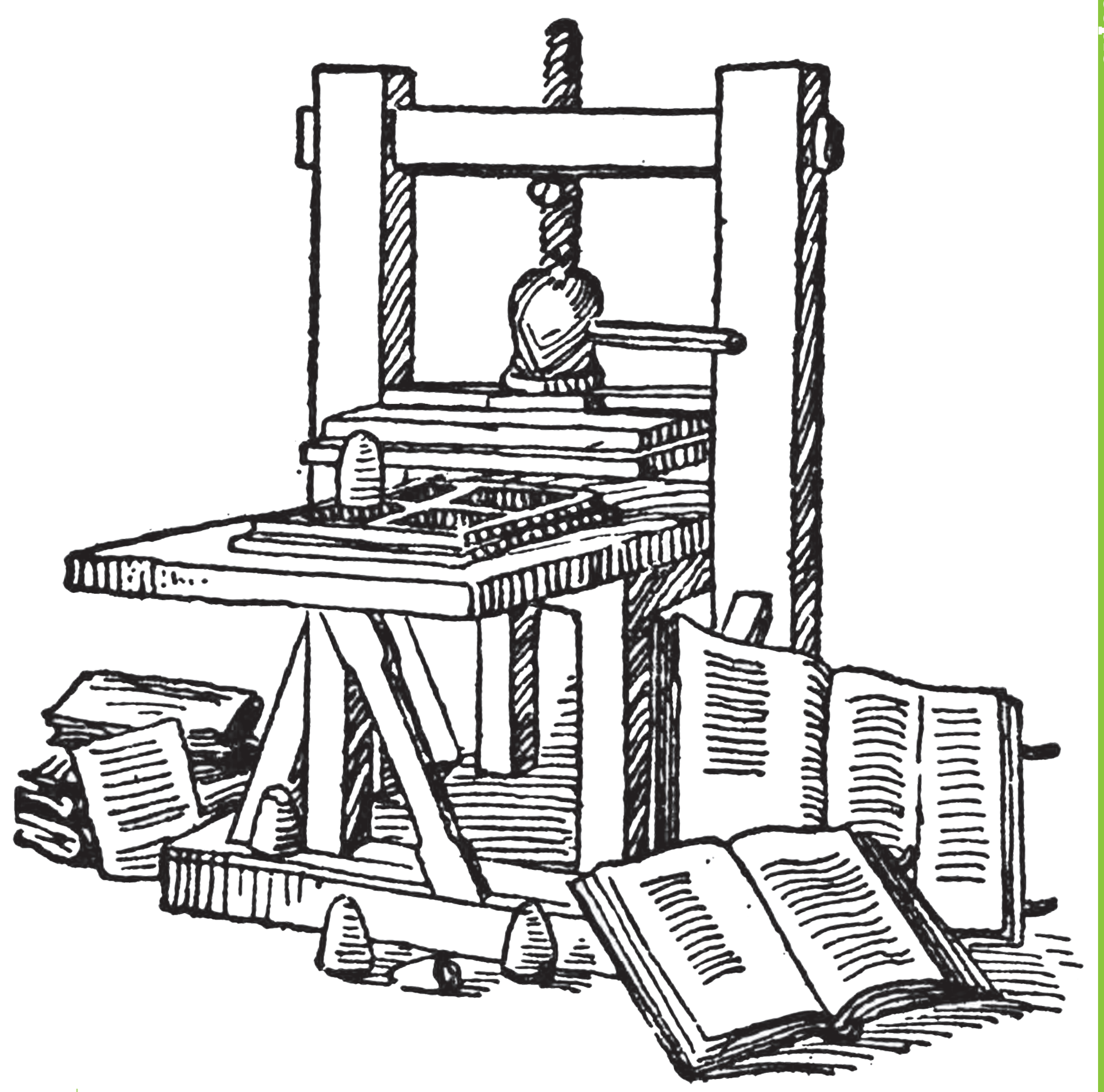




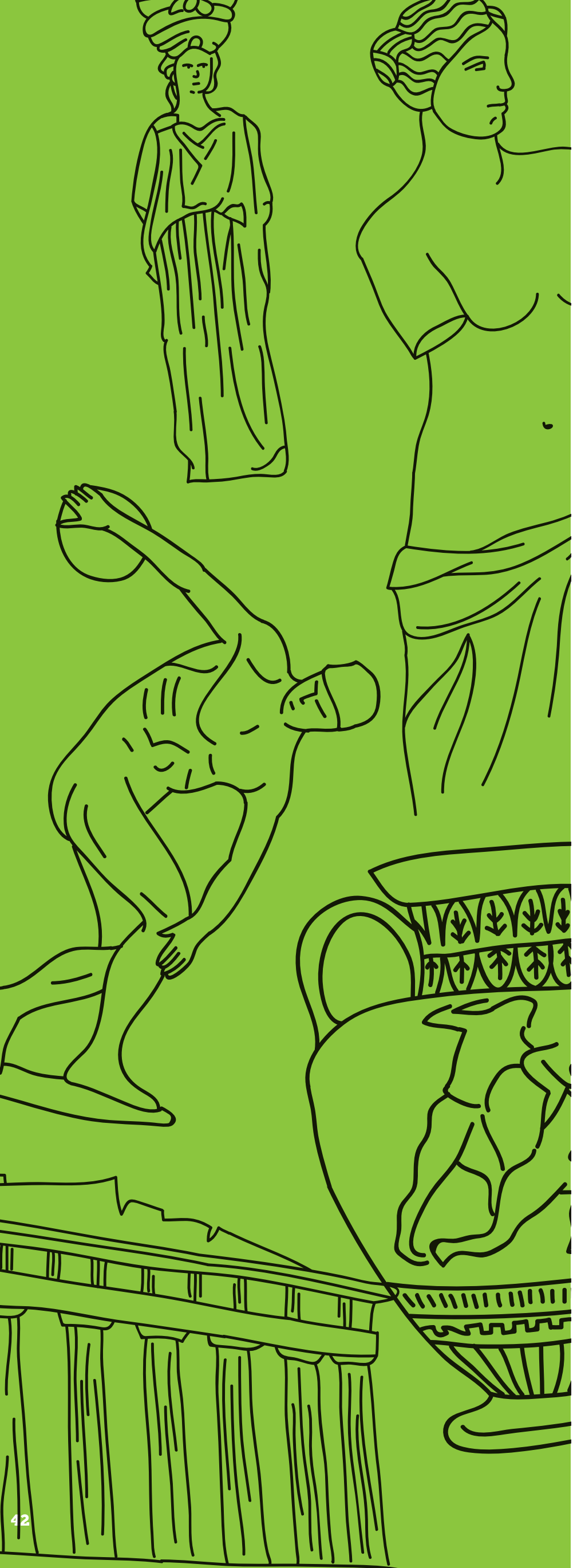

\section{La danza en la} tragedia griega clásica.

Laura Nataly Bello López

“Danzar es hacer un texto en el cuerpo a partir de metáforas corporales (...). La danza es considerada un evento que puede leerse, es un discurso codificado, en tanto que es consciente para quien lo vive y, comprendido para quien lo observa; en escencia, es la comprensión del cuerpo en movimiento". Rosana Barragán Olarte

1 Estudiante de cuarto semestre de la Licenciatura en Filosofía y Lengua Castellana, Facultad de Filosofía y Letras, Universidad Santo Tomás. Correo electrónico: laura.bello@usantotomas.edu.co 


\section{La danza en el rito dionisíaco}

\author{
“...El corazón de un hombre es como \\ un pájaro enjaulado. Cuando bai- \\ las, tu corazón canta y se eleva \\ a los cielos..."
}

I ste epígrafe retoma una frase de la película El señor Ibrahim y las flores del Corán (2003), del director François Dupeyron. El sentido de la frase expresa de manera subjetiva que, al ceder el rol de sujeto al corazón, es este quien goza a plenitud del acto mismo de bailar, ya que, a través de la música, consigue ascender en búsqueda de una nueva fuerza y así el corazón del hombre alcanza otro nivel de comprensión de la realidad. En este sentido, el hombre, al danzar, aparte del movimiento corporal, de la modificación del gesto y del desenvolvimiento en el ambiente musical, se libera de la imposición que le generan las reglas sociales y culturales.

En primera instancia, empezamos por considerar a los griegos hacedores particularmente de dos figuras. Por un lado, la de Apolo como símbolo de la serenidad, la racionalidad y la mesura, y, por otro lado, la de Dionisio como símbolo de la embriaguez, el éxtasis y el exceso (hybris), lo que convirtió la presencia de Dionisio en un elemento que alteró el principium individuationis (principio de individuación), entendido como proceso de autorrealización del hombre configurado desde la presencia de Apolo. Por ello, en la visión dionisíaca se estableció una reconciliación del hombre con la naturaleza y con los otros hombres, y se revivió el idealismo del ser helénico que se refiere al culto de la liberación de los instintos. En dichos cultos, la divinidad ebria fomentaba el libertinaje en los adoradores; los volvía salvajes a través del vino y el desenfreno orgiástico, pues en este tipo de manifestaciones liberadoras era costumbre la evocación de gritos y alucinaciones paroxísticas.

La particularidad de estos cultos dionisíacos se ponía de manifiesto en las máscaras y los disfraces que guardaban relación con la fisonomía femenina: el rito a Dionisio era venerado en su mayoría por las mujeres, quienes, al participar en este, eran nombradas como Bók $\chi \alpha \iota$ (bacantes), ya que, inspiradas por Dionisio, trataban de imitar la danza delas ménades al llevar sobre sus cabezas coronas de laurel, vestidos hechos de pieles de animales o peplos, y en sus manos una antorcha hecha con madera de pinos envuelta en hiedras. Los hombres que concurrían en el rito, por el contrario, se disfrazaban como sátiros. Todos, aturdidos por el vino, danzaban al ritmo de los ditirambos e instrumentos musicales que acompañaron el grito ritual que invocaba a Dionisio "ievohé, evohé!", $y$, de esta manera, se incitaban unos a otros a participar del entusiasmo.

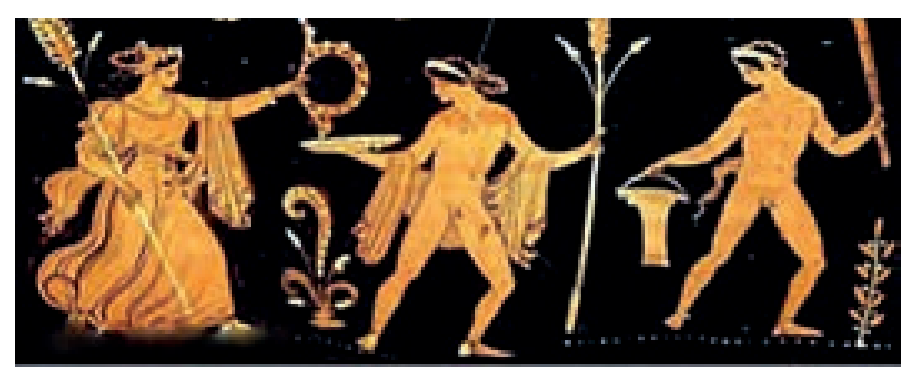

Ilustración 1. Dionisio acompañado de una bacante y un sátiro en el rito tradicional.

Sin duda, una de las disputas en la cultura griega aconteció con la aparición de Dionisio, que terminó por ser una amenaza para la misma. Por este motivo, Apolo, dios de las artes, intervino al equilibrar la desmesura (hybris) que había tomado posición debido al rito dionisíaco y, en contraste, constituyó la mesura. De ahí que la ceremonia dionisíaca se determinó como vulgar y peligrosa. Esto llevó al hombre a la negación de su voluntad, ya que se opuso a ma- 
nifestar sus instintos en la disipación dionisíaca. Al mismo tiempo nació en el hombre un sentimiento de culpa y arrepentimiento por el desenfreno, por lo que aspiró a tener una glorificación de la existencia, que se produjo, según Nietzsche “...(Mediante el arte)..." (1870, p. 14) y fue entonces cuando nació la tragedia, encarnada en un héroe que cayó en desgracia.

De este modo es necesario hacer una aclaración etimológica que adicione otra evidencia sobre la importancia de Dionisio para el desarrollo de este artículo, y es que sobre la tesis anteriormente mencionada respecto al origen del arte trágico aparece también un principio lingüístico en el que se fracciona el tér-

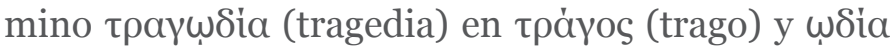
(canto), que guarda semejanza con el concepto canto del macho cabrío, por lo que se refiere al mito que da cuenta del nacimiento de Dionisio: Zeus tras la furia de Hera convirtió en un macho cabrío a su hijo y le llevó al monte Nysa donde quedó bajo la custodia de las ménades.

Aclarado lo anterior, se retoma nuevamente la negación de la voluntad como causa de la reconciliación del hombre con su yo. Luego de ello, el hombre comunicó de una manera adecuada sus instintos a través del uso moderado de los sonidos y el lenguaje gestual. Así, en primer lugar, el coro ditirámbico se acompañó con la intervención de instrumentos como el sistro, el shofar, los crótalos, el oboe, etc. Y con la música, articulada en la cultura griega desde la melodía simple y lineal. Además, la música así concebida "condujo a distintos modos y ritmos de carácter sustancialmente unívoco" (Comotti, 1999, p. 15).

En segundo lugar, el lenguaje gestual producido por movimientos aludió a signos tanto inteligibles como visibles, pues en la danza se personificó el símbolo en la realidad corporal y escénica. Allí la importancia no descansaba en la comprensión del gesto, sino en la interpretación del sentimiento simbolizado. De esta forma, apareció la reproducción intensa de los gestos mediante el simbolismo corporal y la energía física con los que el coro danzaba y con ello representaba los pensamientos de la naturaleza, idea que es retomada por Alfonso Rodríguez con relación a la poética aristotélica en cuanto a "la intención mimética de la naturaleza como fin esencial del arte" (2011, p. 148, ep1.1).

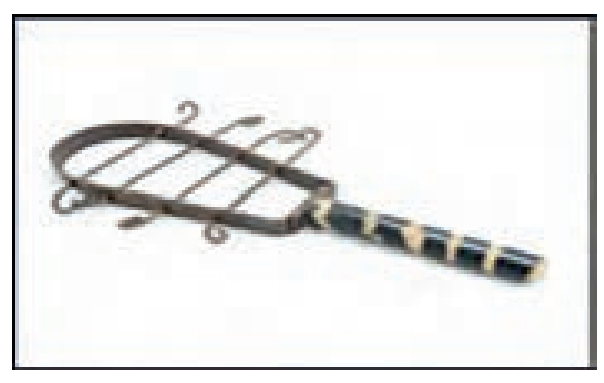

Ilustración 2. Sistro griego

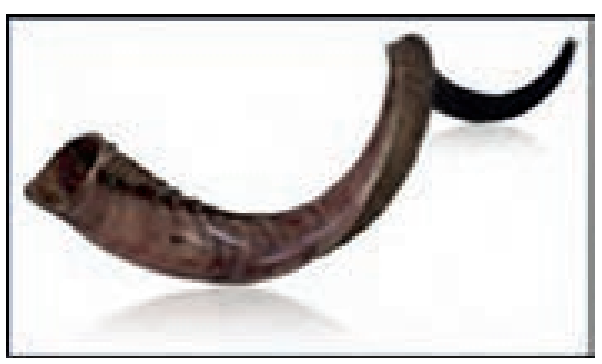

Ilustración 3. Shofar griego

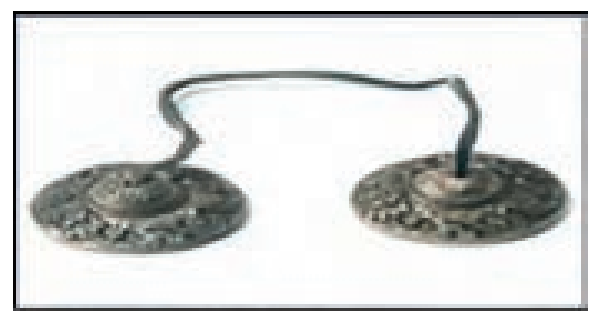

Ilustración 4. Crótalos griegos 


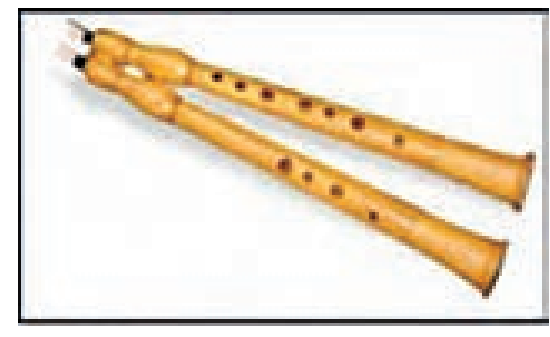

Ilustración 5. Oboe griego

\section{La danza en la polis griega}

La mención del coro lleva a examinar en segunda instancia su función en la polis griega. Ahora bien, una de las principales funciones del coro era competir en los agones o juegos olímpicos cada cuatro años. En Olimpia, el lugar donde se llevaban a cabo las competencias solo podían participar hombres que tuviesen por lengua el griego. Tal como señala Alfonso Rodríguez, "el Estado velaba por la formación de los integrantes de cada coro y les proporcionaba un aprendizaje completo en todas las materias artísticas que componían la actividad de poesía, música y danza" (2011, p. 154 ep 2). Así, la inserción de los jóvenes en los coros para las distintas festividades ajustó el sistema educativo, pues la danza coral fue una práctica importantísima en la visión formativa de la ciudad ideal. Por tanto, "carecer de educación, significa no haber practicado los coros; estar bien educado, equivale, en nuestra opinión, no solo a conocerlos, sino a hallarse bien instruido y ejercitado en ellos" (Platón, 1962, p. 39).

En este sentido se fomentó la participación e integración de los ciudadanos en la vida pública. Por ello, Alfonso Rodríguez, refiriéndose a Garelli Francois, aclara: "la formación circular del coro, que constituye el símbolo perfecto de la danza política, está fundada sobre las nociones de participación y homogeneidad"
(1995). Además, la danza, como medio para potenciar el desarrollo del cuerpo y la mente, fue concebida por los filósofos como un ejercicio equilibrado y armonioso, que indudablemente para Platón era una de las enseñanzas más profundas de comunicación ritual. En otras palabras, la danza brindaba un acercamiento íntimo a los dioses.

Hay que decir también que Alfonso Rodríguez reúne las danzas griegas en cuatro grupos: a) danzas rituales, agrícolas y guerreras, cuyo carácter era enteramente religioso; b) danzas de entretenimiento y teatrales, que semanifestaban principalmente para el deleite de los espectadores; c) danzas espectaculares, que tenían como rasgo un fin religioso. No obstante, mezclaban elementos propios del marco popular, y d) danzas espontaneas o improvisadas.

En cuanto al lugar en el cual los coros practicaban los entrenamientos de las danzas antes nombradas, es conveniente mencionar la palestra y el gimnasio, que se hallaban construidos en los márgenes de la ciudad, con columnas que rodeaban el terreno rectangular, acordonadas por habitaciones que en su interior contaban con salas espaciosas, baños y un lugar especial en el que se ungían los coreutas con aceite antes de recibir la instrucción por parte del poeta que dirigía los ensayos.

Se puede condensar lo dicho hasta aquí en que, en relación con el arte del coro, Platón indica que la finalidad de la danza " radica en imitar los caracteres por medio de representaciones en las que se ponen de manifiesto actos y circunstancias de toda especie" (1962, p. 41). En efecto, la consideración más significativa de la danza por parte de la sociedad griega se sitúa en el plano de la integridad y el placer, pues, sumado a un estímulo atrayente, es necesario que el deleite que produce la danza tenga como fin algún provecho moral. 


\section{La danza}

\section{en la tragedia griega}

Al llegar a este punto es necesario abordar la característica del coro en la tragedia griega, pues, a través de la figura que formaban los coreutas, la puesta en escena de las danzas "constituye un importante medio de expresión cultural” (Alfonso Rodríguez, 2011, p. 149). Sin olvidar el carácter religioso y coreográfico de las primeras danzas, el coro empleaba bailes y movimientos que contribuían al desarrollo de la estructura dramática: luego del prólogo en el que un personaje brindaba una explicación de la historia a los espectadores, el coro tenía lugar en la intervención conocida como párodos, en la cual entraba a la escena por los parodoi o pasillos y se acomodaba en el espacio semicircular llamado orchestra. Después proceden los episodios, en los que se representan los acontecimientos con la implicación de los actores y, finalmente, el éxodo que representa el fin de la participación de los coreutas.

Ahora bien, al fijarnos en la tragedia griega es necesario recordar el argumento de la misma: la tragedia representa la caída de un personaje importante. Este servirá como modelo para ejemplificar la siguiente descripción e interpretación de la obra Las bacantes de Eurípides (480-406).

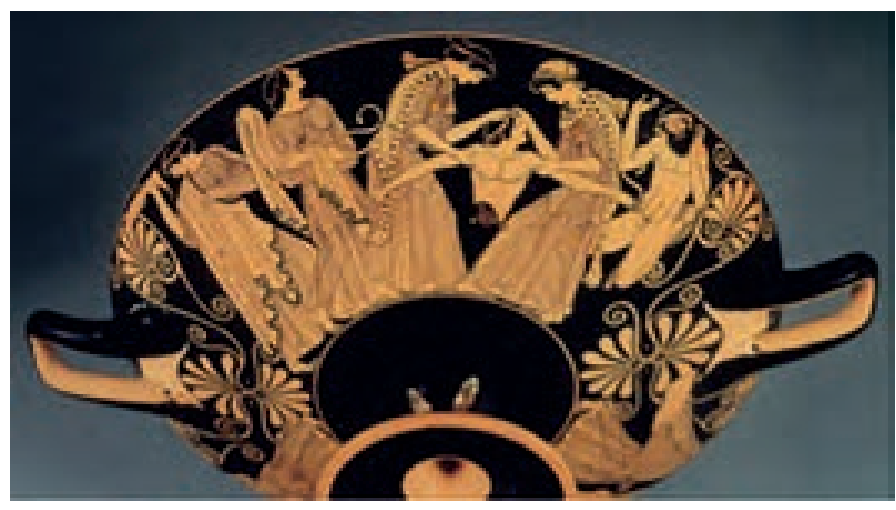

Ilustración 6. Las bacantes descuartizando a Penteo, 480 a. C.
El dios Dionisio era hijo de Zeus y de una mortal, Sémele. Tras sus viajes por toda Asia Menor, Dionisio llegó acompañado por un coro de bacantes a Tebas, ciudad en la que se negaron a su condición de dios. Las hermanas de su madre habían divulgado que Dionisio no era un dios. Por ello, Dionisio las hizo enloquecer y practicar también los ritos como bacantes. El rey Penteo, nieto de Cadmo, tampoco le ofrece libaciones. Finalmente Dionisio demuestra que él es un verdadero dios.

A continuación una breve paráfrasis de la obra en relación con los apartados 1 y 3 .

\section{“¿va a decir alguno que si no me avergüenzo de mi vejez, al ir a bailar con la cabeza coro- nada de yedra?" (1797, p. 356).}

Es claro que en la participación de la danza de las bacantes, tal como en el propio rito dionisíaco, se incluye la presencia de mujeres, hombres, ricos, pobres, ancianos y jóvenes, que tienen como único fin venerar al dios Baco.

\section{“... tomaríamos los tirsos, vestiríamos las pieles de corzo, y coronaríamos nuestras ca- bezas con brotes de yedra..." (1797, p. 355).}

Nótese cómo en el mundo artístico la representación dancística es posible gracias al uso de elementos como vestuarios, implementos y lugares específicos. Evidentemente los tebanos y las bacantes que danzaban en los montes aderezaban sus cuerpos con peplos hechos con pieles de corzos, coronas de yedras, tirsos de pino y, por último, cinturones con pieles de cervatillos y lobeznos. 
Respecto a la postura y acomodación del cuerpo en escena, que representa la visión del espectador, se muestra cómo un mensajero que cuidaba sus rebaños observa la posición de Autónoe, Àgave e Ino como corifeo, y se admira al presenciar la condición corporal de las bacantes.

\section{“- ¿Me asemejaré más a una bacante si tomo el tirso con la mano dere- cha, o con esta?" "-Hay que alzarlo con la derecha y mover a la vez el pie derecho" (1797, p. 387).}

Finalmente, tenemos aquí la única descripción que se refiere al movimiento del cuerpo que era practicado por las bacantes. Luego de que Penteo le mostrara a Dionisio su interés por contemplar a las mujeres, el dios le brinda una pequeña instrucción sobre cómo debe desplazar el tirso que tiene en la mano hacía el firmamento y, al mismo tiempo, ejecutar un movimiento con su pie derecho.

\section{Referencias}

Adrados Rodríguez, F. (2006). Música y literatura en la Gre cia antigua. Alicante, España: Biblioteca Virtual Miguel de Cervantes, p. 1-8. http:// www.cervantesvirtual.com/obra/ msica-y-literatura-en-la-grecia-antigua-0/

Comotti, G. (1999). Historia dela música (La música en la cultura griega y romana). (Piccardo, Fernández Rubén Trad.) Madrid, España: Turner Libros.

Eurípides. (1979). Tragedias III “Las bacantes”. Madrid, España: Gredos S. A.

Fernández Zoa, A. (2011). La danza en época romana: una aproximación filológica y lingüística. Universidad Complutense de Madrid. Departamento de Filología Clásica, pp. 52-68. Recuperado de: http:// eprints.ucm.es/ 13975/

Nietzsche, W. F. (1870). La visión dionisíaca del mundo (Sánchez, Pascual Trad.). Alianza editorial, pp. 1-20. Recuperado de: http://www.edu.mec.gub.uy/biblioteca digital/libros/ N/ Nietzsche\%20-\%20La\%20vision\%20dionisíaca\%20del\%20mundo.pdf

Platón. (1962). Las Leyes. Libro II. Madrid, España: Copyright, pp. 37-43.

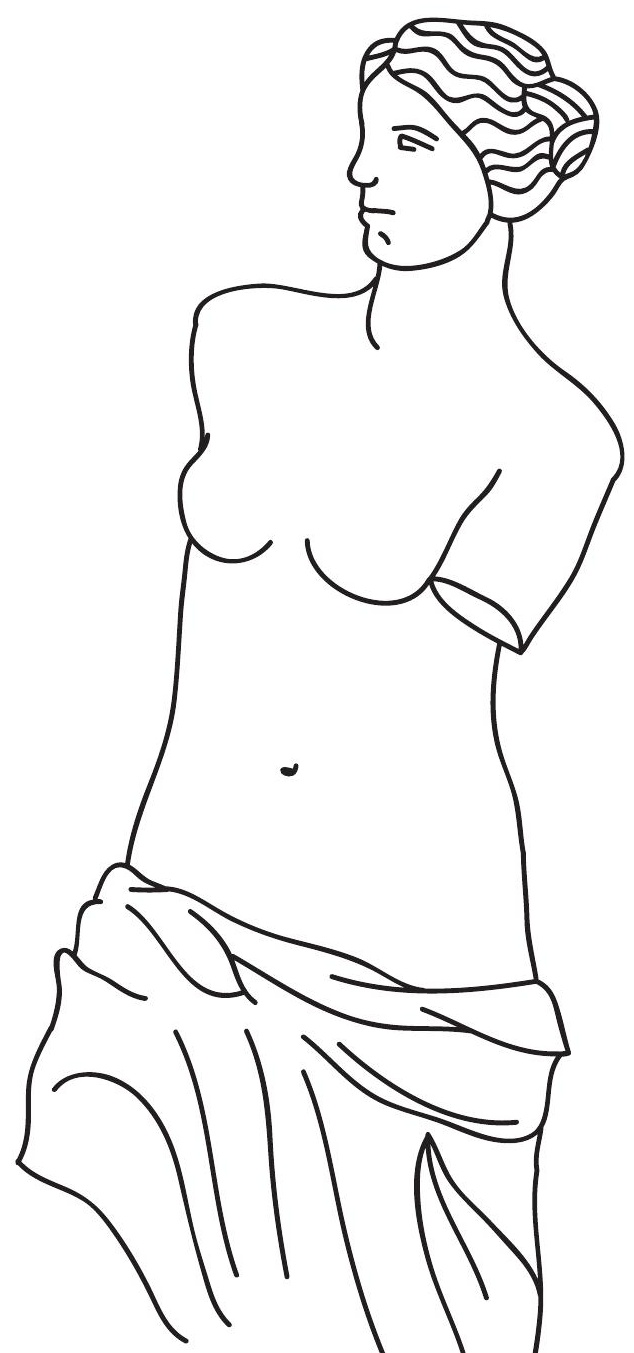




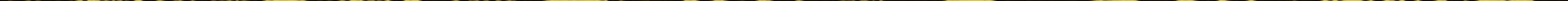




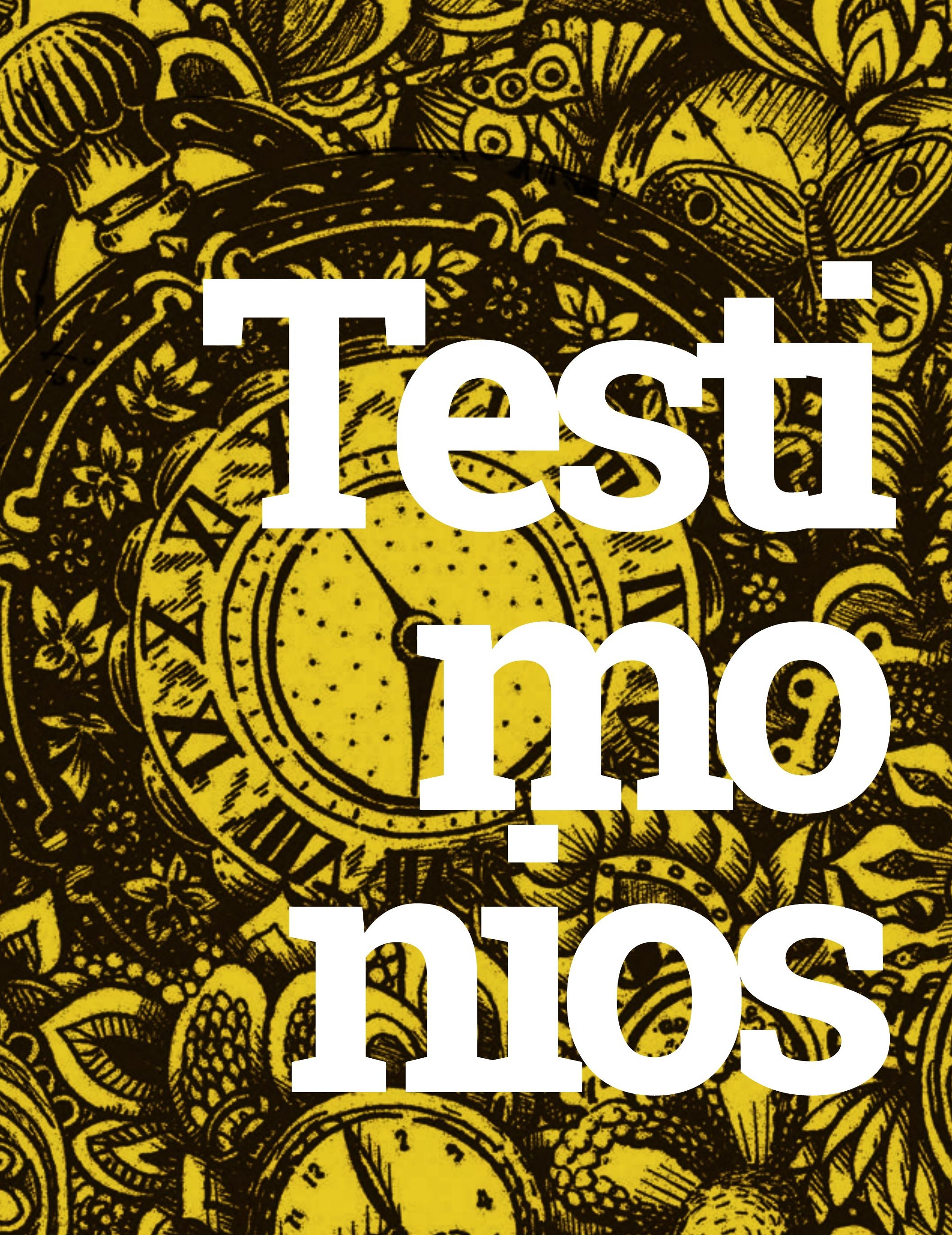




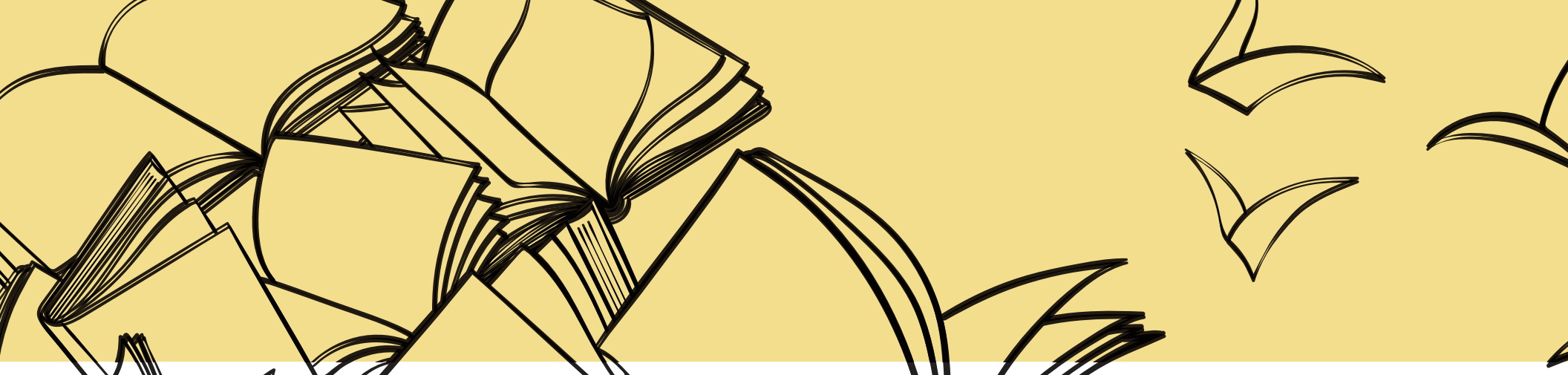

Educación

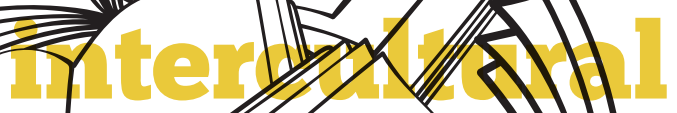

bilingüe: retos

por asumir

acciones

concretas por

realivar

Ingrid Paola Calderón Ramos ${ }^{1}$

"Ser libre no es solamente desamarrarse las propias cadenas, sino vivir en una forma que respetey mejore la libertad de los demás".

Nelson Mandela

1Estudiante del Doctorado en Educación, VI cohorte. Línea de investigación: Educación, cultura y sociedad. Facultad de Educación, Universidad Santo Tomás. Teléfono: 3213251061.

Correo electrónico: ingridpcalderon@gmail.com os temas relacionados con la educación en Colombia se encuentran de moda. Los últimos acontecimientos sobre identidad de género, diversidad y actualización de los manuales de convivencia, por sentencia T-478 de $2015^{2}$ de la Corte Constitucional, hicieron que padres de familia, docentes, rectores, estudiantes y ciudadanos del común centraran sus voces de apoyo o de protesta, sobre el manejo que se le está dando a la formación de los niños y las niñas en el contexto colombiano.

En el presente artículo, pretendemos reflexionar sobre algo que poco se ha mencionado, que es el trabajo que la educación debe emprender desde la diversidad y multiculturalidad que nuestro país tiene. Nos centraremos en las minorías étnicas, ya que el trabajo sobre identidad y respeto por el otro no debe dirigirse solo a la comunidad $\mathrm{LGBT}^{3}$, sino a todas las minorías vulneradas de nuestro país. Para ellos debe prevalecer el derecho a la igualdad, según lo reza la Constitución Política de Colombia:

\section{Artículo 13. Todas las personas nacen li- bres e iguales ante la ley, recibirán la mis- ma protección y trato de las autoridades y gozarán de los mismos derechos, libertades y oportunidades sin ninguna discriminación por razones de sexo, raza, origen nacional o familiar, lengua, religión, opinión política o}

2 Sentencia T-478 de 2015. Sistema Nacional de Convivencia Escolar en el que quede plenamente establecida la Ruta de Atención Integral para la Convivencia Escolar y que tenga un Sistema de Información Unificado de Convivencia en el que se garantice el respeto por la intimidad y confidencialidad de las personas involucradas.

3 Lesbianas, gais, bisexuales y personas transgénero. 
tanto, que nadie se preocupa por lo que realmente importa: la necesidad de conocer y entender la diferencia, la otredad 5 .

\section{La noticia en boca de todos}

Un show mediático se vive cada vez que salen por los medios masivos de comunicación (que, muy a nuestro pesar, tergiversan la información y no muestran tal cual como suceden las cosas) los altos índices de mortalidad infantil que se viven en La Guajira colombiana. Casi a diario, vemos cómo cientos de niños wayúu se encuentran en precarias condiciones de salud, desnutrición y abandono familiar, y se ve a los medios de comunicación buscando culpables, en vez de buscar responsables.

Algo importante por conocer es la cultura del indígena. Alguien alguna vez se ha preguntado: ¿Por qué el indígena no lleva a sus niños enfermos al hospital y prefiere que se mueran en sus brazos? ¿Saben qué le pasa a una mujer indígena si permite que otras personas se lleven a sus hijos de la ranchería? ¿Saben por qué desde tiempos remotos los indígenas wayúu tienen dentro de su cosmovisión la medicina tradicional? ¿Alguien entiende la diferencia del otro y su sentido de la vida? ¿Se han privilegiado espacios de interacción sociocultural en nuestro país? ¿Los colombianos conocen las raíces ancestrales de las comunidades indígenas? ¿Se privilegian en Colombia las cosmovisiones de las tribus indígenas?

5 La otredad es una postura epistemológica que explora discursivamente la imagen de las culturas que hicieron su espacio en la periferia u otros espacios culturales intermedios. Establece un saber geocultural, histórico, arqueológico, sociológico y etnológico sobre el otro, una metafísica donde las heterogeneidades y las diferencias se encuentran subsumidas en un lenguaje homogéneo, integradas en categorías sustanciales como "pueblo", "clase” y "nación”. Recuperado de: http:// otredadyalteridad.blogspot.com.co/
Todos juzgan desde afuera, pero nadie mira qué pasa casa adentro, qué sucede al interior de la comunidad con este tipo de prácticas ancestrales que no favorecen la salud de los niños, pero que se respetan y se cumplen, porque para ellos (no todos) el saber ancestral prima sobre el saber occidental y es totalmente respetable.

Las políticas educativas en Colombia, debieran estar tan alineadas a las tradiciones culturales y ancestrales de las comunidades, que muchas de esas tragedias, se pudiesen evitar, si se articulara una educación intercultural bilingüe. Pareciera que solo se busca imponer y estandarizar la educación, para obtener excelentes resultados en las pruebas nacionales e internacionales, sin entender y comprender la diferencia y la necesidad del otro.

\section{La realidad vs, el ideal}

Los alcances de la educación en Colombia han previsto que todos los niños y jóvenes tengan derecho a la educación, gracias al decreto expedido en el primer gobierno del presidente Juan Manuel Santos y la ministra de Educación María Fernanda Campo (año 2011), en el que se declaró la gratuidad univer$\mathrm{sal}^{6}$ para tres niveles de la educación en el país (preescolar, básica primaria y básica secundaria). Con este decreto, los padres de familia solo se deberían preocupar por matricular y enviar a sus hijos a las escuelas en toda la nación, ya que la gratuidad incluye materiales educativos, alimentación y transporte escolar, para garantizar que los niños vayan solo a estudiary los padres no se preocupen por nada más. En otras palabras, que la falta de recursos económicos no sea el problema para que los niños en Colombia puedan acceder al estudio.

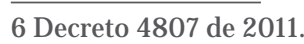


Sin embargo, las medidas desarrolladas por el Gobierno no han sido suficientes, ya que la cobertura y la calidad educativa en el país no van de la mano. Hay aspectos por reevaluar sobre cobertura en lugares distantes, como las aulas multigrado que reúnen a niños de varios grados con un solo docente, quien debe atender mínimo a 22 alumnos para poder ser nombrado y trabajar con ese grupo de estudiantes.

Otro problema grande es la educación contratada, pues su manejo es poco claro, respecto a los docentes que se deben contratar y al tiempo de duración en los colegios según el año escolar (algunos son contratados en abril o mayo), lo que hace poco regulares los procesos formativos con los niños. A ello se suma la demora en el inicio de los contratos por alimentación y transporte escolar que deben manejar las secretarías de educación y las gobernaciones, lo que es otro impedimento para que los niños puedan asistir a clase regularmente. No nos digamos mentiras, muchos niños no van al colegio a aprender, sino por el alimento que allí se les brinda, porque la miseria y la pobreza en la que viven es tal, que el único alimento recibido en el día puede ser el que se les dé en el colegio.

Podemos llamar perversas esas políticas en educación, que pretenden abarcar unas aspectos, pero que descuidan otros. ¿Qué puede ser más importante? ¿Estandarizar, subir los índices de las pruebas externas, articular programas que intervengan esas comunidades o privilegiar el derecho a la educación que se ganaron todos y cada uno de los ciudadanos colombianos, sin distinción de ningún tipo?

\section{La realidad \\ en las aulas indígenas}

Todas esas políticas educativas están pensadas para las personas del común, para ciudadanos colombianos que viven en las grandes urbes o en ciudades pequeñas con fácil acceso. Debemos referirnos a la realidad de cientos de comunidades que viven apartadas, en sitios con grandes distancias entre comunidad y comunidad. Y lo menos alentador es que, por la geografía colombiana, no existe transporte público convencional, sino solo transporte en motos o en los vehículos del transporte escolar, que son de las mismas autoridades indígenas de las comunidades.

Para contrarrestar ese déficit en la educación, se generó el Decreto $2500^{7}$, que habla sobre la educación propia y sobre los alcances que esta debe tener. Sin embargo, existen muchos vacíos que no se logran llenar con el decreto.

Así las cosas, ¿cómo pretender que una madre de familia lleve a su hijo recién nacido a un control de crecimiento y desarrollo? ¿Cómo pedir que vaya y lo vacune las veces que se estipula en el carnet de vacunación? ¿Cómo esperar que le dé suplementos nutricionales, cuando lo poco que comen lo logran gracias a la venta de chivos o a las mochilas que tejen y que pocos pagan bien? ¿Cómo gastar en un transporte lo que sirve para comer durante varios días?

¿Cómo pedir que cumplan una minuta y una tabla nutricional, cuando lo que mandan a los comedores escolares es yuca, plátano, arroz y demás harinas y pocas veces se encuentran las proteínas, granos, frutas y verduras que sean un real complemento alimenticio?

Cuando los colombianos del común y sus gobernantes comprendan la realidad fuera de las cuatro

7 Decreto 2500, Creación de Mesas Técnicas Indígenas y del SEIP (Sistema de Educación Indígena Propio). 
paredes de sus oficinas, entenderán que el país es diverso y muy particular, y se convencerán de que se deben gestar todas las políticas desde esa mirada diferentey respetuosa por el otro. Es necesario entender que las leyes y los principios no aplican para todos, porque en la diferencia está la riqueza de nuestro país.

Los entes de control deben privilegiar los usos y costumbres de las minorías, pero vigilar y castigar con todo el rigor de la ley a quienes se roban el dinero girado a los niños e impiden suplir sus necesidades básicas. El Gobierno debe ser garante de la adecuada utilización de esos recursos para que no se desvíen a las manos de unos pocos.

\section{La. propuesta.}

La educación intercultural bilingüe ha de privilegiar todas esas diferencias que nos hacen ciudadanos colombianos. El derecho a la vida y a la educación han de ser ejes centrales de la política pública; han de pensarse las cosas desde la realidad del país y no desde ideales etéreos. Cuando se piensen las necesidades del país desde el contexto cercano, se pensarán políticas acertadas y reales, que suplirán las necesidades de todos y de cada uno. En ese momento también se hablará de paz, la paz que se tiene cuando todos los derechos se cumplen y se respetan.

La estandarización y homogenización pervierten la realidad y son excluyentes. Todos tenemos los mismos derechos y deberes, entre ellos a ser diferentes y a respetar la otredad. Cuando en el país entendamos todo ello, se pensará desde la diversidad no solo sexual, sino en todas las diversidades, y encontraremos el punto para unirnos y trabajar más y mejor por la calidad de vida de todos y no de unos pocos.

Los alcances de la educación privilegiarán los espacios donde la educación intercultural bilingüe encuentre las diferencias y similitudes que han de mostrar los avances significativos que deben tener los diferentes actores de la educación. Es necesario prever que los cambios en educación deben ser graduales y acertados. Las metas que el Gobierno establezca deben basarse en toda la realidad y apuntar a resolver las problemáticas actuales. No basta decir que se quiere ser el país más educado en el año 2025, sino trabajar para ello.

La colonización de las minorías debe detenerse y deben respetarse de una vez por todas las marcadas diferencias que poseen, ya que sus culturas así lo exhiben desde sus ancestros. Los procesos hegemónicos, de dominación y de dominados, deben abordarse desde los derechos de los ciudadanos. Las brechas de inequidad

y de desigualdad social en Colombia y América Latina deben trabajarse en el aula. 



\section{(Re)construir identidad y resignificarse culturalmente: una ambición para el hombre muisca \\ contemporáneo de Bosa \\ J orge Hernán Rincón Ochoa ${ }^{1}$ y Laura
Camila Ruano Buitrago ${ }^{2}$}

1 Profesor de la Facultad de Gobierno y Relaciones Internacionales, División de Ciencias J urídicas, Universidad Santo Tomás. Correo electrónico: jorgerincono@usantotomas.edu.co

2 Estudiante de la Facultad de Gobierno y Relaciones Internacionales, División de Ciencias J urídicas, Universidad Santo Tomás.

Correo electrónico: lauraruano@usantotomas.edu.co

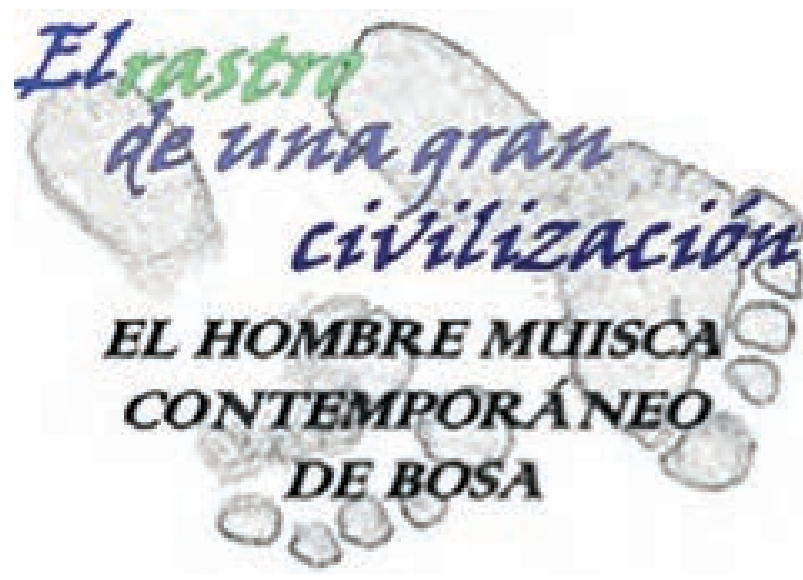

Elaboración propia.

l Cabildo Muisca de Bosa, reconocido en el año 1999 mediantela Resolución 4047 del Ministerio del Interior de Colombia, es una entidad pública especial cuyos integrantes pertenecen a la minoría étnica muisca que habita en la localidad de Bosa de la ciudad de Bogotá D. C. El cabildo ha comenzado la ejecución de procesos destinados a recuperar y a afianzar la identidad cultural de sus miembros desde principios del presente siglo.

Con la intención de abordar las causas que estimularon el inicio de los procesos de resignificación cultural y contribuir a los intentos académicos de abandonar la paradoja del discurso común, que entiende lo muisca como cultura del pasado, el propósito de este artículo es reflexionar sobre los principales acontecimientos implicados en la formación del Cabildo Muisca de Bosa desde finales del siglo XX e inicios del siglo XXI, que se configurarían como elementos clave en los procesos de resignificación cultural.

El presente documento estará estructurado en dos partes. En la primera, se verá un repaso general de las propuestas del teórico cultural y sociólogo Stuart Hall sobre reconstrucción de identidad, que han sido utilizadas para explicar los procesos de transforma- 
ción y, posteriormente, de resignificación cultural de varias comunidades campesinas latinoamericanas durante el año de 1999, momento en el cual muchas de ellas renunciaron a una organización basada en categorías ligadas a formas de producción, buscando recuperar modos ancestrales de organización política que las llevaron a convertirse en comunidades indígenas. En la segunda parte, se describirán los acontecimientos implicados en la formación del Cabildo Muisca de Bosa y se hará una reflexión acerca de si estos mismos acontecimientos pueden ser usados como elementos clave en los procesos de resignificación cultural.

\section{La resignificación cultural y la (re)construcción de identidad.}

Suele entenderse como resignificación cultural las acciones destinadas a buscar nuevas formas de recuperar y afianzar la identidad étnica de pueblos con rasgos culturales que están a punto de desaparecer o que ya están en desuso, pero aún quedan en la memoria de los mayores de la comunidad (Puente, 2007). Resignificar no implica un cambio cultural (aculturación), sino la reconstrucción de un conjunto de competencias sociales que amplía el espectro de significaciones posibles de la cultura indígena (Martínez, 2007). Es decir, que los procesos de resignificación cultural están destinados a la reconstrucción de la identidad étnica, pero este último concepto - fuertemente vinculado a la noción de indígena- ha pasado a conformar el léxico cotidiano tendiendo a crear la ilusión de que existe un consenso acabado sobre sus contenidos. No hay nada más alejado de la realidad. En la práctica es constantemente revisado y empleado bajo interpretaciones específicas, en función de los intereses puestos en juego (Bazurco, 2006).

La identidad se centra en ese punto donde se cruzan una serie de diversas transformaciones en la sociedad y una serie de discursos relacionados (Hall, 2010). Laidentidad surge como una circunstancia sin resolver. Supone varios discursos que se cruzan. Uno de estos discursos está enfocado en asociar la identidad con la etnicidad, lo que para Bernal y Knight permite definir la identidad étnica como un tipo de ideas sobre el yo (autoideas) relacionadas específicamente con uno mismo como miembro de un grupo étnico (Bernal \& Knight, 1993). En lugar de referirse a la comprensión de la etnicidad de otros, la identidad étnica está relacionada con el conocimiento de uno mismo y de pertenencia personal como miembro de un grupo étnico, lo que genera conocimientos, valores, conductas y sentimientos que tienen implicaciones directas en esta pertenencia y que evidencian que la identidad es una construcción del sujeto.

Para García Canclini, la identidad es una narrativa que se construye, un relato en construcción continua y no una esencia dada de una vez y en forma definitiva. Es, a su vez, una narrativa construida por y entre los diversos actores sociales, pero que se realiza en condiciones desiguales, debido a las relaciones de poder que intervienen (García, 2002).

Para Stuart Hall, existen dos formas distintas de entender el proceso de construcción de la identidad. Como revelación del 'ser', en tanto manifestación de la mismidad 3 , y como sentido de la continuidad. Es decir, demostración de lo que siempre se ha sido, pero con consciencia temprana de ello. $\mathrm{O}$, por el contrario, como un 'devenir': como producción de diferencia y expresión de la discontinuidad (Bazurco,

3 Idea que apela a una unicidad del ser y no a la condición que adquiere por el hecho del devenir. 
2006). Dejar de ser lo que se supone ha sido y revelar realmente lo que se es.

\section{Propuestas teóricas sobre (re)construcción de identidad}

Después de exponer el porqué es posible(re)construir identidad, se dará paso a explicar el oómo. El antropólogo Martín Bazurco Osorio se basa en los estudios culturales de Stuart Hall con la intención de explorar teóricamente los procesos de (re)construcción de identidad de las comunas indígenas de Santa Elena, Ecuador. Resulta necesario admitir que el análisis teórico de Bazurco es en parte adaptable como base para explicar los acontecimientos formativos queson claves para los procesos de resignificación cultural del cabildo, puesto que ambos casos, tanto el Cabildo Muisca de Bosa como las comunas indígenas en la provincia de Santa Elena, fueron comunidades campesinas latinoamericanas que renunciaron a una organización productiva, buscando recuperar formas propias y ancestrales de organización política y convirtiéndose en comunidades indígenas. De modo semejante, se expondrán dos de las tres propuestas teóricas sobre construcción de identidad que Bazurco delimita: identidad como diáspora e identidad como hibridación.

La idea de la identidad como diáspora pretende enfatizar un dislocamiento que puede ser tanto espacial como temporal (Bazurco, 2006). En este último sentido, se refiere a la permanencia de una rehusada unión con el pasado. Un pasado que se presenta posiblemente en ruinas y es idílico, y además, no se puede retomar.

El sentido espacial del dislocamiento es más evidente: alude a los movimientos poblacionales, forzosos o voluntarios que imponen contextos nuevos para la reproducción cultural (Bazurco, 2006). La diáspora es el destino cuando no hay vuelta atrás, cuando se han perdido las raíces. La comunión con el pasado (el origen común) se debe rearticular en el presente, como proyección ideológica y programática. Las identidades 'diaspóricas' están articuladas, más que por la existencia de un pasado común, por la continua reafirmación de la diferencia (Bazurco, 2006). Esta diferencia se intensifica a través de un "esencialismo estratégico". Este concepto, propuesto por Spivak, señala que, pese a la aparente igualdad entre personas que habitan un mismo espacio, llegado el momento de reclamar reconocimiento frente al Estado, las diferencias se hacen explícitas (Spivak, 1988).

La identidad como hibridación comúnmente se refiere a la creación de nuevas formas transculturales en las zonas de contacto generadas por la situación colonial u otros contextos de interculturalidad (Bazurco, 2006). Se trata de un término relacionado con lo que Homi K. Bhabha denomina third space of enunciation ${ }^{4}$, en donde ocurren las articulaciones culturales de las zonas de contacto intercultural (Bhabha, 1994). Estas se convierten en sí mismas en 'la realidad cultural' por excelencia y por encima de cualquier reclamo de 'pureza' o 'autenticidad' esenciales (Bhabha, 1994). De allí se desprende que en las actuales circunstancias no habría más realidad cultural que la hibridez, ya que es inimaginable pensar en una realidad cultural como aislada o pura (Bhabha, 1994).

4 Tercer espacio de enunciación. 
Acontecimientos implicados en la formación del Cabildo Muisca de Bosa desde finales del siglo XX e inicios del siglo XXI

En 1850, el artículo 4 de la Ley del 22 de junio disolvió el Resguardo Indígena de Bosa como parte de un plan de desindigenización de la capital, el cual concluyó en 1886 (Secretaría General de la Alcaldía Mayor de Bogotá, 2011).

Con la disolución y repartición del resguardo de Bosa, dicha zona pasó a ser considerada como vereda, con lo cual se le restaba importancia y categoría como territorio autónomo, lo cual disminuía el poder e influencia de los muiscas en la Sabana de Bogotá. Adicionalmente, la extinción de los resguardos traía consigo la intención de personas ajenas a la comunidad por acaparar más tierras, especialmente las tierras de la Sabana, que eran las más fértiles de la época (Castaño, 2014).

Con esta situación, los muiscas comenzaron a decaer en sus actividades propias. Además, permitió el aumento de un proceso de mestizaje que condujo a la pérdida de costumbres y tradiciones al existir una presencia mayoritaria de no indígenas entre la comunidad (Castaño, 2014).

Aproximadamente cien años después de la disolución del resguardo, a finales del siglo XX, se produjo una repentina consciencia de las familias Neuta, Tunjo, Chiguasuque, Orobajo, Buenhombre, J uyo y Fitata sobre lo que pudo ser su pasado (Fernández, 2014). Este proceso tuvo como marco las problemáticas por invasión legal e ilegal de territorio, la contaminación de fuentes hídricas y la imposibilidad de ejercer alguna actividad agraria. Hay un hecho específico que incitó a estas familias a pensar sobre su pasado. Según una entrevista hecha por el politólogo Mauricio Fernández Castillo, este fue el relato de una de las fundadoras del Cabildo:

Bueno, el caso es, de verdad, muy dramático. Viendo en el momento que, afortunada o desafortunadamente, murió un sobrino y mi cuñado le colocó abogado. El abogado que consiguió mi cuñado, cuando vio los apellidos, que Neuta, que Chiguasuque, que todo, él estaba o era, él es un historiador; me parece que sellama Julio Balseiro, el señor. Entonces, él le dijo a él que tratara ese caso de abogado, del abogado, por lo cultural, que éramos nosotros. Entonces ahí se sumaron como unas tres o cuatro familias de los mismos familiares de mi sobrino y ahí nació el cabildo. De ahí empezaron a mirar, a formar, a hacer reuniones; tres, cuatro, cinco, diez familias, hasta que llegaron al acuerdo a... Él los ayudó hasta formar las autoridades; que tenía que haber un vice... Un gobernador, un vicegobernador. Esto hicieron, a donde él llevó toda esa papelería, para llegar a conformar el cabildo. De ahí para allá, se fueron sumando, sumando, sumando familias y ya fue cuando empezaron a hacer los trámites del Ministerio del Interior para que nos reconocieran, y ahí nació. Ya después cada año, o mejor dicho, aquí cada año se cambia de autoridades. Entonces ya después ya surgió que otro y otro. O sea que, ya viene fue cuando llegó Reinel, que Reinel prácticamente hace también lo que está fundado el cabildo. O mejor dicho, mi cuñado, porque dijeron que tenía que prepararse una persona para llegar allá; entonces mi cuñado hasta le pagó la preparación para que llegara. 
Entonces llegó Reinel y ahí ya nació el cabildo, ya se conformó. También estuve en la conformación de ASCAI (Asociación de Cabildos Indígenas); también fuimos varios alcaldes de acá, que fuimos con Reinel y otras personas que también fuimos fundadoras de ASCAI (entrevista sin editar a Isabel Neuta, por Mauricio Fernández Castillo, 2014).

La iniciativa de este abogado e historiador conllevó el intento de organizar un cabildo indígena con la colaboración de intelectuales externos: un antropólogo, un sociólogo, dos historiadoras y un periodista (Panqueba, 2011).

En 1998 se instaló un Consejo de Ancianos y un Cabildo Provisional, mientras se realizaba el "autoestudio" para acreditar ante el Ministerio del Interior la condición de indígenas por quienes así se reconocen y habitan el territorio muisca de Bosa. El estudio consistió en entrevistar a personas mayores bajo la asesoría de las personas citadas, lo cual en principio perfiló esta reinvención como un híbrido académico.

En este proceso confluyeron metodologías de investigación características de estudios históricos, antropológicos, etnológicos y jurídicos, con la finalidad manifiesta de demostrar la identidad indígena frente al Estado colombiano. Las estrategias asumidas buscaban el reconocimiento legal dela comunidad muisca como parte de los pueblos indígenas de Colombia. Otro objetivo era conseguir la titulación colectiva de tierras bajo la figura de resguardo indígena. Con esta figura se hubiera logrado que el Estado colombiano transfiriera recursos económicos a la comunidad en razón a la cantidad de población (Panqueba, 2011).

Hubo dos temas de la cotidianidad que fueron el cimiento para esta reorganización indígena: la autoidentificación de algunas personas como muis- cas y el reconocimiento por parte de las Juntas de Acción Comunal (J AC) de las veredas San J osé y San Bernardino de la localidad de Bosa.

Posteriormente, los cimientos "académicos" plasmados en el autoestudio describían aspectos que los relacionaban con un pasado indígena, como la existencia de apellidos muiscas del tipo Chiguasuque, Tunjo, Neuta, Fontiva, Cobos, Orobajo, entre otros. El documento, además, fundamenta la identidad "claramente indígena" por la descripción de ocupaciones agrícolas, la cría de aves de corral, manifestaciones lúdicas como el juego del tejo o turmequé y el bocholo. También algunas costumbres alimentarias y un manejo particular del español que pretende resistir a la pérdida de la lengua chibcha (Panqueba, 2011).

Este estudio condujo a que el Cabildo Muisca de Bosa fuera reconocido en el año de 1999 mediante la Resolución 4047 del Ministerio del Interior de Colombia.

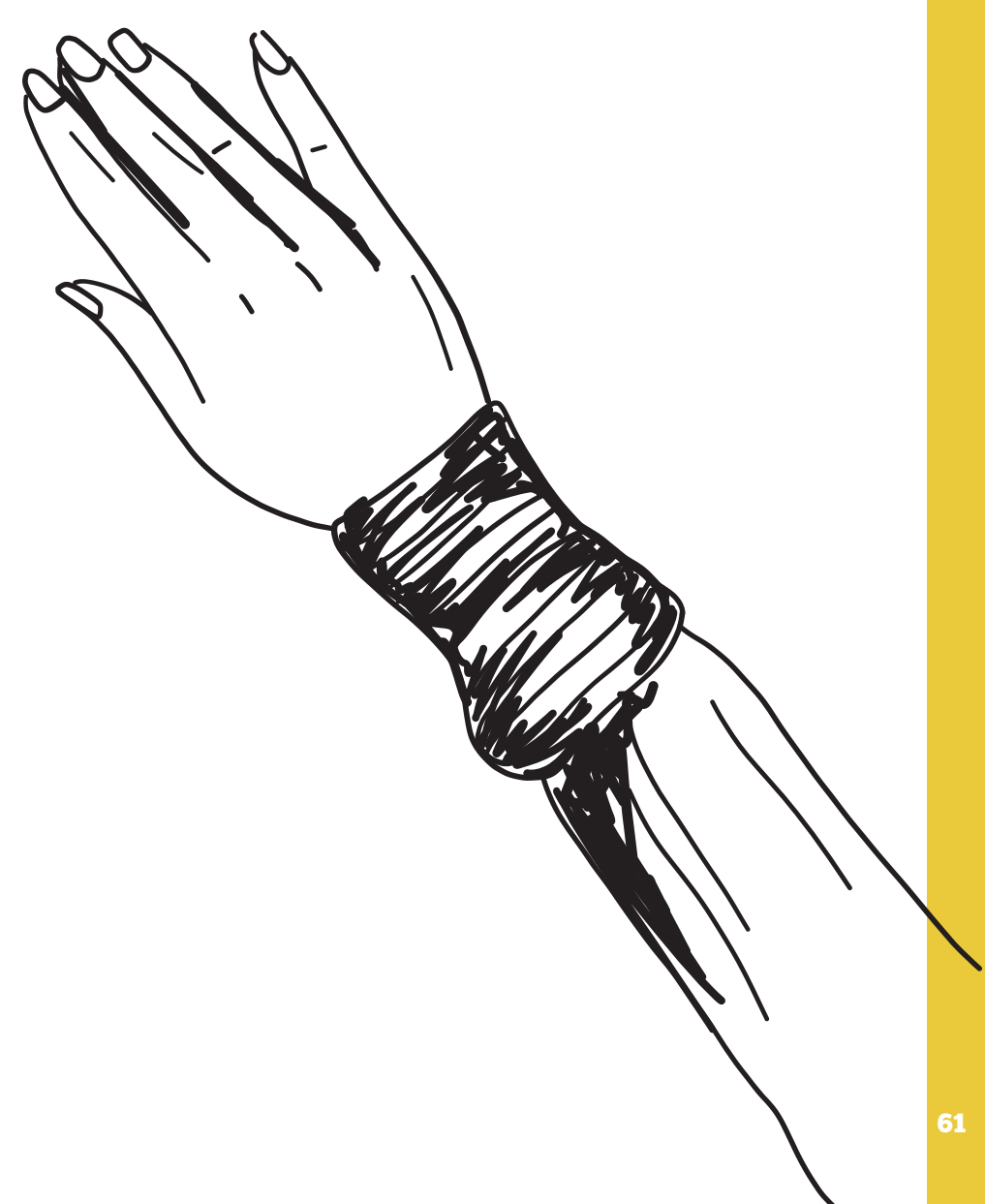


Los acontecimientos

implicados en la formación del Cabildo Muisca de Bosa como elementos clave en los procesos de resignificación cultural

\section{Reflexión final}

"El doctor Peñalosa dijo que si nosotros no teníamos los taparrabos y no estábamos pintados empelotos no éramos indígenas. [Pero] nosotros reconocemos que somos indígenas por la originalidad que tenemos".

Beatriz Chiguasuque

En esta parte se pretende reflexionar sobre la relación entre los acontecimientos implicados en la formación del cabildo y las propuestas teóricas sobre reconstrucción de identidad. Ambas consideraciones han sido desarrolladas anteriormente y se observará cómo confluyen en los procesos de resignificación cultural.

La idea de la identidad como diáspora pretende enfatizar un dislocamiento que puede ser tanto espacial como temporal. Este es evidente para el caso de Bosa, dado que, desde la disolución del resguardo, las tierras de las veredas San J osé y San Bernardino no pertenecen ni son habitadas por una sola comunidad: han sido vendidas y revendidas, despojadas y recuperadas, invadidas y contaminadas. Es una creencia que desde que San Bernardino y San J osé pasaron a ser veredas, las familias que ahora se reivindican como "descendientes directos" de los in- dígenas muiscas perdieron su "legítima" propiedad sobre estas tierras a través de múltiples procesos comenciales e ilegales. Es entonces, como se atestigua, un dislocamiento espacial.

Desde que se concluyó la disolución del resguardo en 1886, los indígenas muiscas que sobrevivieron a la explotación económica empezaron a hacer parte del campesinado de Bosa. Perdieron la lengua, las creencias, las costumbres y las prácticas originarias que habían podido sobrevivir hasta el momento. Esta es la evidencia de un dislocamiento temporal. En la entrevista a Isabel Neuta, quien es una de las personas mayores de la comunidad, afirma no saber sobre su pasado, ni sobre el origen de sus apellidos, ni el porqué de su ubicación actual.

El pasado del cabildo está en ruinas y es idílico: es un pasado que no se puede retomar, sino reconstruir. De tal forma que la comunión con el pasado (el origen común) se debe rearticular en el presente, como proyección ideológica y programática, tal como se pretendió con el estudio queles dio el aval de cabildo, un experimento académico realizado por los profesionales en ciencias sociales ya mencionados.

El cabildo tiene como base la continua reafirmación de la diferencia, que se evidenció precisamente cuando se tuvo una noción mínima de que podían ser indígenas y no parte del campesinado camuflado con la urbanización, obteniendo ciertos beneficios como el reconocimiento estatal, ciento trece años después de desmembrado el resguardo. Acá encontramos el "esencialismo estratégico" de Spivak: pesea la aparente igualdad entre personas que habitan un mismo espacio, llegado el momento de reclamar reconocimiento frente al Estado, las diferencias se hacen explícitas.

Con relación a la segunda teoría, la identidad como hibridación, se pretende demostrar que el inicio de los procesos de resignificación del cabildo no 
pueden estar ligados a una concepción de pureza cultural, ni de costumbres nítidas originarias que se deberían traer al presente. Tampoco de la plena consciencia humana de lo que sus antepasados fueron o pudieron ser, sino reconociendo la mezcla constante de elementos de diverso origen cultural y las maneras desiguales de apropiación, combinación y transformación de los elementos simbólicos enriquecedores de la identidad, puesto que se habita en un medio urbano, que incuba más vehemente la globalización.

Estos acontecimientos: el suceso vivido por Isabel Neuta, la identificación de las familias por parte de profesionales en ciencias sociales, el reconocimiento de las familias de sí mismas como indígenas, el estudio para la formación del cabildo y el reconocimiento de este por el Ministerio del Interior, son elementos clave en esta comunidad para el proceso de resignificación cultural, puesto que todos estos detalles se desprenden de la causa de resaltar la diferencia y reconstruir identidad.

Por consiguiente, el construir identidad muisca y resignificarse como hombre muisca es una ambición para unos hombres contemporáneos de Bosa.

\section{Referencias}

Bazurco, M. (2006). "Yo soy más indio que tú”. Resignificando la etnicidad. Quito, Ecuador: Editorial Abya Yala.

Bernal, M. E., \& Knight, G. P. (Eds.). (1993). Ethnic identity: Formation and transmission among Hispanics and other minorities. New York, NY: SuNY Press.

Bhabha, H. K. (1994). El lugar de la Cultura. Buenos Aires, Argentina: Manantial.

Cabildo Indígena Muisca de Bosa (2001). El pueblo indígena muisca de Bosa tan vivo como la chicha. Bogotá: Comunidad Indígena de Bosa.

Castaño, D. (2014). La consulta previa como mecanismo de defensa de los derechos colectivos de los pueblos indígenas. Estudio de caso: Cabildo Muisca de Bosa (20082012). Facultad de Ciencia Política y Gobierno, Universidad del Rosario, Bogotá D. C., Colombia. Recuperado de: http:// repository.urosario.edu.co/ bitstream/ handle/10336/8897/1012394592-2014.pdf?sequence $=3$

Fernández, M. (2014). La resignificación cultural mediante la acción colectiva frente a la expansión urbana. Un estudio diagnóstico sobre la problemática del territorio del Cabildo Indígena Muisca-Bosa período 1999-2013. Facultad de Ciencia Política y Gobierno). Universidad del Rosario, Bogotá D. C., Colombia. Recuperado de: http:// hdl.handle. net/ 10336/ 8680

García, N. (2002). Latinoamericanos buscando lugar en este siglo. Buenos Aires, Argentina: Paidós-SAICF.

Hall, S. (2010). Sin garantías. Trayectoria y problemáticas en estudios culturales. Popayán, Colombia: Envión Editores.
Recuperado de: http:// perio.unlp.edu.ar/ catedras/ system/ files/stuart_hall_-_sin_garantias.pdf

Martínez, R. (2007). Vivir invisibles. La resignificación cultural entre los otomíes urbanos de Guadalajara. México D. F., México: Publicaciones de la Casa Chata.

Morales, M. (1998). Cuestión étnica y debateinterétnico: ¿Qué ha pasado y qué pasa ahora en Guatemala? Guatemala: Instituto Internacional de Literatura Iberoamericana. Recuperado de: http://gateway.proquest.com/openurl?ctx_ ver=Z39.88-2003\&xri:pqil:res_ver $=0.2 \& r e s \_i d=x r i: i l c s-$ us\&rft_id=xri:ilcs:rec:abell:Ro3158684

Panqueba, J. (2011). Indígenas del “otro” lado de Bogotá, Colombia: semblanza sobre sus memorias cotidianas e identificación histórica. Desacatos, (35), 131-148. Recuperado de: https://doaj.org/article/ddced72f54af466f847a66de3571e638

Puente, M. I. (28 de marzo de 2007). Bordando una identidad. Conferencia llevada a cabo en la exposición "Sonora, luces de tierra incógnita. Pueblos indígenas del noroeste de México". Instituto Nacional de Antropología e Historia, México D. F.

Secretaría General de la Alcaldía Mayor de Bogotá. (2011). Ley 3 de 1850 nivel nacional. Recuperado de: http:// www.alcaldiabogota.gov.co/sisjur/normas/Norma1.jsp?i=12660

Spivak, G. C. (1988). Can the subaltern speak? Can the subaltern speak? Reflections on the history of an idea, 21-78. 


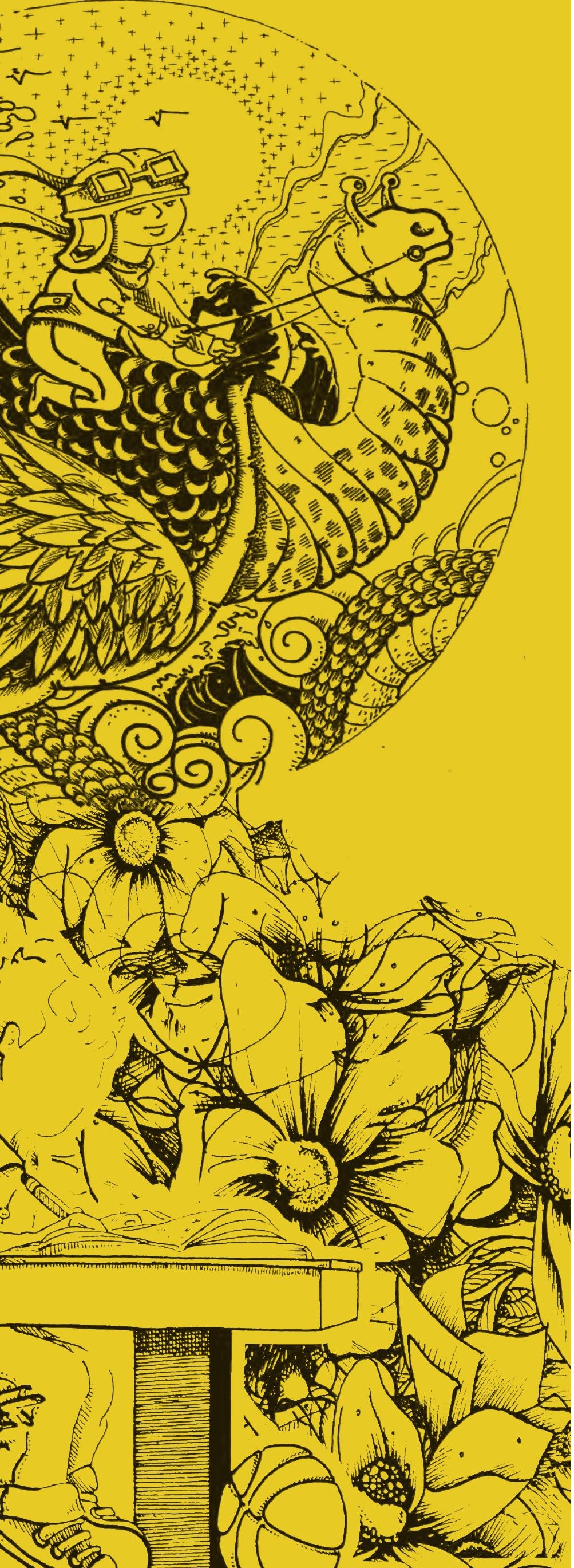

\section{La cartilla}

escolar en

Rafael Pombo y

Walter Benjamin

Marisol Moncada Vivas ${ }^{1}$

1 Egresada de la Licenciatura en Filosofía y Lengua Castellana de la

Facultad de Filosofía y Letras de la Universidad Santo Tomás, Bogotá, y

estudiante de la Maestría en Filosofía Latinoamericana. 
La cartilla escolar ha tenido un lugar especial en nuestra niñez, porque con ella aprendimos a escribir, a leer y nuestros maestros hacían uso de esta con el fin de enseñar y formarnos mediante una ética moralizante, la cual más adelante aplicaríamos en nuestro entorno. Sin embargo, la cartilla no contiene una única finalidad ante las distintas perspectivas, como la de Rafael Pombo, quien consideraba que esta era un producto de la observación de los rasgos de carácter y de las aptitudes distintivas de la infancia; y la de Walter Benjamin, quien afirmaba que la cartilla desarrolla en los niños una ética no moralizante, la cual les permite preservar su tierna y reservada fantasía, porque es ahí donde crean y hacen su mundo a su gusto, en el cual el adulto no debe intervenir, sino mantener sus capacidades de imitar, jugar y de ser críticos frente a lo que les rodea. Lo anterior conlleva a exponer dos pensamientos distintos que conducen a comprender la pedagogía ética en Pombo y Benjamin.

Este artículo presenta parte de la investigación sobre "La pedagogía ética en los cuentos pintados, fábulas y verdades de Rafael Pombo desde la perspectiva metodológica de Walter Benjamin". Esta pedagogía se evidencia en la citada obra de Pombo, mediante narraciones poéticas, en donde el verso no es utilizado como simple enunciado que forma la unidad de un poema, sino como instrumento pedagógico, permitiéndole al niño descubrir los valores éticos de la sociedad.

La indagación de esta problemática tiene la intención de mostrar que Pombo no solo es un poeta romántico, sino un pedagogo que impulsó las costumbres y la formación moral en niños y jóvenes. Benjamin, igual que Pombo, se caracteriza por considerar las relaciones entre juego y literatura infantil con el objetivo de darle un giro a la pedagogía, donde infantes y jóvenes hacen de su imaginación un camino de libertad y transformación frente al mundo y a la vida.

De ahí que la idea sobre la cartilla en Pombo alude al método de semejanza que se adelanta a las actuales teorías sobre el papel que juega la ilustración en los "libros para niños". Sobre todo, en la función que cumple como apoyo al aprendizaje lector, partiendo de la psicología del comportamiento del infante.

Así mismo, Benjamin afirma que el niño no solo lee los cuentos por leerlos, sino que su lectura es una experiencia vital, en la que el poema se asume como una actitud lúdica frente al mundo, la cual hace que la imaginación ponga de presente las capacidades miméticas del niño.

Por lo tanto, el tema dela cartilla, en ambos autores, es un camino que lleva a una pedagogía ética que resalta los valores éticos de la sociedad, implementando, en el ámbito educativo, el desarrollo de capacidades, actitudes y conocimientos en niños y jóvenes.

\section{El Nuevo método de lectura y
la Cartilla Ilustrada de Rafael Pombo}

Algunos tuvimos la oportunidad de conocer a Pombo a través de Rin Rin renacuajo, La pobre viejecita, Simón el bobito y otros cuentos referentes a la literatura infantil de este poeta. Estos cuentos, fábulas y poemas resaltan el respeto, la tolerancia y la obediencia que habitan en cada verso, que fue el instrumento pedagógico y pilar principal que le ayudó a pintar la sociedad de su tiempo, a criticarla y a transformarla.

Pombo, al tener un acercamiento a la poesía infantil, recrea su espíritu lúdico y su fino sentido del humor, despertando su vocación pedagógica en la formación de las nuevas generaciones. 
Él creyó firmemente en el valor transformador del arte y el efecto estético que genera el ritmo y la musicalidad en los niños, pues el ritmo permite a los pequeños aprender a retener y a comprender, debido a que estos están más cerca de la naturaleza del infante. El poeta de los niños afirma en su Nuevo método de lectura (1984):

\section{El niño (condición providencial para su desa-} rrollo) es una bomba aspirante, no de razonamientos que lo fatigan, sino de imágenes; es esencialmente curioso, práctico y material; quiere que se le enseñe objetivamente, lo mismo que a los salvajes y a toda naturaleza primitiva. Como las imágenes son precisamente condición de la poesía, el carácter imaginativo de esta, aplicado en fábulas, emblemas o simples símiles, dobla la eficacia del ritmo poético para imprimirles cualquier lección moral, literaria o científica, que nunca olvidan más tarde, pues adquieren para ellos fuerza de axiomas, de proverbios, de experiencia anticipada (p. 280).

Este método es un conjunto de cuatro alfabetos y una cartilla ilustrada que el poeta creó con la intención de enseñar a los niños el abecedario mediante versos y dejarles lecciones de buen comportamiento.

Según Beatriz Helena Robledo², en su texto Rafael Pombo ese desconocido. Antología (2013), Pombo, "en su diario de Nueva York, probó estos alfabetos con los hijos de los amigos, convencido de las bondades del verso como vehículo para el aprendizaje” (p. 158).

2 Magíster en Literatura Hispanoamericana de la Universidad Javeriana de Bogotá; escritora e investigadora en las áreas de literatura infantil y juvenil y en procesos de formación lectora.
El Nuevo método de lectura refleja la idea de un abecedario en retahíla que describe la forma de las letras, y que ayuda al niño a reconocerlas fácilmente con la vista para poderlas combinar en sílabas, a la vez que le enseña principios morales.

La Cartilla Ilustrada con este método cumple tres funciones. La primera, enseña el alfabeto. La segunda, sensibiliza al niño con la poesía. Y la tercera, es instrucción moral. Este método muestra un conocimiento de la pedagogía, de la psicología infantil y de la moral de la época.

\section{La atención del niño se fatiga y desvía muy pronto, exige brevedad y variedad; pero sus sentidos descansan alternando el uno con el otro. De aquí que en el Nuevo método se cambie la imagen leída o contada, en su re- presentación gráfica o visible. Sus ojos da- rán tregua a los oídos, y los oídos a los ojos, y las más de las piezas deben ser cortas. El abecedario compensa su extensión con su travesura, con su movimiento objetivo; pero desde luego, irá aprendiendo por partes (Pombo, 1984, p. 280).}

Esto supone la capacidad que tienen los niños para aprender y comprender; por lo que el poeta los defiende y les llama la atención a los adultos, quienes creen que ellos solo se encierran en su mundo infantil y no muestran interés hacia lo que les rodea. Él afirma, que les gusta que sean tratados como grandes por su ambición de serlo implicando una relación niño y adulto.

La Cartilla Ilustrada materializa la pedagogía de Pestalozzi de que los niños necesitan de lo concreto y de imágenes para poder aprender. Las lecciones que posee esta cartilla están organizadas por temas, de acuerdo con lo que se quiere enseñar. Pombo organi- 
zó la cartilla de una forma aleatoria y sin una lógica fingida. Comienza con temas sobre religión, objetos concretos y áreas de conocimiento o preceptos de comportamiento. Por consiguiente, la sustentación pedagógica de Pombo está relacionada con las capacidades y con la conducta del niño. El método y la cartilla se emplean con jovialidad y travesura, creando unos versos juguetones que enseñan y que, a la vez, atrapan la atención del niño.

\section{El modelo alfabético}

¿Quieres ser hombre completo, hombre a prueba de alfabeto?

-Sé Amable, Activo, Aseado,

Bondadoso y Bienhablado, claro, más cauto en Confianzas, Sordo a Chismes, parco en Chanzas,

Libre en Digna Dependencia del Deber y la Conciencia; experto en algo Especial, Franco, Fiel, Firme, Formal, Grato, Generoso, Humano, Buen Hijo, esposo y Hermano, Ejemplo a la Ingenua Infancia; Justo, J ovial, sin J actancia; Gentil en serios hechizos, no en modas, polKas y rizos; Leal a la Ley, Laborioso, Modesto, no Malicioso, Natural, Noble en tu modo; Con Orden y Objeto en todo.

Paciente y Perseverante (Primer Prenda del triunfante);

Patriota Puro y Pacífico; Puntual, no en Parla Prolífico ni Quijote o Quejumbroso. Sé realmente Religioso

\author{
sin Superstición Salvaje, \\ Sobrio en juicio, en boca, en Traje; \\ Servicial, muy Tolerante, \\ Útil, Veraz, Vigilante, \\ Valiente, no Vengativo, \\ ni un Yo-ísta repulsivo. \\ Sé eXacto como un reloX, \\ nunca Zángano, ni Zafio; \\ Sé otro Washington, si hay dos; \\ y haZ que diga tu epitafio. \\ Honró a Padres, Patria y Dios
}

(Pombo, 1984, p. 284).

\section{Walter Benjamin y la cartilla escolar}

¿Qué pretendía nuestra maestra cuando elegía un cuento para nosotros? ¿Por qué no podíamos ser nosotros los que escogíamos el cuento? Así comienza el dualismo al que alude Benjamin (1989, p. 10) entrelos adultos que eligen los libros para los niños y la de los niños que los leen o los miran por voluntad propia.

Su pretensión abre la posibilidad de pensar las categorías de "cartilla", "infancia", "literatura infantil", "relación maestro-alumno", "escuela", propias de la Modernidad y postuladas como universales; también de pensar en unas prácticas pedagógicas escolares como "el juego", "la clase", "el recreo", que liberen a los niños de las ataduras y convicciones del adulto. Benjamin hace una crítica a la razón moderna que encierra en una "ética filistea", la fantasía y la ingenuidad de la niñez; esta ética se refleja constantemente en la literatura infantil al introducirse la obligación moral para que los niños cumplan sus deberes a cabalidad. Así mismo, él asume la infancia como 
una alegoría de un proyecto de destrucción de la subjetividad moderna y de sus realidades, de las cuales fue intérprete.

Alude Benjamin a las premisas de los libros de fábulas para la infancia que, en vez de rechazarlas como un adulto, las acogía como un niño, pero, a pesar de eso, siempre mantuvo la preocupación constante de separarse del viejo ideal pedagógico: "Sé educado, sé ordenado y sé piadoso" (p. 12). Tal pedagogía aturdía a los niños con tonos empalagosos y estetizantes con el propósito de preservarlos del mundo conflictivo de los adultos, olvidando la realidad que posee el niño, su tierna y reservada fantasía, por lo cual Benjamin se apresuró en salvar el oculto entendimiento entre niños y adultos, recurriendo a su experiencia personal, debido a que la infancia es una especie de tierra de desembarco recuperada mediante el recuerdo, al considerar que "solo puede descubrir este campo de colección —el del libro para niños-quien no ha repudiado el júbilo infantil por él” (p. 13). Lo que implica que la pasión por el pasado abre la tendencia de medirnos con el presente histórico, donde la experiencia de "repudio" a la alegría infantil involucra la relación delos viejos y olvidados libros infantiles con la autenticidad misma.

El mundo de los niños aparece como el reino donde la maldición de ser útiles se podría suspender por la marginalidad $y$, a partir de este fenómeno, Benjamin desarrolla su resistencia a "crecer", de preferir quedarse en el mundo de las hadas y de los niños que estar del lado de los adultos que crecieron de manera equivocada.

En comentarios de 1930 a una cartilla, en Escritos. La literatura infantil, los niños y los jóvenes, Benjamin resalta que "a los mayores nunca les ha faltado un pretexto pedagógico para echárselas de sabios ante los niños e imponerles sus mañas y manías del momento" (p. 125), creando en ellos la idea de convertirse en adultos y vivir sus experiencias como ellos y no como lo que son realmente. Los adultos pretenden que los niños piensen y actúen como ellos, olvidando que el niño por naturaleza juega, crea, imagina y forma su propio mundo objetivo, pequeño en lo grande. Benjamin admira la cartilla póstuma de Seidmann Freud, ilustradora y autora alemana de libros para niños, debido a que es capaz de despertar "una confianza en ellos mismos y sentido de seguridad". Por ejemplo, cuando dice: "la cartilla se reúne con el cuaderno" para "efectuar los primeros ensayos de escritura y dibujo" otorgándole "al niño confianza en sí mismo" (p. 126).

El objetivo principal de Seidmann, según Benjamin, es incorporar el quehacer infantil, para que el niño no se quede ahí en lo estipulado, sino que siga su camino sin importar la finalidad. También la autora tiene la intención de juntar el placer de escribir a la alegría de dibujar, lo que permite destruir el objetivo de la enseñanza común, basada en el catecismo y en una moralidad artificial. Esta cartilla es un método educativo, que no se dirige hacia la adquisición y al dominio de una determinada unidad didáctica, adecuada al adulto, sino que asume el carácter del niño que por naturaleza es una maravillosa aventura.

La vieja escuela, para Benjamin, "solo obliga a una continua persecución de metas, a una lucha por llegar a 'saber' lo que el omnipotente adulto exige. Por eso, obstruye las puertas que conducen hacia el saber verdadero" (p. 129). Este saber es el ejercicio inconsciente que el juego realiza como vivencia total, buscando ansiosamente 
repetición y retorno para reelaborar experiencias terroríficas y gozar una y otra vez los triunfos.

Esta cartilla se dirige al juego ensimismado del niño individual y no tanto al juego ruidoso de los grupos, porque, a través de la individualidad, el niño descubre sus capacidades miméticas quele permiten jugar a ser otro: "y detrás de una puerta, él mismo es puerta, la lleva cual máscara pesada, y como sacerdote hechicero, embrujará a todos lo que entren sin sospechar nada" (p. 89).

De igual forma, Benjamin, en Comienzos florecientes (1931), continúa destacando los libros de ilustraciones de Seidmann, en los que su encanto y su alto nivel pedagógico se resaltan cuando los libros se convierten en su mejor amigo. Con base en lo anterior, Benjamin alude a que tal vez la miseria y la inseguridad de nuestros días es el precio que tenemos que pagar para poder dedicarnos completamente al juego encantador y desencantador de las letras, donde las cartillas de Seidmann son el tesoro que debemos hallar, desenterrar y experimentar con la razón profunda del juego: la repetición y el vaivén.

Finalmente, el tema de la cartilla tiene dos miradas: la de una ética moralizante con Pombo, dondelos niños deben ser moldeados mediantela educación, que los conduce a una sana convivencia con el otro; y la de una ética no moralizante con Benjamin, que hace que el niño imagine, cree y transforme de una manera más libre y crítica el mundo que los adultos le quieren imponer. Ambos autores toman el juego y la capacidad mimética como un camino en el que los niños explotan su capacidad de transformar un objeto en otro y la de aprender de distintas maneras.

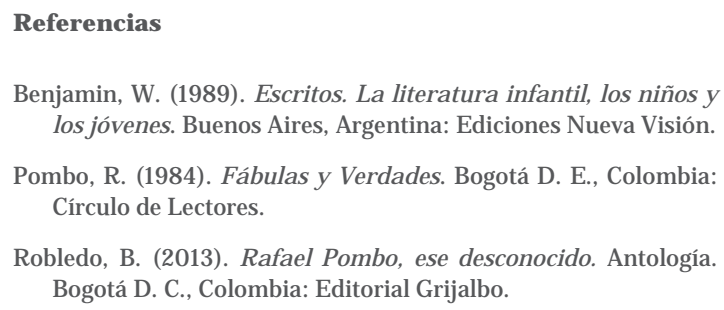




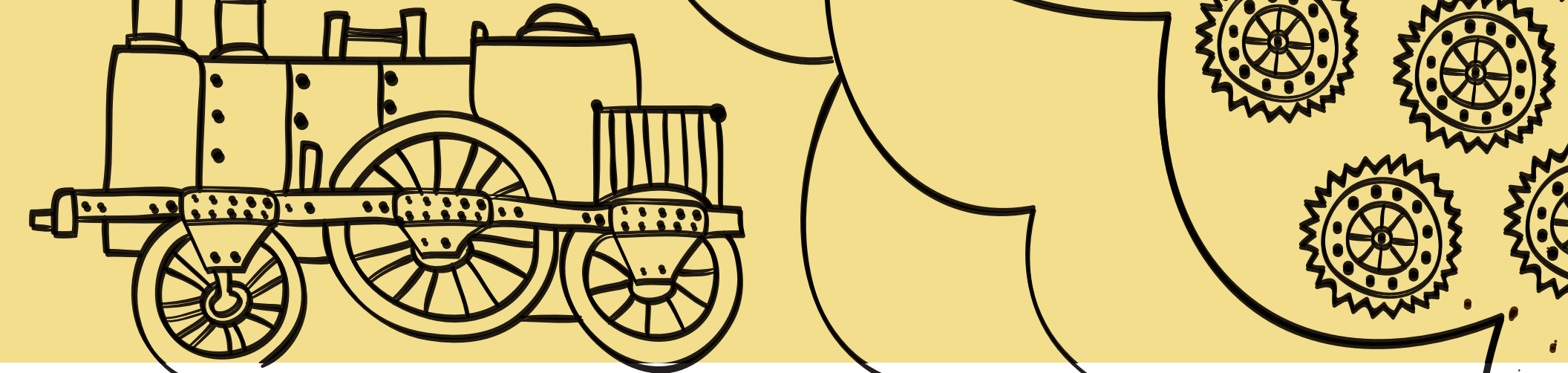

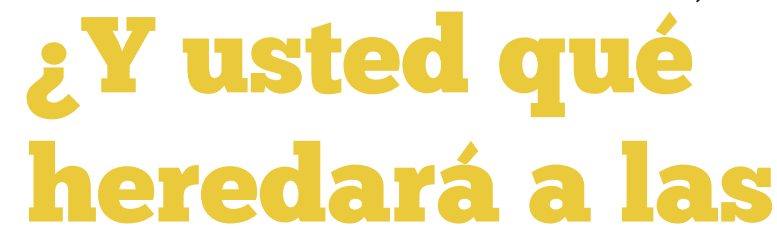

generaciones

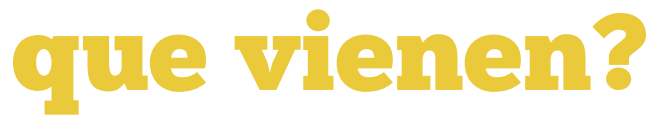

Andrea Pérez ${ }^{1}$

1 Psicóloga, candidata a magíster en Psicología Clínica y de la Familia.

uerido lector, sea esta la oportunidad para ex-

poner a usted uno de los planteamientos que han rondado de forma insistente y reiterativa por mi cabeza durante los últimos meses; a su vez, le pido el favor de que considere el presente texto como una "colcha de retazos", en donde me permitiré atentar contra la forma y abusar de las "conversaciones personales” para exponer mi punto.

Considere, a su vez, que lo que exteriorizo aquí da cuenta de un proceso personal, y que no pretendo en ningún momento elevar un manifiesto coercitivo hacia su persona, ni hacia aquello que usted considera correcto e incorrecto.

Quiero iniciar contándole una historia. Hace algún tiempo, en mi andar por la vida, encontré una mujer que, a través de sus pasos y reflexiones, sembró en mí grandes dudas, que hoy, cuando el mundo y, específicamente, nuestro país se está viendo abocado a cuestiones de tal magnitud como la paz, se han reavivado con mayor fulgor.

Deesta manera, y retomando el tema delos cambios, específicamente en nuestro territorio, me gustaría traer a colación lo escrito por Vallejos (comunicación personal, domingo 11 de septiembre de 2016), quien refiere en relación a la victoria de Nairo Quintana: “¡Colombia se está acostumbrado a ganar! Creo que ya no tenemos que hablar mal de nosotros. Somos muy buenos a nivel mundial desde donde se quiera observar. Nuestra cultura se está transformando".

Comparto su planteamiento y, a su vez, lo relaciono con la idea de que los seres humanos somos creadores de contextos, y que dichos contextos emergen 


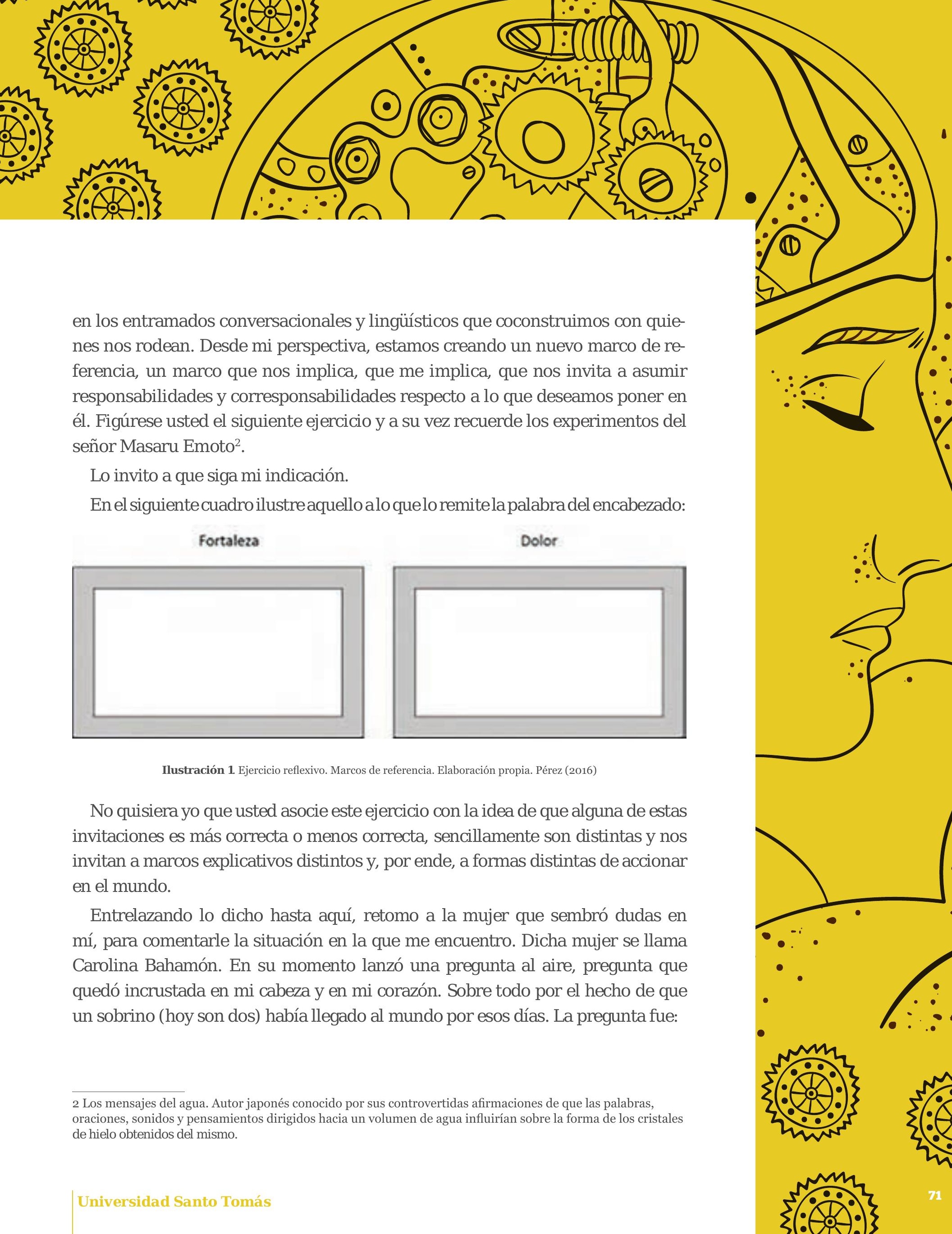


- “¿Y usted qué quiere heredarles a las generaciones que vienen luego de usted? ¿Qué quiere entregarles?” (Bahamón, comunicación personal, 2013).

En ese momento me transporté a una imagen en donde me veía a mí misma haciendo un regalo a mi sobrino, y pensaba en qué debería ir allí dentro, qué pondría yo en esa caja, qué le otorgaría a él para que transitara por el mundo.

Aún me encuentro tratando de resolver esa pregunta. Fíjese en lo siguiente:

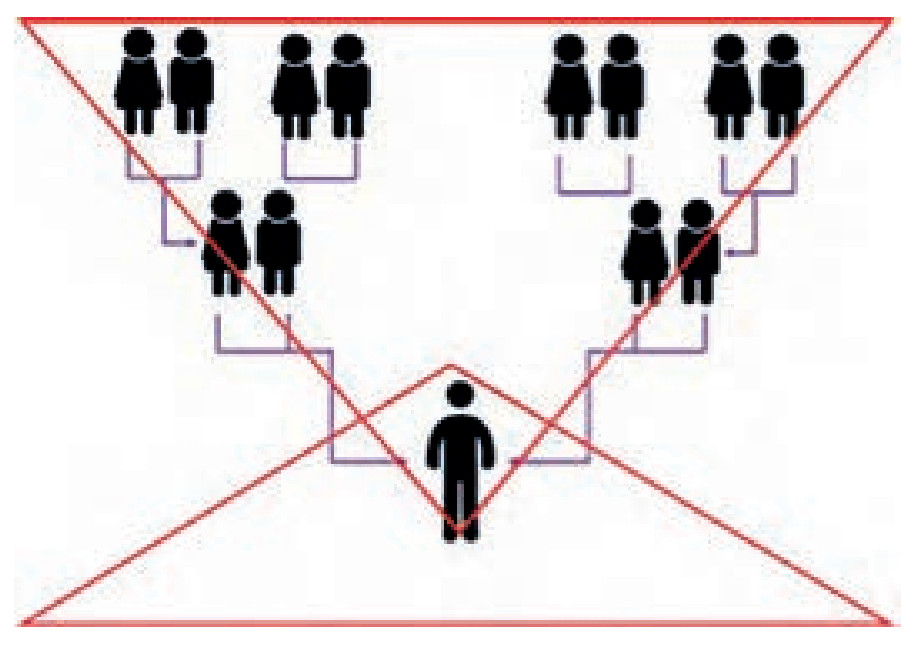

Ilustración 2. Regalos intergeneracionales. ¿Usted qué quiere regalar? Elaboración propia (Pérez, 2016)

Lo invito a que se ponga en la posición central del dibujo:

Note como - su/mi - presencia en el mundo y en lo que - construyó/construimos $\rightarrow$ La forma en cómo - usted/yo - decido/decidimos - llenar - mis/nuestros - marcos de referencia

Lo que - decido/decidimos - poner en ellos

Es sumamente relevante

No solo para - mi/su - familia

Sino para las generaciones futuras.

Puedo - verme/vernos - como un filtro, un "purificador", quizás, y me - preguntél le pregunto - : ¿Qué sí y qué no dejar pasar? ¿Qué responsabilidades implica elegir una u otra cosa? ¿Cómo afecta en definitiva a quienes - me/nos - rodean, a la construcción de sociedad, de país, de mundo?

Así pues, señor lector, pude comprender que:

SOMOS CREADORES DE REALIDADES 
Lo invito a que reflexione sobre lo siguiente:

\section{Antes}

¿Qué le fue heredado a usted? ¿Qué emociones, qué ideas, qué creencias, qué costumbres le fueron regaladas por sus ancestros? ¿Cómo esas ideas han configurado sus praxis del vivir?

\section{Después}

Siendo consciente de la importancia de su existencia y de lo que dejará a su linaje: ¿Qué quiere usted heredar a los que vienen luego, a los que lo sucederán? ¿Qué emociones, que ideas, que creencias, quiere usted dejar a sus hijos, nietos? Y, ¿cómo imagina que las mismas influirán en sus estilos de vida, en sus formas de ser hombre/mujer, familia?

Hoy (nótese la aclaración, pues es susceptible a variación), pienso que lo que les heredaría a mis sobrinos es el valor de la libertad, de que puedan elegir qué quieren poner en sus marcos, y que tengan la certeza de que estaré ahí para escucharlos, pues, tal como plantea Buenaventura (2001), "el verbo más parecido a amar es escuchar". Cuente, a su vez, con que mi apuesta va dirigida no solo a mis sobrinos, sino a quienes me rodean, a usted; así que sépase amado de mi parte.

Antes de finalizar, quisiera yo que usted se quede con la posibilidad de pensar sobre este cuestionamiento: ¿Y usted qué les heredará a las generaciones que vienen?

\section{Referencias}

Bahamón, C. (2013). Comunicación personal.

Buenaventura, N. (2001). La importancia de hablar mierda: los hilos invisibles del tejido social. Bogotá D. C., Colombia: Magisterio.

Vallejos, L. (2016). Comunicación personal.

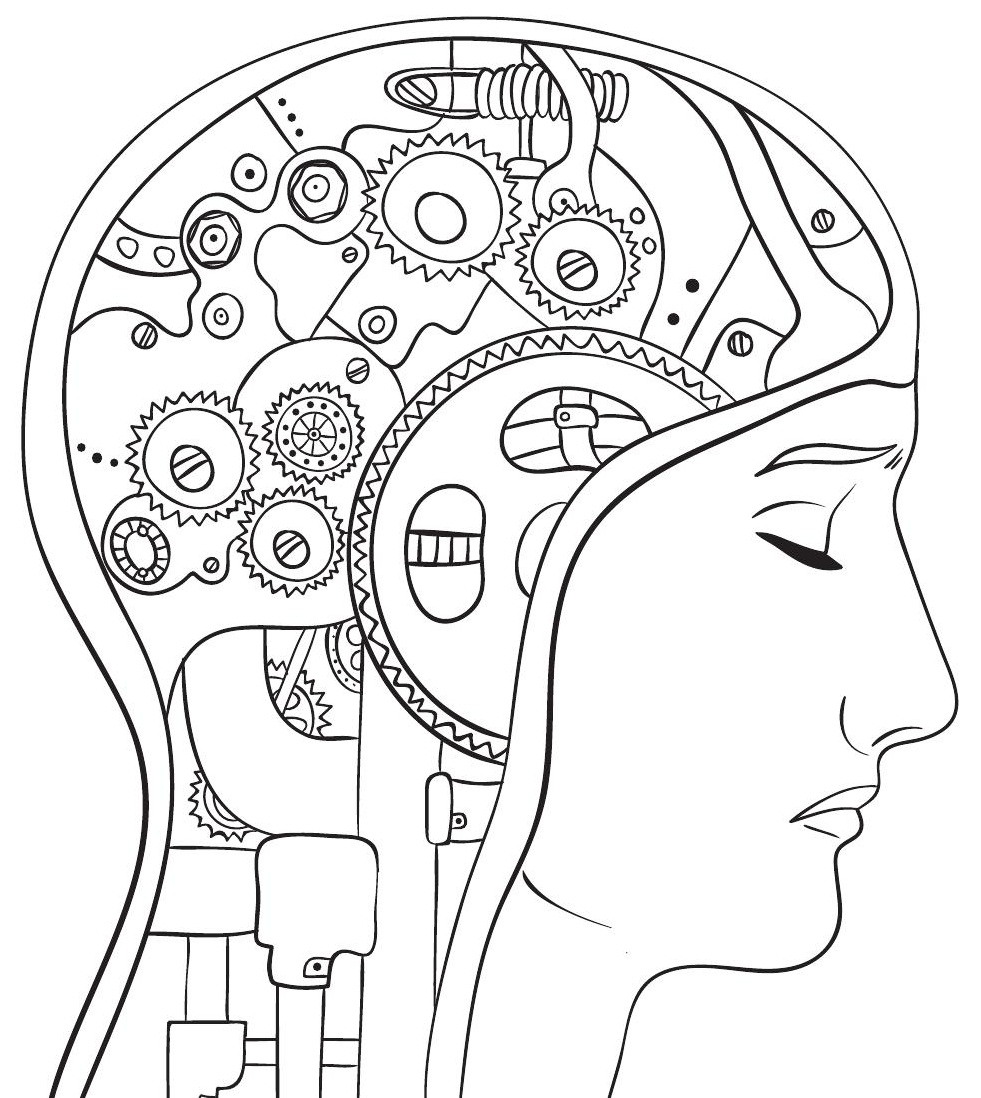




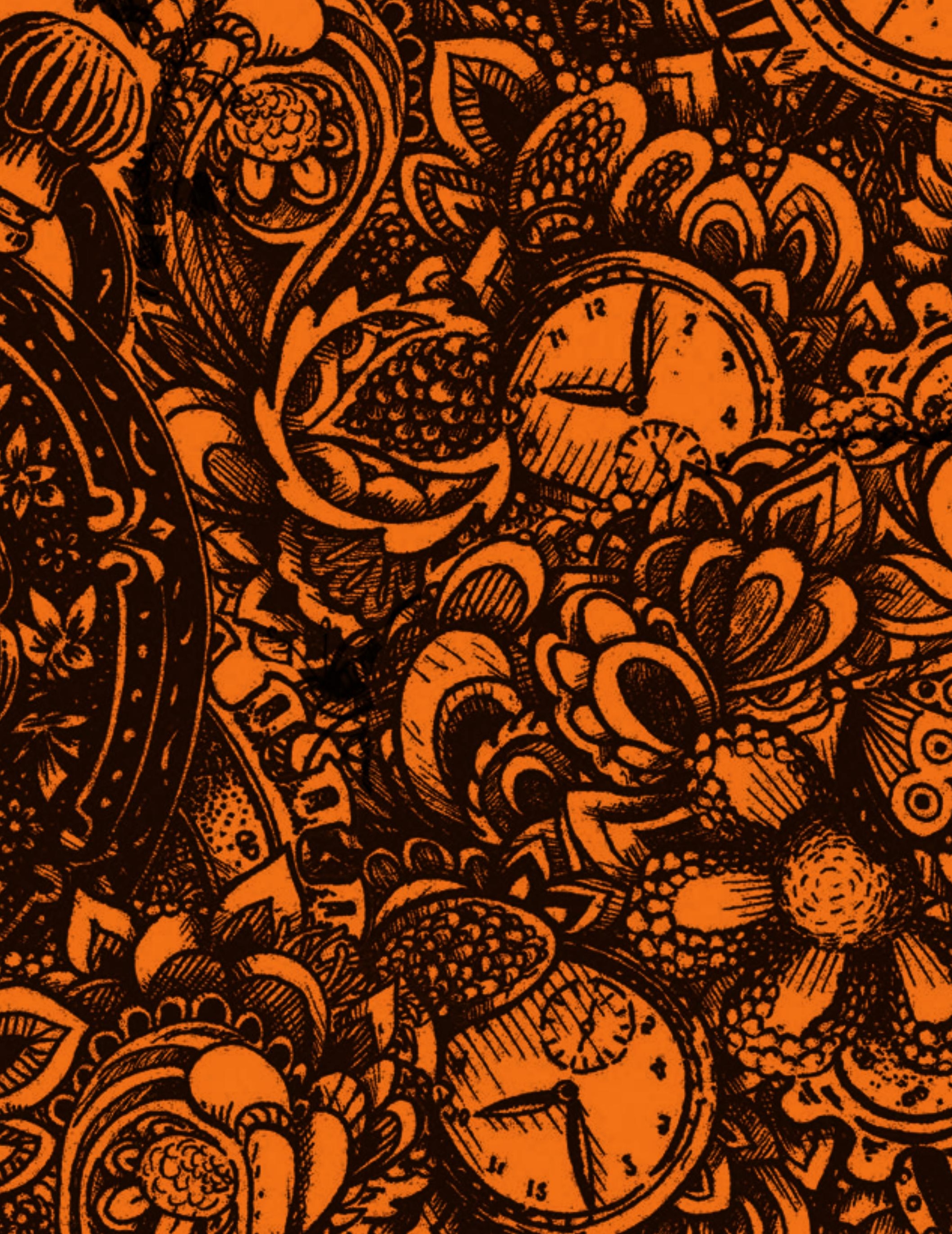




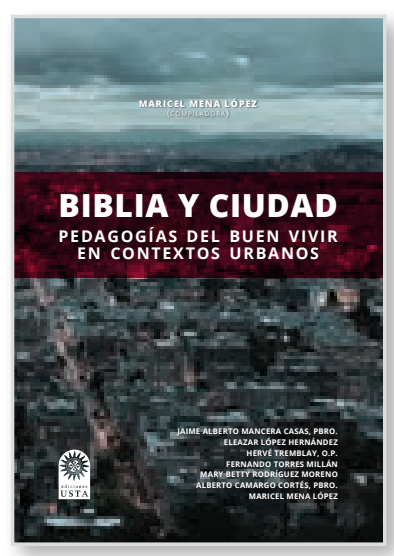

\author{
Biblia y Ciudad \\ Pedagogías del buen \\ vivir en contexros \\ Urbanos \\ Autora: Maricel \\ Mena López \\ Páginas: 190 \\ ISBN: 978-958-782-041-6 \\ Costo: 49.000 COP
}

\section{Novedades} libros

Los Evangelios testimonian que J esús no estuvo ajeno a las ciudades. En ellas desarrolló diversas actividades relacionadas con el Reino de Dios como horizonte de plenitud urbano. Por eso es tan importante ver si el mundo urbano de hoy podría ser escenario de revelaciones de lo que Dios quiere para la ciudad. ¿Son nuestras ciudades lugares de morada de Dios o lugares de ausencia y rechazo del proyecto divino para ellas? Si es lo primero, ¿qué significa eso? Y si lo que impera es lo segundo, ¿́qué nos interpela? Este estudio hace un recorrido por la Biblia buscando signos de presencia y ausencia de Dios en las ciudades procurando preguntas y reflexiones para la acción educativa y evangelizadora en los contextos urbanos de hoy.

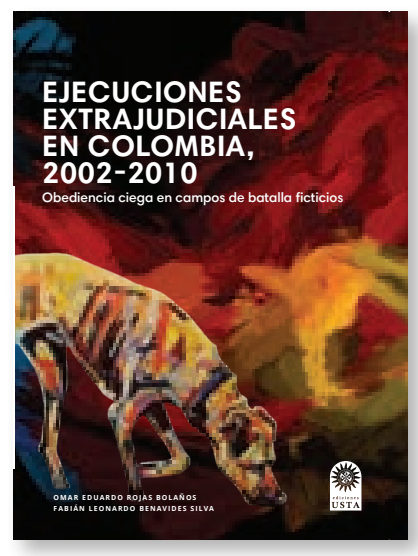

\author{
Ejecuciones \\ extrajudiciales \\ en Colombia, \\ 2002-2010 \\ Obediencia ciega \\ en campos \\ de batalla ficticios \\ Autores: Omar Eduardo \\ Rojas Bolaños Fabian Leo- \\ nardo Benavides Silva \\ Páginas: 254 \\ ISBN: 978-958-782-061-4 \\ Costo: 62.000 COP
}

4.475 jóvenes han sido reportados como falsos positivos; 5.763 fueron identificados; entidades privadas y de víctimas han recogido pruebas de 10.000 jóvenes asesinados bajo esta modalidad. Este libro es un estudio de casi una década, que le revela al lector cómo los falsos positivos no han sido producto de errores militares, ni de actuaciones aisladas de individuos pertenecientes a las Fuerzas Militares, sino que constituyen una práctica sistemática que compromete a los comandantes de brigadas, batallones y unidades tácticas. Se espera con esta investigación transdiciplinar que como sociedad no seamos indiferentes ante el sufrimiento humano de miles de seres humanos que aún no han recibido palabras de verdad ante su dolor. 


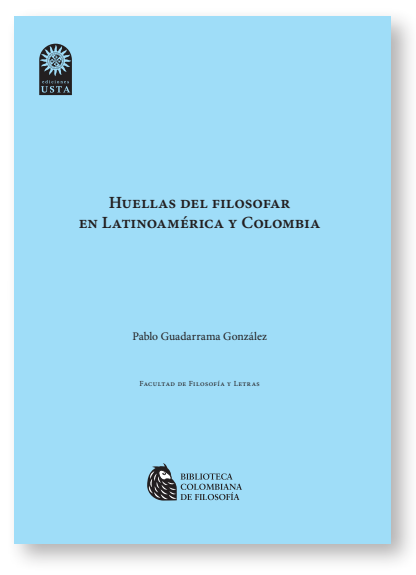

\author{
Huellas del filosofar \\ en Latinoamérica y \\ Colombia \\ Autor: Pablo Guadarrama \\ González \\ Páginas: 388 \\ ISBN: 978-958-782-047-8 \\ Costo: $63.000 \mathrm{COP}$
}

Las funciones de la filosofía, así como sus nexos epistemológicos con la ideología, la ética y la política, han sido y serán objetos permanentes de valoración por amplios sectores intelectuales, entre los cuales se encuentran algunas personalidades colombianas y latinoamericanas, estudiadas en este libro. Cada uno tuvo relaciones muy diferentes respecto a la filosofía. Sin embargo, todos ellos hicieron de la filosofía un instrumento epistémico de extraordinario valor. Los debates sobre la autenticidad de la vida filosófica de Nuestra América, al parecer superados, siempre afloran de nuevo, como para indicar que esta se debe continuar construyendo.
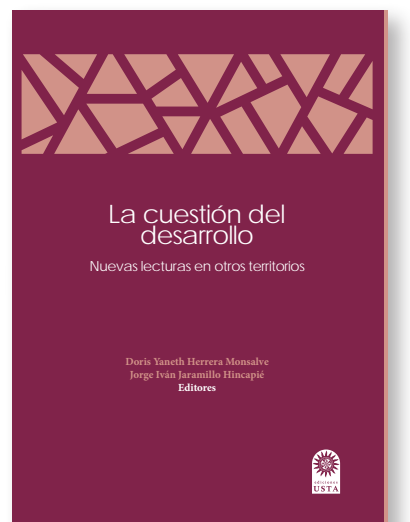

\author{
La Cuestión del \\ Desarrollo \\ Nuevas lecturas en \\ otros territorios \\ Autores: Doris Yaneth He- \\ rrera Monsalve J orge Iván \\ J aramillo Hincapié \\ Páginas: 240 \\ ISBN: 978-958-782-059-1 \\ Costo: 59.000 COP
}

Este libro compila una serie de escritos que son producto de diferentes estudios de caso, donde se radiografía el concepto de desarrollo en todas sus dimensiones y que muestra cómo, desde nuestro diario vivir, salimos del concepto de desarrollismo a ver el desarrollo propio, el de las organizaciones de base, el de las y los campesinos y el de las comunidades étnicas latinoamericanas. De igual manera se revisa el panorama de los diferentes territorios a los que los actores sociales les dan sus diferentes significados, y así se recupera el sujeto en su realidad y en su devenir.

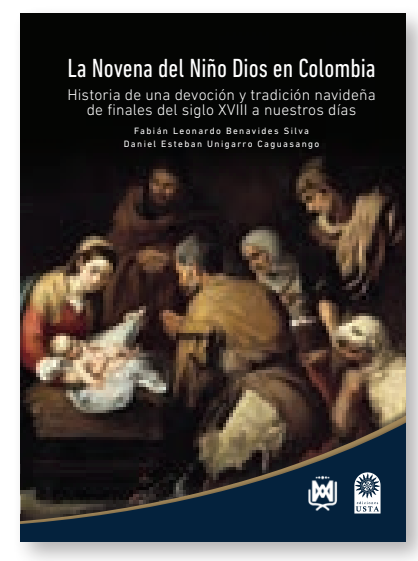

\section{La Novena del Niño \\ Dios en Colombia \\ Historia de una \\ devoción y tradicción navideña de finales del siglo XVIII a nuestros días}

Autores: Fabian Leonardo Benavides Silva, Daniel Esteban Unigarro Caguasango Páginas: 284

ISBN: 978-958-782-064-5 Costo: 39.000 COP
La Novena de Navidad no fue hecha ni modificada pensando en que su práctica permanecería vigente varios siglos, arraigando manifestaciones culturales y constituyéndose como una exitosa tradición familiar. Su formalización inicial respondió a una necesidad salvífica instituida por los preceptos cristianos que regían el siglo XVIII en los actuales territorios de Colombia y Ecuador, y su persistencia en el tiempo se debe a la capacidad inherente de acomodarse ante demandas culturales que siguen respondiendo a un esquema de creencias y valores profundamente cristianos. A través delas páginas de estelibro se presenta, entonces, la historia del origen y la difusión de esta práctica sociorreligiosa que es preciso asumir como patrimonio cultural inmaterial de los colombianos.

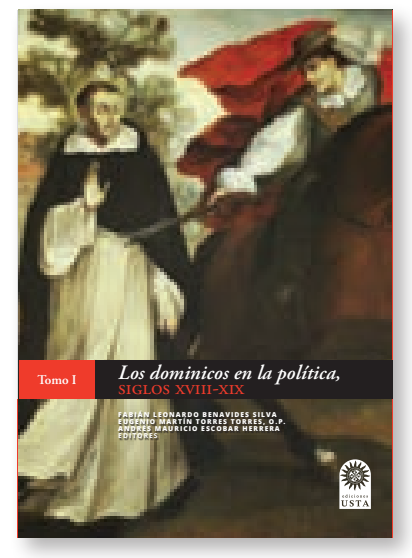
Tomo I
Los dominicos
en la política,siglos
XVIII-XIX
Autores: Fabián Leonardo
Benavides Silva, Euge-
nio Martín Torres, O. P.,
Andrés Mauricio Escobar
Herrera
Compiladora: Dulfary
Calderón Sánchez
Páginas: 328
ISBN:978-958-782-071-3
Costo: 59.000 COP

En este libro, fruto de la contribución de una amplia red de historiadores, se estudia la participación de los dominicos en diversas disyuntivas en las que, en tanto homo politicus, los frailes han estado enfrentados al ineludible papel de tomar partido en los procesos políticos asumidos por los grupos sociales en los que han estado presentes a lo largo y ancho del mundo. 
Novedades revistas

científicas

http://revistas.usta.edu.co/

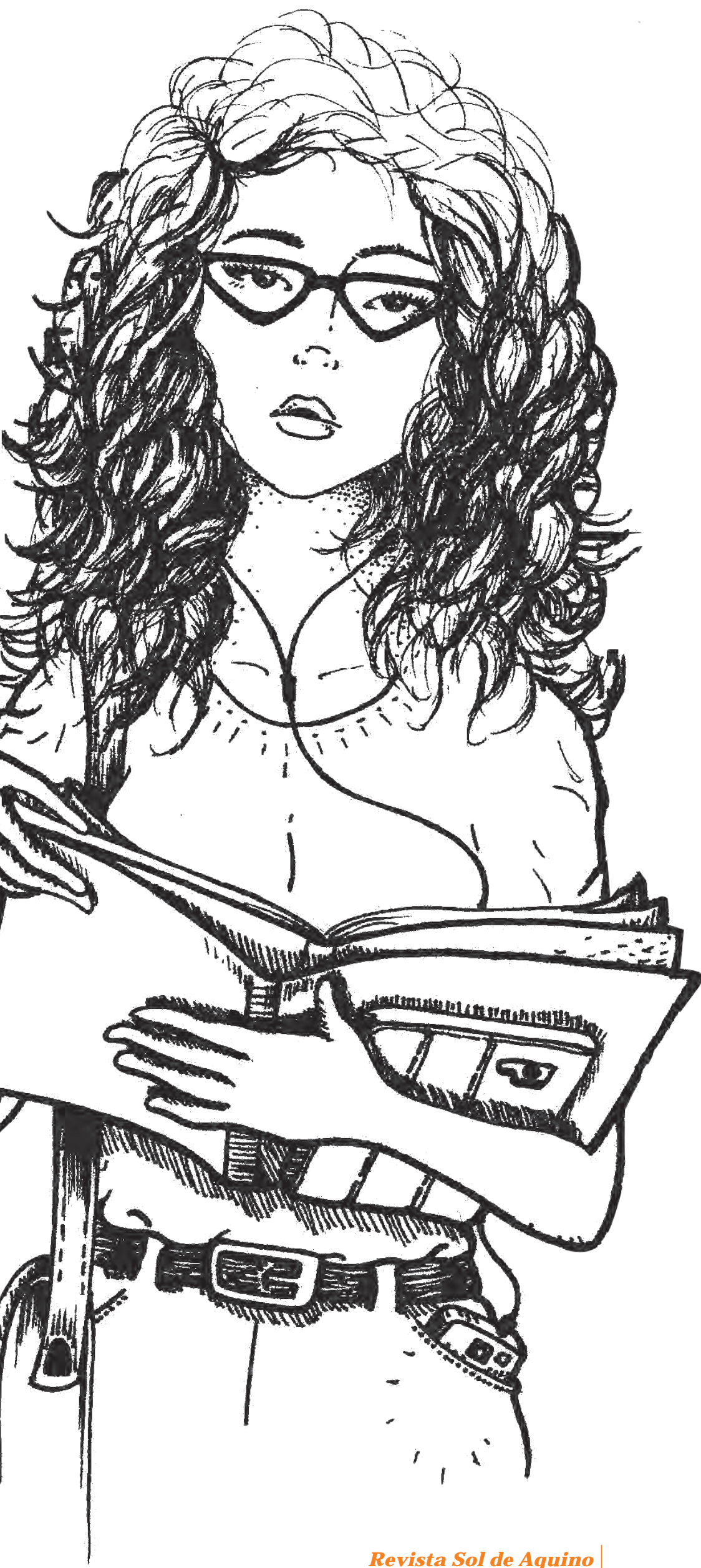




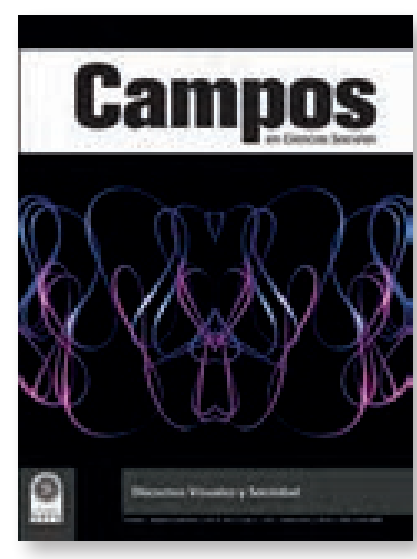

Revista Campos en Ciencias Sociales

Responsable: División de Ciencias Sociales

Sistema de indexación y bases de datos:

Fuente Académica - EBSCOHost

Web: http:// revistas.usta.edu.co/index.php/ campos/index

ISSN: 2339-3688 [Online: 2539-4363 ]

Último número: vol. 4 n.. 1

Contacto: revistacampos@usantotomas.edu.co

Artículos:

\section{Investigación}

Cine, poder e historia: la representación y construcción social del indígena en el cine ficción venezolano durante la década de los años 80

Fidel Rodríguez Velásquez

La comunicación visual a través de Pepe Mexía y Ricardo Rendón, 1915-1930

Arcadio Alexander Aldana Rincón

\section{Reflexión}

Catedrales como bibliotecas: filosofía, literatura y espiritualidad

Juan Sebastián Ballén Rodríguez

\section{Entrevista}

Los imaginarios sociales desde Armando Silva, sus avances, transformaciones y productos Camila Contreras Parada, Cristhian Uribe Mendoza, Felipe Aliaga Sáez

\section{Revisión}

Comunicación y deporte: un campo integrador para el análisis del fenómeno deportivo

\section{Lizandro Angulo Rincón}




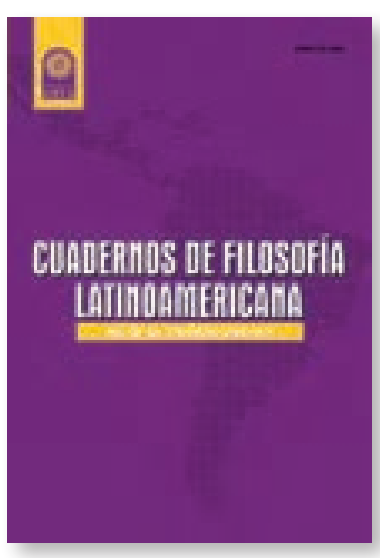

Artículos:

Fenomenología de la memoria. Superando el antagonismo entre memoria individual y memoria colectiva

J ochen Dicher

A filosofía latino-americana da superficialidade

Ronie Silveira

El concepto de cultura en los fundadores de la filosofía latinoamericana

Bernardo Nakajima

Enrique Dussel y el mito de la modernidad

Diego Fernando Camelo Perdomo

El concepto de libertad en el periodo de la Regeneración

Francisco González Granados

La filosofía realista y naturalista de John Dewey: contribuciones para una epistemología en la actualidad

Edna Maria Magalhães do Nascimento

Filosofía como forma de vida y práctica filosófica en Colombia: una aproximación al estado del arte

J ohana Páez Vigoya, Andrés Felipe Urriego Salas

Imágenes-agenciamientos y conceptos-acontecimientos en la traducción narrativa

Carolina Villada Castro

Spinoza hacia una formación sin modelos

Iván Ramón Rodríguez, Germán Ulises Bula

Hacia una visión biopragmática de la conciencia humana

Angélica María Rodríguez Ortiz

RESEÑ La fractura de Blom

Daniel Zapata

NOTICIAS Revista Latinoamericana. Colegio Internacional de Filosofía Nelson Roberto 


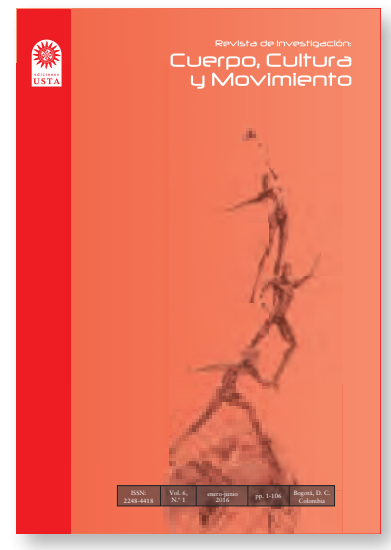

\section{Cuerpo, Cultura y Movimiento}

Responsable: Facultad de Cultura Física

Web: http:// revistas.usta.edu.co/ index.php/ rccm

ISSN: 2248-4418 [Online: 2422-474X]

Último número: vol. 6 n.ำ 1

Contacto: cuerpoculturaymovimiento@usantotomas.edu.co

Artículos:

Estudios e investigaciones

Compañía, buenos días, de pie. Construcción del cuerpo militar María Camila Otálora

Significados del cuerpo en personas con Diabetes Mellitus en la ciudad de Cali Maritza Charry Higueras

\section{Estudios de reflexión}

Corporeidade e performatividade: relações e friçõ̃es

Corporeidad y performatividad: relaciones y fricciones Paloma Bianchi

Metáforas del cuerpo: el lenguaje artístico como recurso de la memoria Josefina Dobinger-Álvarez Quioto

\section{Investigación formativa}

Validación del protocolo Five Dot Drill para medir coordinación y agilidad en jugadores de baloncesto entre los 10 y los 24 años de edad

Jonathan Andrey Martínez Rodríguez, Claudia Liliana López Albornoz, Laura Katherinne Ramírez Ramírez, Jhon Fredy Ramírez Villada, Laura Cadena 
Signos. Investigación en Sistemas de Gestión

Responsable: División de Ingenierías e Incontec

Web: http:// revistas.usta.edu.co/index.php/ signos

ISSN: 2145-1389 [Online:2463-1140]

Último número: vol. 9 n.우 1

Contacto: revistasignos@usantotomas.edu.co

Artículos:

Medición de la gestión de la calidad universitaria: revisión bibliográfica

Ximena Lucía Pedraza Nájar, Yuber Liliana Rodríguez Rojas, J avier PérezJ uárez

Enfoque de la responsabilidad social empresarial en las pymes vinculadas al sector salud de la zona suroccidente de Bogotá

J uany Amparo Camacho Kurmen, Vilma Esperanza Camacho Kurmen

Propuesta de un sistema de gestión integrado basado en NTC-ISO 9001:2015, NTC-ISO 14001:2015 y el Decreto 1072 de 2015 (capítulo 6) para una empresa de atención médica domiciliaria

Nidia Yisel Alfonso Zorro, Sonia Stella Díaz Sánchez, Florangela Gómez Hernández

Diseño de un instrumento de diagnóstico para la implementación y mejora de un sistema de gestión integrado para empresas pequeñas del sector de la construcción en Cúcuta, Norte de Santander

Evelyn Melissa Alegría Vivas, Leidy J ohanna González Pabón, Cristi Lucia Quiroga Romero

Lineamientos de un sistema integrado de gestión bajo los requisitos de NTC-ISO 9001:2015 y NTC-ISO 14001:2015 en instituciones de educación superior

Sandra J astri Losada Rodríguez, Sonia Angélica Zambrano Pineda

Impacto de la toma de conciencia en las organizaciones

Shirley Katherine Contreras Sanabria, Lethy Patricia Cruz Ramírez, Mónica J ulieth Cruz Ramírez

La Teoría de la Organización Requerida de Elliott J aques: el capítulo faltante en los libros de texto de administración

J avier Muñoz Orozco

Evaluación de la madurez de la gestión de la seguridad y salud en el trabajo: revisión de literatura

Yuber Liliana Rodríguez-Rojas, Ximena Lucía Pedraza-Nájar, J aime Apolinar Martínez Arroyo 


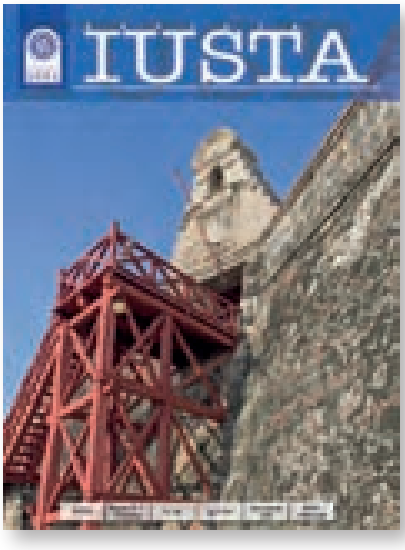

\section{IUSTA}

Responsable: Facultad de Derecho

Web: http:// revistas.usta.edu.co/index.php/iusta

ISSN: 1900-0448

Último número: $\mathrm{n} . \stackrel{0}{4} 8$

Contacto: revistasignos@usantotomas.edu.co

\section{Artículos:}

Editorial

Una nueva propiedad intelectual para el siglo -. Focos, críticas y propuestas puntuales para una futura regulación de los bienes inmateriales

Guillermo Castro Ayala

La responsabilidad civil de las entidades de certicación en Colombia

Ana Yasmin Torres Torres, Oduber Alexis Ramírez Arenas

El juez de vigilancia penitenciaria en España, como referente de la ejecuciónpenal en América Latina

Omar Huertas Díaz, Cristina Rumbo Bon, lAlicia Uribe Taborda

Estado cosmopolita en América Latina

J airo Vladimir Llano Franco, Rosa Angélica Rengifo, Lina Marcela Rojas

La fuerza vinculante de la jurisprudencia del Consejo de Estado

Sandra Mercedes Vargas Florián

Las instituciones en la administración financiera de las misiones diplomáticasde Colombia en el exterior

Iván Alejandro Trujillo Acosta

La extradición y la cooperación internacional. Falta de justicia, legitimidado incapacidad del Estado colombiano: su historia

Rodrigo Orlando Osorio Montoya

Inseguridad jurídica ante el impedimento del ejercicio de la acción pública de inconstitucionalidad dentro del proceso especial para la paz

Diana Marcela J oya Rojas, Angye Nathalia Sánchez Muñoz 
